\title{
GWAS-driven Pathway Analyses and Functional Validation Suggest GLIS1 as a Susceptibility Gene for Mitral Valve Prolapse
}

Mengyao $\mathrm{Yu}^{1,2}$, Adrien Georges ${ }^{1,2}$, Nathan R. Tucker ${ }^{3,4}$, Sergiy Kyryachenko ${ }^{1,2}$, Katelyn Toomer ${ }^{5}$, JeanJacques Schott ${ }^{6,7,8}$, Francesca N. Delling ${ }^{9}$, Patrick T. Ellinor ${ }^{3,4}$, Robert A. Levine ${ }^{10}$, Susan A. Slaugenhaupt ${ }^{11}$, Albert A. Hagège ${ }^{1,2,12}$, Christian Dina ${ }^{6,7,8}$, Xavier Jeunemaitre ${ }^{1,2,13}$, David J. Milan ${ }^{3}$, Russell A. Norris ${ }^{5}$, Nabila Bouatia-Naji ${ }^{1,2^{*}}$

${ }^{1}$ INSERM, UMR970, Paris Cardiovascular Research Center, 75015 Paris, France

${ }^{2}$ University Paris Descartes, Sorbonne Paris Cité, Faculty of Medicine, 75006 Paris, France

${ }^{3}$ Cardiovascular Research Center, Cardiology Division, Massachusetts General Hospital, Harvard Medical School, 55 Fruit Street, Boston, Massachusetts 02114 USA,

${ }^{4}$ Precision Cardiology Laboratory, The Broad Institute, Cambridge, MA 02124 USA

${ }^{5}$ Cardiovascular Developmental Biology Center, Department of Regenerative Medicine and Cell Biology, College of Medicine, Children's Research Institute, Medical University of South Carolina, 171 Ashley Avenue, Charleston, SC 29425, USA

${ }^{6}$ Inserm U1087; institut du thorax; University Hospital Nantes, France

${ }^{7}$ CNRS, UMR 6291, Nantes, France

${ }^{8}$ Université de Nantes, Nantes, France.

${ }^{9}$ Department of Medicine, Division of Cardiology, University of California, San Francisco, 94143

${ }^{10}$ Cardiac Ultrasound Laboratory, Cardiology Division, Massachusetts General Hospital, Harvard Medical School, 55 Fruit Street, Boston, Massachusetts 02114 USA

${ }^{11}$ Center for Human Genetic Research, Massachusetts General Hospital and Department of Neurology, Harvard Medical School, 185 Cambridge St., Boston, MA 02114 USA. 
12 Assistance Publique - Hôpitaux de Paris, Department of Cardiology, Hôpital Européen Georges Pompidou, 75015, Paris, France

${ }^{13}$ Assistance Publique - Hôpitaux de Paris, Department of Genetics, Hôpital Européen Georges Pompidou, 75015, Paris, France

DJM, RAN and NBN are joint senior authors for this work.

*Correspondence to nabila.bouatia-naji@inserm.fr

\section{Abstract (Abstract length: limited to 150 words)}

Nonsyndromic Mitral valve prolapse (MVP) is a common degenerative valvular heart disease with severe health consequences, including arrhythmia, heart failure and sudden death. MVP is characterized by excess extracellular matrix secretion and cellular disorganization which leads to bulky valves that are unable to co-apt properly during ventricular systole. However, the triggering mechanisms of this process are mostly unknown. Using pathway enrichment tools applied to GWAS we show that genes at risk loci are involved in biological functions relevant to cell adhesion and migration during cardiac development and in response to shear stress. Through genetic, in silico and in vivo experiments we demonstrates the presence of several genes involved in gene regulation, including GLIS1, a transcription factor that regulates Hedgehog signaling. Our findings define genetic, molecular and cellular mechanisms underlying non-syndromic MVP and implicate disrupted endothelial to mesenchymal transition and cell migration as a potential common cause to this disease.

Keywords: heart valve disease, valve development, mitral valve prolapse, GWAS based enrichment analysis 
1 Mitral valve prolapse (MVP) is a common heart valve disease with important health consequences

2 and an estimated prevalence of $2.4 \%$ in general populations $s^{1,2}$. It is defined as an abnormal mitral

3 leaflet displacement into the left atrium during systole ${ }^{3}$ and is the most common and an increasing

4 indication for surgical repair of mitral regurgitation $(\mathrm{MR})^{4,5}$. MVP is a risk factor for heart failure

5 and sudden death in community-based studies ${ }^{1,4,6}$. Prospective studies have showed that

6 asymptomatic patients with low-risk presentation (e.g., moderate MR and ejection fraction $\geq 50 \%$ )

7 can develop adverse MVP-related events, indicating wide heterogeneity in outcomes among

8 individuals ${ }^{4}$.

9 The mature valve structure represents the culmination of embryonic programs working together to create cellular and extracellular matrix (ECM) environments that can withstand the biomechanical

11 stresses of repetitive cardiac motion ${ }^{7}$. These programs include early, growth factor-mediated

12 endothelial to mesenchymal transition (EndoMT), followed by ECM organization and leaflet

13 thinning. The mature postnatal leaflet structure is organized into stratified ECM layers of dense

14 fibrous collagen in the ventricularis, a proteoglycan-rich central "spongiosa" and an elastrin-rich

15 atrialis. Endothelial cells line the valve tissue whereas fibroblastic-like ECM-producing valve

16 interstitial cells (VICs) cells make up the bulk of the valve ${ }^{7}$. In MVP, the normal layered structure

17 is lost, with expansion of myxoid-like extracellular matrix (ECM) that includes fragmented

18 collagen and elastin and overabundance of glycosaminoglycans. This renders the valve incompetent to withstand the normal physiological stresses of the beating heart and failure of

20 normal leaflet apposition with prolapse into the left atrium. The process that leads to MVP and

21 myxomatous degeneration is poorly understood. Previous reports have suggested that a potential

22 mechanism is activation of quiescent VICs to myofibroblasts. These activated cells secrete matrix

23 metalloproteinases that drive collagen and elastin fragmentation and release TGF- $\beta$ that in turn 
24 promotes further cell proliferation and myofibroblast differentiation ${ }^{7}$. However, the triggering mechanisms of myxomatous degeneration are still to be identified.

Previous familial and population genetic studies have contributed to the current understanding of

27 MVP biology. The identification of mutations in the filamin A gene $(F L N A)^{8}$ followed by research in mice $^{9}$ confirmed the role of this actin-binding protein during fetal valve development, mainly by providing stability to F-actin networks and linking them to cell membranes, which protect cells against mechanical stress ${ }^{10}$. More recently, we found that loss of function mutations in DCHS1, coding a protein from the cadherin superfamily involved in cell adhesion, cause familial MVP ${ }^{11}$. DCHS1 deficiency in VICs altered migration and cellular patterning from patients and provoked loss of cell polarity during valve development in mice and zebrafish models ${ }^{11}$. Additional clues to the etiology of MVP came through genome-wide association studies (GWAS) where we identified six risk loci that are robustly associated with genetic susceptibility to $\mathrm{MVP}^{12}$. Genetic and biological evidence supported the role of two genes; tensin 1 (TNS1), a focal adhesion protein involved in cytoskeleton organization, and a transcription factor called LIM and cysteine-rich domain $1(L M C D 1)^{12}$. However, biological functions and potential mechanisms at the remaining

39 GWAS loci remain unknown.

In this study, we hypothesize that several loci, including those not prioritized according to the

41 stringent GWAS statistical threshold ( $\mathrm{P}$-value $\left.<5 \times 10^{-8}\right)$, could contain biologically relevant genes

42 and mechanisms to MVP. We applied several computational-based analytical methods to the

43 GWAS findings to 1) highlight enriched biological mechanisms for MVP loci, 2) characterize their

44 expression pattern in tissues and 3) identify biologically pertinent genes for follow-up. Our study

45 provides evidence for the Hedgehog signaling component, GLIS1 to be involved in MVP 
46 susceptibility and provides supporting experimental validation of this gene in valve development

47 and the degenerative process.

\section{Results}

\section{Gene-set enrichment analyses for MVP loci}

51 We first applied the SNP ratio test ${ }^{13}$ (SRT) method that uses simulated datasets to estimate the

52 significance of a given pathway on the currently available GWAS data ${ }^{12}$. We analyzed $\sim 2$ million

53 SNPs that mapped within genes and found 42 nominally enriched pathways $\left(P_{\text {empirical }}<0.05\right)$

54 (Supplementary Table 1). Among the top 10 enriched pathways we found several pathways that

55 are consistent with cardiac function, including viral myocarditis $\left(P_{\text {empirical }}<0.001\right)$, hypertrophic

56 cardiomyopathy $\left(P_{\text {empirical }}<0.002\right)$, dilated cardiomyopathy $\left(P_{\text {empirical }}<0.002\right)$ and cardiac muscle

57 contraction $\left(P_{\text {empirical }}<0.005\right)$. We also noted the enrichment in the phosphatidylinositol signaling

58 system $\left(P_{\text {empirical }}<0.006\right)$, MAPK $\left(P_{\text {empirical }}<0.05\right)$ and WNT $\left(P_{\text {empirical }}<0.05\right)$ signaling that are

59 important for focal adhesion and the gap junction functions $\left(P_{\text {empirical }}<0.05\right)$.

60 We next employed i-GSEA4GWAS, which highlighted 244 pathways as significantly enriched

61 (FDR < 0.05) for MVP (Supplementary Table 2) and uses a larger source of pathways and gene

62 sets compared to SRT (BioCarta, KEGG and Gene Ontology Biological processes). The most

63 enriched pathway was BioCarta EDG-1 pathways with 26 out of 27 genes harboring associated

64 variants to MVP. Globally, enriched pathways can be functionally classified into two main groups

65 related to valve biology. The first and largest group included $28 \mathrm{GO}$ terms related to 'cytoskeleton',

66 'actin binding', 'focal adhesion', 'adhesion junction' and 'basolateral plasma membrane',

67 BioCarta gene set 'Integrin pathway' and KEGG pathway 'cell adhesion molecules'. The second 
group was related to biological gene sets involved in the development of cardiovascular system and included $21 \mathrm{GO}$ terms, notably 'heart development', 'vasculature development', 'regulation of heart contraction', 'cardiac muscle contraction', and 'angiogenesis'. Interestingly, many enriched gene sets covered functions related to gene regulation, specifically, 'transcription and regulation' (60 related pathways), e.g. 'transcription repressor activity', 'positive regulation of cell proliferation', 'positive regulation of transcription'. We note that this method also highlighted several consistent pathways with the enrichment obtained by the SRT method (e.g. dilated cardiomyopathy).

We also applied the integrative method DEPICT and used the recommended association cut-off $\left(\mathrm{P}_{\text {GWAS-value }}<10^{-5}\right)$ that identified 39 independent MVP loci harbouring 50 genes. We obtained 309 nominally enriched gene sets for MVP $(\mathrm{P}-\mathrm{value}<0.05)$ and the Pearson distance matrix provided by DEPICT defined 36 clusters from these enriched gene sets (Supplementary Table 3). The second network is linked to developmental cardiovascular phenotypes which core node is cluster 3: vasculature development. This cluster contains mainly 'abnormal blood vessel morphology', 'abnormal outflow tract development', 'failure of heart looping', 'angiogenesis', 'dorso-ventral axis formation'. Other clusters in the second network were cluster 5: 'abnormal semilunar valve morphology', cluster 9: 'TGF- $\beta$ receptor binding' and 'response to fluid shear stress', and cluster 13: 'abnormal fourth branchial arch artery morphology' and 'chromatin DNA binding'. Consistently, cluster 5, cluster 9 and cluster 13 were also significantly enriched for MVP genes and many gene sets included transcription factors as the most contributing genes (e.g LMCD1, RUNX1, FOXL1, GLIS1) (Supplementary Table 3). 


\section{Enrichment for expression in tissues and cell types}

91

92

93

94

95

96

97

98

99

100

101

102

103

104

105

106

107

108

109

110

111

112

Based on reconstituted gene-tissue matrix generated by DEPICT, we analyzed the expression profile from arrays-based human transcriptomic data and found that 21 tissues or cell types were enriched for the expression of genes at MVP risk loci. The most enriched physiological system is the cardiovascular system with five significantly enriched tissues. Connective tissue, epithelial and stem cells, specifically mesenchymal stem cells and muscle were the most enriched cell types and tissues for the expression of MVP genes (Figure 1b, Supplementary Table 4).

\section{Prioritization of GLIS1 as a novel risk locus and gene for MVP}

\section{Prioritization from contribution to enrichment analyses}

Among the loci that we included in the pathway analyses, we provide a focus on a sub-GWAS significant signal located on chromosome 1 that deserved prioritization in the light of gene function candidacy and clues from the results obtained in the enrichment analyses. We found that iGSWA4GWAS revealed GLIS1 as the best-ranked gene in six significantly (FDR $<0.05)$ and two suggestively $(\mathrm{FDR}<0.25, \mathrm{P}$-value $<0.05)$ enriched gene sets, all related to regulation of transcription (Supplementary Table 5). Interestingly, Hh signaling pathway (from KEGG) was also associated with MVP (P-value=0.015, FDR=0.054, Supplementary Table 2). Although GLIS1 is not reported as part of this pathway according to KEGG, several other genes from this pathway contain significantly associated variants with MVP (e.g WTN5B, BMP6, HHIP, SHH, GLI2 and GLI3 Supplementary Table 6). According to the DEPICT analysis, we found that GLISI significantly contributes to the enrichment of several tissues and cell types namely the connective tissue (GLIS1 Z-score=2.3), connective tissue cells $($ GLIS1 Z-score=2.8) and mesenchymal stem cells $(Z$-score=2.3) (Supplementary Table 4). Of note, GLIS1 is the most contributing MVP gene 
$113(\mathrm{Z}$-score $=6.2)$ to suggestive enrichments $(\mathrm{P}$-value $=0.13, \mathrm{FDR}>=0.20)$ of two cardiovascular 114 system tissues (aortic valve and heart valves, Supplementary Table 4).

\section{Genetic association at the GLIS1 locus}

117 The association context at the GLIS1 locus is presented in Figure 2a. The most associated SNP 118 with MVP is rs 1879734 and locates in the first intron $\left(\mathrm{OR}=1.30, \mathrm{P}\right.$-value $=7.1 \times 10^{-6}$, risk allele: $\mathrm{T}$, 119 Freq: 0.28) (Supplementary Table 7). Follow-up of this SNP in four case control studies provided 120 positive replication in the two largest studies, consistent direction of effect in all studies and no 121 evidence for heterogeneity $\left(\mathrm{OR}_{\mathrm{all}}=1.23, \mathrm{P}_{\mathrm{effect}}=1.2 \times 10^{-7}, \mathrm{P}_{\text {Heterogeneity }}=0.41\right)($ Supplementary Table $1227)$.

123 We performed functional annotation for 111 SNPs in moderate LD with $r s 18797434\left(r^{2}>0.5\right)$ that 124 showed nominal association with MVP $\left(\mathrm{P}_{\mathrm{GWAS}}-\mathrm{value}<0.05\right)$ and all mapped to introns 1 and 2 in 125 GLIS1(Supplementary Table 8). We found that 47 SNPs locate in DNase Hypersensitive region 126 (DNASEV) in diverse normal tissues and 16 locate in transcription factor binding sites (TFBS). 127 rs1879734 is located in a TFBS for endothelial transcription factor GATA2. Interestingly, we 128 observed that rs12091931, which locates in DNASEV in non-pigmented ciliary epithelial cells, is in TFBSs for JUND, MAFF, MAFK, UBTF, MAZ, CTCF, ZBTB7A, TBP (Supplementary Table

130 8). Hereafter, the examination of the GTEx eQTL portal indicates that 58 SNPs, including the lead 131 SNP rs1879734 were potential nominal eQTLs $(\mathrm{P}<0.05)$ for GLIS1 in heart atrial appendage tissue 132 ( $\mathrm{N}=264)$. The most significant eQTL for GLIS1 is rs2950241 ( $\mathrm{P}$-value $=9 \times 10^{-3}$ ), which is highly 133 correlated to rs1879734 ( $\mathrm{r}^{2}=0.96$, Hapmap CEU).

134 The examination of histone marks (Figue $2 \mathrm{~b}$ ) in mesenchymal stem cell originated from H1-hESC 135 shows the presence of robust enhancer mark (H3K4me1) in the vicinity of rs1879734. In H1-hESC, 

and adult time points (Figure 3). During embryonic development, Glis1 is expressed

148 predominantly in nuclei of endothelial cells of the valves as well as the VICs. As the valves mature important role for Glis1 in regulating valve morphogenesis during early development.

strong signal of enhancer mark (H3K4me1) was presented at rs4927029, rs12097598, rs11206201, rs55786134, rs17109178. However, none of the 111 SNPs showed signals of histone marks in heart related tissue/cell types (pulmonary artery endothelial cell, cardiac mesoderm, heart left ventricle) (Figue 2b). In silico 4C experiment using four cell types including THP-1 ${ }^{14}$, HUVEC ${ }^{15}$, H1-hESC ${ }^{16}$ and NHEK $^{15}$ (Supplementary Figure 1) showed that the associated SNPs at this locus physically interact only with GLIS1 regulatory sequences suggesting it is the potential target and causal gene at this locus.

\section{Expression during heart development in mouse}

To study the pattern of expression of GLIS1 during valve development, we performed immunohistochemistry (IHC) experiments of the mouse ortholog, Glis1 during embryonic, foetal during foetal gestation, Glis1 is retained in a subset of endocardial and interstitial cells. By 6months of age, Glis1 is much weaker in the valve leaflet with only scant cytoplasmic staining in endocardial cells. Weaker expression of Glis1 could be detected in the myocytes, epicardium and endocardium of the ventricular myocardium. These data show that Glis1 is embryonically expressed and that levels of this protein are rarely detected in the postnatal mouse, suggesting an 


\section{Knockdown of Glis-1 cause atrioventricular regurgitation in zebrafish}

158 To analyse the potential effects of GLIS-1 on valvular development and function, we chose to

159 investigate its expression in the zebrafish. Due to genome duplication, zebrafish are predicted to

160 have two orthologues of GLIS-1, glisla and glis1b. We designed antisense morpholino

161 oligonucleotides to target splice junctions in each with aims of rendering the transcript non-

162 functional. Knockdown of glis $1 a$ was $65 \%$ efficient at 72 hours post fertilization, but had no

163 discernible effect on atrioventricular valve function (Supplemental Figure 2). Knockdown of

164 glis $1 b$ at 72 hours post fertilization was robust but slightly less efficient $(37.3 \%$ and $36.5 \%$

165 reduction Figure 4a, b) and had minimal effects on the overt morphology of the developing embryo

166 (Figure 4c). However, this knockdown resulted in a significant increase in the incidence of severe

167 atrioventricular regurgitation when compared to controls. This increase was observed with two

168 independently injected morpholinos with a combined fold increase of $1.6(\mathrm{P}=0.01)$ (Figure $4 \mathrm{~d})$.

\section{Discussion}

172 Our study supports that MVP genes are predominantly part of gene sets involved in cardiac 173 development, the regulation of cell adherence and migration, and the regulation of cytoskeleton

174 biology, focal adhesion and the interaction with the extracellular matrix. We also show that MVP

175 genes are highly expressed in the cardiovascular system, connective and mesenchymal tissues.

176 These genes are often regulatory genes expressed in the nucleus, as it is the case for GLIS1. Our

177 findings suggest that this Hedgehog signalling related transcription factor is expressed in the 
178

179

180

181

182

183

184

185

186

187

188

189

190

191

192

193

194

195

196

197

198

199

nucleus of developing mitral valves in mouse and is required for atrioventricular development and function in zebrafish.

The application of three gene set enrichment tools to MVP GWAS data, using overall different computational methods and diverse databases provided overall consistent enrichments and an unprecedented resource to understand mitral valve biology. One of the most significantly enriched gene sets for MVP genes according to the i-GSEA4GWAS method is the endothelial differentiation gene (EDG-1) pathway where 26 out of 27 genes are associated with MVP. EDG1 is a key signalling pathway for actin assembly and lamellipodia formation through the activation of integrins alpha $\mathrm{V}$ (ITGAV) and beta 3 (ITGB3) via RAS homolog gene family member A (RHOA). Edg1 knockout mice show embryonic haemorrhage leading to intrauterine death due to incomplete vascular maturation and defects in SPP-induced migration response ${ }^{17}$, which are important steps prior to valve sculpting at the embryonic stages. Cardiomyocyte specific knockout of EDG1 (alias S1PR1 for sphingosine 1-phosphate receptor-1) resulted in ventricular noncompaction and ventricular septal defects at 18.5 days post conception in mice, supporting a crucial role for this pathway in cardiac development ${ }^{18}$. Whether genes from EDG1 signalling are specifically important for valve development needs future examination. In support of this hypothesis is the reported interaction during lamellipodia formations of S1PR1 and Filamin $\mathrm{A}^{19}$, which gene is reported to be mutated in familial forms of $\mathrm{MVP}^{20}$. Many additional gene sets enriched for MVP loci are also involved in cardiac development or disease. These enrichments suggest critical roles for genetic variability near genes acting during early heart development that require important cytoskeleton remodelling and organization for cell migration during the endothelial-to-mesenchymal transition (EndoMT). 
200

201

202

203

204

205

206

207

208

209

210

211

212

213

214

215

216

217

218

219

220

221

222

Our enrichment analyses also pointed to various pathways and gene sets whose link to valve disease is currently in its infancy. For instance, our analyses indicate an enrichment for gene sets in the immune system and phagosome pathways in MVP disease. The contention that the immune system may be involved in MVP is further supported by work from our group as well as others ${ }^{9,21}$. Additionally, the phagosome pathway has recently been reported as dysregulated in human myxomatous mitral valves compared with healthy valves ${ }^{22}$ and high activity of autophagosomes are present during cardiac development ${ }^{23}$. In addition, the knockdown of autophagy genes caused defects in cardiac looping and aberrant valve development as the results of ectopic expression of critical TF involved in heart development, mainly foxn4, tbx5 and tbx $2^{23}$.

We report several top contributing genes at MVP loci to be transcription factors, especially to gene sets related to cardiovascular development. Consistently, we report enrichment for the protein localization to nuclear gene sets. Here, we followed-up specifically GLIS1, which was one of the top associated SNPs with MVP that we confirmed as a potential sub-GWAS risk locus for MVP. In addition to the expression in developing heart valves, GLIS1 was the most significantly contributing gene to the enrichment of several gene sets related to the regulation of transcription. Little is known about GLIS1 function in connection with valve biology. We found that GLIS1 is expressed during developing valves in mouse valve endocardial and interstitial cells, suggesting for the first time its potential regulatory role during heart development. There is evidence for Glis1 to markedly increase the efficiency of generating induced pluripotent stem cells (iPSC) from

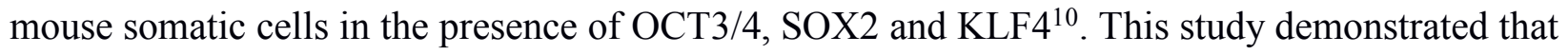
GLIS1 directly interacts with KLF4 and induces the expression of Forkhead box genes, especially FOXA2 and several WNT genes to enhance mesenchymal to epithelial transition, a mechanism required for cell reprogramming ${ }^{24}$. The Hh signalling regulates both FOXA2 and WNT genes and 
223 its suggestive enrichment in our MVP GWAS involves for the first time in valve disease this

224 important pathway for cell migration and morphogenesis organisation during heart development ${ }^{25}$.

225 The Hh signalling induces EndoMT, through the up-regulation of NOTCH and TGF- $ß$ signalling ${ }^{26}$

226 and is coordinated by primary cilia during cell migration and heart morphogenesis ${ }^{25}$. The

227 contributing genes to the enrichment of the Hh signalling pathway included BMP2 that harbours

228 causative mutations for cardiac anomalies ${ }^{27}$ and $B M P 4$ that is required for outflow-tract septation ${ }^{28}$.

229 Interestingly, a common variant in the also associated $W N T 8 A$, member of the WNT genes family

230 is associated with atrial fibrillation ${ }^{29}$ and was previously shown to be regulated by GLIS $1^{10}$.

231 This work presents however several limitations. One critical step when performing enrichment

232 analyses in GWAS loci is the attribution of variants to genes. The pathway analyses of i-

233 GWSEA4GWAS and DEPICT rely on SNPs mapped to genes using physical distance and LD

234 block information. This have limited the number of genes analysed at risk loci and excluded more

235 distant genes of interest. There is established evidence in favour of the functional role of distant

236 long-range regulatory variants in predisposition to complex disease ${ }^{30}$. In most cases, associated

237 variants in GWAS loci are less likely to regulate the closest genes and be hundreds of kilobases

238 away from culprit genes. This limitation explains the absence from the prioritization list generated

239 by DEPICT of TNS1, a focal adhesion protein-coding gene that we have previously incriminated

240 in MVP through genetic and functional investigation ${ }^{12}$.

241 In conclusion, our pathway investigation supports that genes near MVP associated loci are

242 involved in biological functions relevant to cell adhesion and migration during cardiac

243 development and in response to shear stress, and highlight the importance of regulatory

244 mechanisms. Our study also provides genetic in silico and in vivo functional exploration of GLIS1,

245 a transcription factor that regulate members of the Hh signalling and implicates this important 
246 biological mechanism for EndoMT and cell migration during heart development in valve

247 myxomatous disease.

\section{Methods}

\section{GWAS Study populations}

250 The clinical characteristics of MVP patients, controls and GWAS methods have been previously

251 described $^{12}$. Briefly, we applied pathway-based methods to a meta-analysis of two GWAS

252 conducted in 953 patients from MVP-France and 1566 controls and 489 from MVP-Nantes and

253873 controls $^{12}$. Replication was performed in four case-control studies (totalling 1,422 European

254 MVP patients and 6,779 controls) as previously described ${ }^{12}$. Local ethics committees approved all

255 studies, and all patients and controls provided written informed consent.

256 The input data was 6.6 million $(\mathrm{M})$ genotyped or imputed SNPs (MAF > 0.01) and used either

257 SNPTEST ${ }^{31}$ (imputed) or PLINK ${ }^{32}$ (directly genotyped) to perform the association test. Regional

258 association plot at GLIS1 locus was created using LocusZoom ${ }^{33}$.

\section{Pathway analyses}

261 SNP ratio test $(S R T)$

262 SRT is a tool that calculates an empirical P-value by comparing the proportion of significant SNPs

263 ( PWAS-value $\left._{\mathrm{G}}<0.05\right)$ in the original GWAS to randomized GWAS for the phenotype of cases and 264 controls $^{13}$. SRT tests enrichment using the KEGG pathways catalog and then allocates SNPs to 265 genes using physical position and does not consider intergenic SNPs. Approximately 2 million

266 GWAS SNPs were mapped to the reformed KEGG pathways and gene sets. We first generated 2671000 simulated alternative phenotypes for individuals tested and ran the association analyses using 
$268 \mathrm{PLINK}^{32}$. The empirical P-value for a given pathway is defined by $P_{\text {empirical }}=(s+1) /(N+1)$, where

$269 s$ is the number of times that a simulated ratio significant to non-significant was greater than or

270 equal to the ratio obtained from the GWAS computed with real phenotypes, $N$ is the total number

271 of simulations (here $N=1000$ ) and enrichment was higher when $\mathrm{P}$ was small .We set significance

272 to $P$-value $<0.05$ in simulated and real GWAS, and for the empirical $\mathrm{P}$-value.

273 Gene set enrichment analyses using i-GSEA4GWAS

274 i-GSEA4GWAS v2 uses SNPs and their corresponding P-values from GWAS results as input ${ }^{34,35}$.

275 All SNPs from the GWAS meta-analysis were used and were mapped to genes if they are

276 exonic/intronic or to the closest genes if they are within $20 \mathrm{~Kb}$ upstream/downstream a gene. Of

277 the $6.6 \mathrm{M}$ tested, $4.3 \mathrm{M}$ variants were mapped to 21,167 different genes and then genes were

278 attributed to pathways and/or gene sets using BioCarta, KEGG, and GO terms from MSigDB v4.0.

279 Only GO terms with experimental evidence (codes IDA IPI, IMP IGI, IEP), computational analysis

280 evidence codes (ISS) and author evidence statement (TAS) were taken into account. In total, 936

281 gene sets contributed to calculate the significant proportion based enrichment score (SPES). We

282 used the authors' recommendation to consider pathways/gene sets with $\mathrm{FDR}<0.25$ as suggestively

283 associated with disease and $\mathrm{FDR}<0.05$ as high confidence or statistically significant enrichment.

284 Integrative analyses using DEPICT

285 Data-driven expression prioritized integration for complex traits (DEPICT) (version rel194) is an

286 integrative tool that utilizes diverse sources to predict reconstituted gene sets specific to each meta-

287 analysis of $\mathrm{GWAS}^{36}$. DEPICT uses predefined gene sets including protein-protein interactions

288 database, Mouse Genetics Initiative database, Reactome, KEGG and GO terms. It also uses a co-

289 regulation data frame downloaded from the Gene Expression Omnibus (GEO) database including

290 human and rodent expression microarrays (total arrays 77,840, including 37,427 generated in 
291 human tissues). This information was used to perform gene prioritization at loci, gene set

292 enrichment analyses, and provide genes expression profiles in 209 tissues or cell types defined by

293 Medical Subject Heading (MeSH). Input of DEPICT is a list of the most significantly associated

294 SNPs $\left(\mathrm{P}_{\mathrm{GWAS}}-\mathrm{value}<1 \times 10^{-5}\right)$ after LD pruning. Loci were mapped to genes using $\operatorname{LD}\left(\mathrm{r}^{2}>0.5\right)$.

295 Genes where several SNPs map are counted once. To group overlapping gene sets, pairwise

296 Pearson's correlation coefficient of all enriched gene sets was calculated and the Affinity

297 Propagation (AP) method m,37 $^{36,3}$ used to cluster gene sets that are highly correlated to

298 automatically define independent clusters based on the Pearson distance matrix. We set

299 significance for enrichment to $\mathrm{P}$-value $<0.05$, given that no gene sets reached an FDR $<0.05$.

\section{Variants Annotation}

302 We used the UCSC genome browser tool Variant Annotation Integrator (VAI) to annotate SNPs 303 at the GLIS1 locus, and indicate if SNPs were located on DNase Hypersensitive region or 304 transcription factor binding site generated by ENCODE ${ }^{38}$. Tissue specific expression quantitative 305 trait loci (eQTL) annotation was extracted from GETx portal (https://www.gtexportal.org/home/, 306 Release V7, dbGaP Accession phs000424.v7.p2). Annotation of the 111 selected SNPs by Human 307 ChIP-Seq (markers: H3k4ME1 and H3k4ME3) and DNase-Seq were downloaded from ENCODE 308 (https://www.encodeproject.org/) and visualized by Integrated Genome Browser (IGB) ${ }^{39}$. In the 309 absence of valvular cells in this database, selected tissues/cells used in this analyses are 310 mesenchymal stem cell originated from $\mathrm{H} 1-\mathrm{hESC}^{40}, \mathrm{H} 1-\mathrm{hESC}{ }^{40}$, pulmonary artery endothelial 311 cell $^{41}$, cardiac mesoderm ${ }^{41}$ and heart left ventricle ${ }^{40}$. Accession numbers of those files are

312 (respectively): ENCFF152YQG (H3K4me1), ENCFF712CJP (H3K4me3), ENCFF623ZAW 313 (H3K4me3), ENCFF593OAZ (H3K4me1), ENCFF719ZEX (DNase-seq), ENCFF591TLE 
(H3K4me3), ENCFF213FJN (DNase-seq), ENCFF094USN (DNase-seq), ENCFF254JZR

315 (DNase-seq). The annotation of the GLIS1 region used the Hi-C data from four cell types including THP-1 ${ }^{14}$, HUVEC $^{15}, \mathrm{H} 1-\mathrm{hESC}^{16}$ and NHEK ${ }^{15}$ from ENCODE, all visualized by IGB.

\section{Protein detection in mouse embryos and adult hearts}

319 In all IHC experiments, 5-min antigen retrieval was performed with VectaStain in a pressure

321 heavy chain (Developmental Hybridoma Banks, MF20). Primary antibodies were used at a 1:100

322 dilution; Hoechst 33342 (nuclear stain) was used at a 1:10,000 dilution. Appropriate secondary

323 antibodies were used for detection. Three time points were used in IHC: (i) completion of the

324 endothelial-to-mesenchymal transition (EndoMT; embryonic day (E) 13.5), (ii) valve sculpting 325 and elongation (E17.5) and (iii) achievement of the mature adult form (at 9 months).

\section{Zebrafish experiments}

Zebrafish experiments were performed in accordance with approved Institutional Animal Care and

329 Use Committee (IACUC) protocols. Zebrafish of the Tu-AB strain were reared according to standard techniques. Morpholinos were designed against the two zebrafish orthologues of GLIS1: 
bioRxiv preprint doi: https://doi.org/10.1101/433268; this version posted October 2, 2018. The copyright holder for this preprint (which was not certified by peer review) is the author/funder, who has granted bioRxiv a license to display the preprint in perpetuity. It is made available under aCC-BY-NC-ND 4.0 International license.

335 non-targeting morpholino. Analysis of atrioventricular regurgitation was performed at 72 hours

336 post fertilization as described ${ }^{12}$. 


\section{REFERENCES}

1 Freed, L. A. et al. Prevalence and clinical outcome of mitral-valve prolapse. New England Journal of Medicine 341, 1-7 (1999).

2 Delling, F. N. \& Vasan, R. S. Epidemiology and pathophysiology of mitral valve prolapse: new insights into disease progression, genetics, and molecular basis. Circulation 129, 2158-2170 (2014).

3 Guy, T. S. \& Hill, A. C. Mitral valve prolapse. Annual review of medicine 63, 277-292 (2012).

4 Avierinos, J. et al. Natural history of asymptomatic mitral valve prolapse in the community. Circulation 106, 1355-1361 (2002).

5 Gammie, J. S. et al. Isolated Mitral Valve Surgery: The Society of Thoracic Surgeons Adult Cardiac Surgery Database Analysis. Ann Thorac Surg 106, 716-727, doi:10.1016/j.athoracsur.2018.03.086 (2018).

6 Freed, L. A. et al. Mitral valve prolapse in the general population: the benign nature of echocardiographic features in the Framingham Heart Study. J Am Coll Cardiol 40, 12981304 (2002).

7 Levine, R. A. et al. Mitral valve disease--morphology and mechanisms. Nat Rev Cardiol 12, 689-710 (2015).

8 Kyndt, F. et al. Mutations in the gene encoding filamin A as a cause for familial cardiac valvular dystrophy. Circulation 115, 40-49 (2007).

9 Sauls, K. et al. Developmental basis for filamin-A-associated myxomatous mitral valve disease. Cardiovascular research 96, 109-119 (2012).

10 Maekawa, M. et al. Direct reprogramming of somatic cells is promoted by maternal transcription factor Glis1. Nature 474, 225 (2011).

11 Durst, R. et al. Mutations in DCHS1 cause mitral valve prolapse. Nature 525, 109-113 (2015).

12 Dina, C. et al. Genetic association analyses highlight biological pathways underlying mitral valve prolapse. Nat Genet 47, 1206-1211 (2015).

13 O'dushlaine, C. et al. The SNP ratio test: pathway analysis of genome-wide association datasets. Bioinformatics 25, 2762-2763 (2009).

14 Phanstiel, D. H. et al. Static and Dynamic DNA Loops form AP-1-Bound Activation Hubs during Macrophage Development. Molecular cell 67, 1037-1048 (2017).

15 Rao, S. S. P. et al. A 3D map of the human genome at kilobase resolution reveals principles of chromatin looping. Cell 159, 1665-1680 (2014).

16 Dixon, J. R. et al. Topological domains in mammalian genomes identified by analysis of chromatin interactions. Nature 485, 376-380, doi:10.1038/nature11082 (2012).

17 Liu, Y. et al. Edg-1, the G protein-coupled receptor for sphingosine-1-phosphate, is essential for vascular maturation. J Clin Invest 106, 951-961, doi:10.1172/JCI10905 (2000).

18 Clay, H. et al. Sphingosine 1-phosphate receptor-1 in cardiomyocytes is required for normal cardiac development. Dev Biol 418, 157-165, doi:10.1016/j.ydbio.2016.06.024 (2016).

19 Maceyka, M., Alvarez, S. E., Milstien, S. \& Spiegel, S. Filamin A links sphingosine kinase 1 and sphingosine-1-phosphate receptor 1 at lamellipodia to orchestrate cell migration. Molecular and cellular biology 28, 5687-5697, doi:10.1128/MCB.00465-08 (2008). 
20 Le Tourneau, T. et al. New insights into mitral valve dystrophy: a Filamin-A genotypephenotype and outcome study. European heart journal 39, 1269-1277 (2018).

21 Hulin, A. et al. Macrophage Transitions in Heart Valve Development and Myxomatous Valve Disease. Arterioscler Thromb Vasc Biol 38, 636-644, doi:10.1161/ATVBAHA.117.310667 (2018).

22 Deroyer, C. et al. New biomarkers for primary mitral regurgitation. Clinical proteomics 12, 25, doi:10.1186/s12014-015-9097-2 (2015).

23 Lee, E. et al. Autophagy is essential for cardiac morphogenesis during vertebrate development. Autophagy 10, 572-587, doi:10.4161/auto.27649 (2014).

24 Scoville, D. W., Kang, H. S. \& Jetten, A. M. GLIS1-3: emerging roles in reprogramming, stem and progenitor cell differentiation and maintenance. Stem cell investigation 4, 80, doi:10.21037/sci.2017.09.01 (2017).

25 Koefoed, K., Veland, I. R., Pedersen, L. B., Larsen, L. A. \& Christensen, S. T. Cilia and coordination of signaling networks during heart development. Organogenesis 10, 108-125 (2014).

26 Katoh, Y. \& Katoh, M. Hedgehog signaling, epithelial-to-mesenchymal transition and miRNA. International journal of molecular medicine 22, 271-275 (2008).

27 Tan, T. Y. et al. Monoallelic BMP2 Variants Predicted to Result in Haploinsufficiency Cause Craniofacial, Skeletal, and Cardiac Features Overlapping Those of 20p12 Deletions. Am J Hum Genet 101, 985-994, doi:10.1016/j.ajhg.2017.10.006 (2017).

28 Liu, W. et al. Bmp4 signaling is required for outflow-tract septation and branchial-arch artery remodeling. Proc Natl Acad Sci $U$ S A 101, 4489-4494, doi:10.1073/pnas.0308466101 (2004).

29 Ellinor, P. T. et al. Meta-analysis identifies six new susceptibility loci for atrial fibrillation. Nat Genet 44, 670-675, doi:10.1038/ng.2261 (2012).

30 Kleinjan, D. A. \& van Heyningen, V. Long-range control of gene expression: emerging mechanisms and disruption in disease. Am J Hum Genet 76, 8-32, doi:10.1086/426833 (2005).

31 Marchini, J., Howie, B., Myers, S., McVean, G. \& Donnelly, P. A new multipoint method for genome-wide association studies by imputation of genotypes. Nat Genet 39, 906-913 (2007).

32 Purcell, S. et al. PLINK: a tool set for whole-genome association and population-based linkage analyses. Am J Hum Genet 81, 559-575 (2007).

33 Pruim, R. J. et al. LocusZoom: regional visualization of genome-wide association scan results. Bioinformatics 26, 2336-2337 (2010).

34 Zhang, K., Cui, S., Chang, S., Zhang, L. \& Wang, J. i-GSEA4GWAS: a web server for identification of pathways/gene sets associated with traits by applying an improved gene set enrichment analysis to genome-wide association study. Nucleic Acids Res 38, W90W95 (2010).

35 Zhang, K., Chang, S., Guo, L. \& Wang, J. I-GSEA4GWAS v2: a web server for functional analysis of SNPs in trait-associated pathways identified from genome-wide association study. Protein cell 6, 221 (2015).

36 Pers, T. H. et al. Biological interpretation of genome-wide association studies using predicted gene functions. Nat Commun 6, 5890 (2015). 
$42537 \quad$ Frey, B. J. \& Dueck, D. Clustering by passing messages between data points. science 315, $426 \quad 972-976(2007)$.

42738 Consortium, E. N. C. O. D. E. P. A user's guide to the encyclopedia of DNA elements

428 (ENCODE). PLoS biology 9, e1001046 (2011).

42939 Freese, N. H., Norris, D. C. \& Loraine, A. E. Integrated genome browser: visual analytics platform for genomics. Bioinformatics 32, 2089-2095, doi:10.1093/bioinformatics/btw069 (2016).

$43240 \quad$ Hawkins, R. D. et al. Distinct epigenomic landscapes of pluripotent and lineage-committed

433

434 human cells. Cell Stem Cell 6, 479-491, doi:10.1016/j.stem.2010.03.018 (2010).

435

41 Thurman, R. E. et al. The accessible chromatin landscape of the human genome. Nature 489, 75-82, doi:10.1038/nature11232 (2012).

436 


\section{Acknowledgments}

438 This study was supported by a PhD scholarship from the Chinese Scientific Council to MY, and

439 partly funded by French Agency of Research (ANR-16-CE17-0015-02). The work at MUSC was

440 performed in a facility constructed with support from the National Institutes of Health, Grant

441 Number C06 RR018823 from the Extramural Research Facilities Program of the National Center

442 for Research Resources. Other funding sources: National Heart Lung and Blood Institute:

443 HL131546 (RAN), COBRE GM103342 (RAN), GM103444 (RAN), HL127692 (DJM, SAS,

444 RAN, RAL), American Heart Association: 17CSA33590067 (RAN) and HL140187 (NRT). The

445 recruitment of the MVP France cohort was supported by the French Society of Cardiology. We

446 acknowledge the contribution of the Leducq Foundation, Paris for supporting a transatlantic

447 consortium investigating the physiopathology of mitral valve disease, for which this genome-

448 wide association study was a major project (coordinators: R.A.L. and A.A.H.). We acknowledge

449 investigatrs who contributed access to validation in cohorts: Leticia Fernandez-Friera, Jorge

450 Solis from Centro Nacional de Investigaciones Cardiovasculares (CNIC), Yohan Bossé and

451 Philippe Pibarot from Institut universitaire de cardiologie et de pneumologie de Québec-

452 Université Laval, Quebec, Canada, Ramachandran S. Vasan, Ming-Huei Chen and Emilia J.

453 Benjamin from the Framingham Heart Study, USA, Thierry Le Tourneau, Richard Redon, Hervé Le

454 Marec and Vincent Probst from Institut du Thorax, Nantes, France and Ronen Durst, Hassadah

455 Hebrew University Medical Center, Jerusalem, IL.

\section{Author contributions}

457 Recruitment of patients: A.A.H, R.A.L, S.A.S, F.N.D, X.J.

458 Genotyping: X.J, J.-J.S, C.D, S.A.S. 
459 Data analysis: M.Y, A.G, S.K

460 Animal experiments: D.J.M., R.A.N., N.T., P.T.E., K.T.

461 Manuscript writing: N.B.-N., M.Y, R.A.N., N.T., R.A.L.

462 Manuscript approval: all authors.

463

464 Competing interests

$465 \quad$ None

466 Materials \& Correspondence

467

$468 \quad$ Figures 


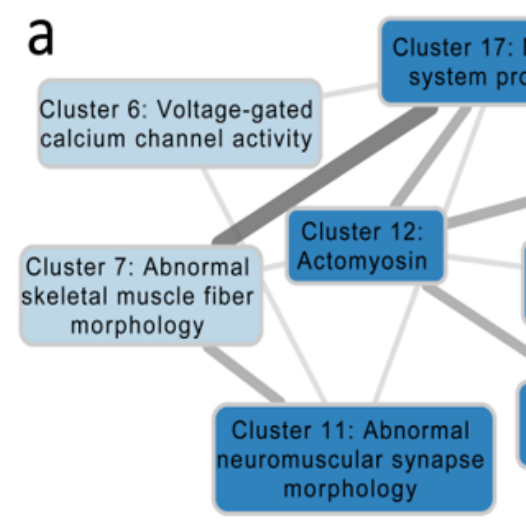

b
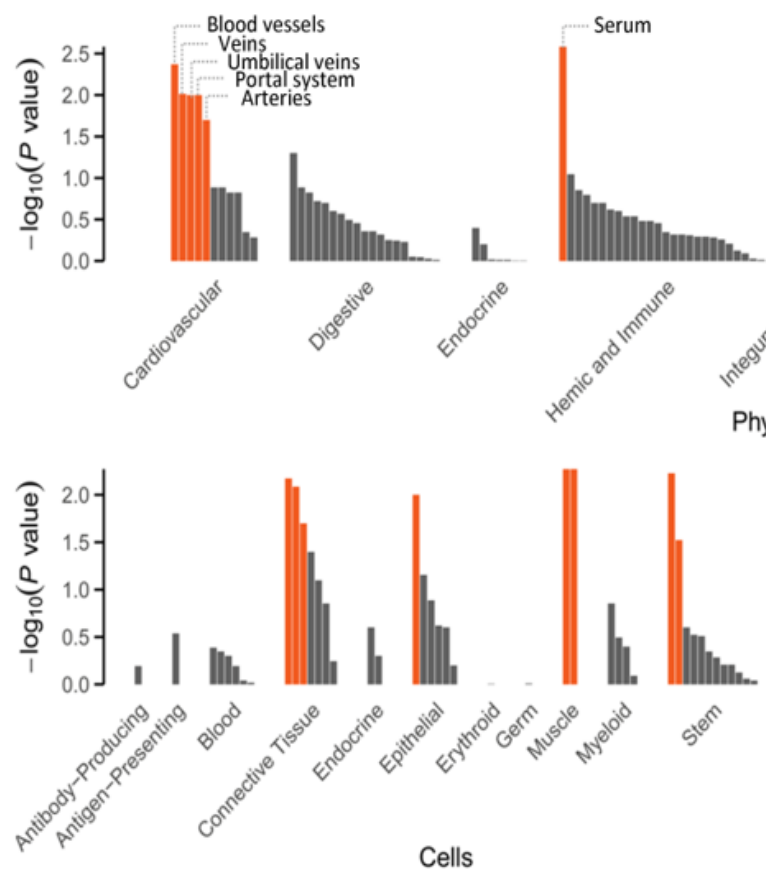
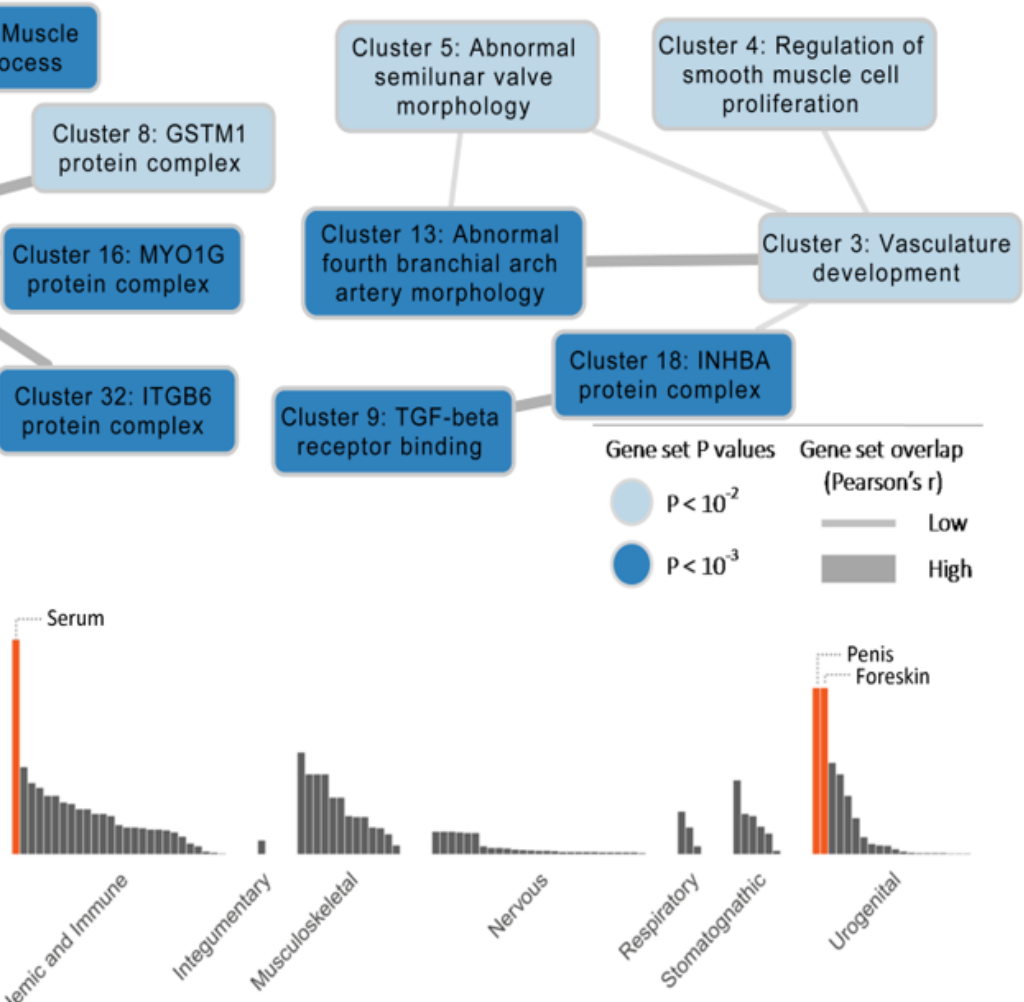

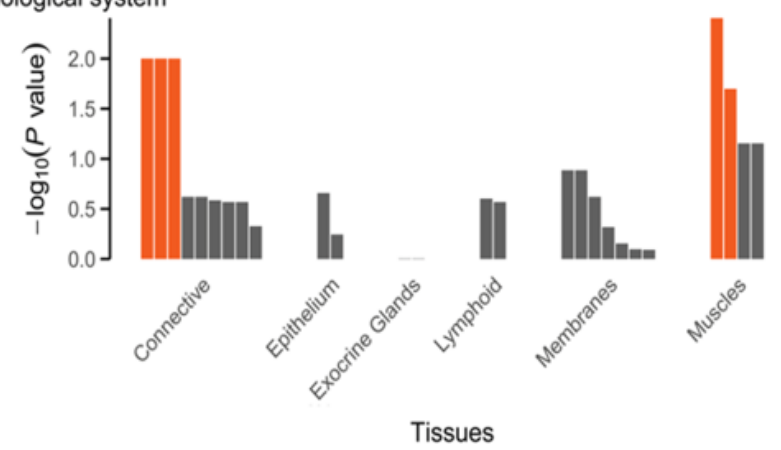

Figure 1. Networks of gene sets and tissue enrichment for the expression of genes at MVP associated loci. (a)

471 Clustering networks formed from MVP enriched gene sets. The significance of the enrichment of gene sets are

472 indicated (light blue: P-value $<10^{-2}$ and dark blue: P-value $<10^{-3}$ ). The thicker the edge, the more similar functions

473 exist between connected gene sets (all Pearson's $r>0.3$ ). (b) Tissue enriched for MVP genes. Enrichment is organised

474 by physiological system, cells and tissues. Tissues/cells type with FDR $<0.20$ are marked in orange. 


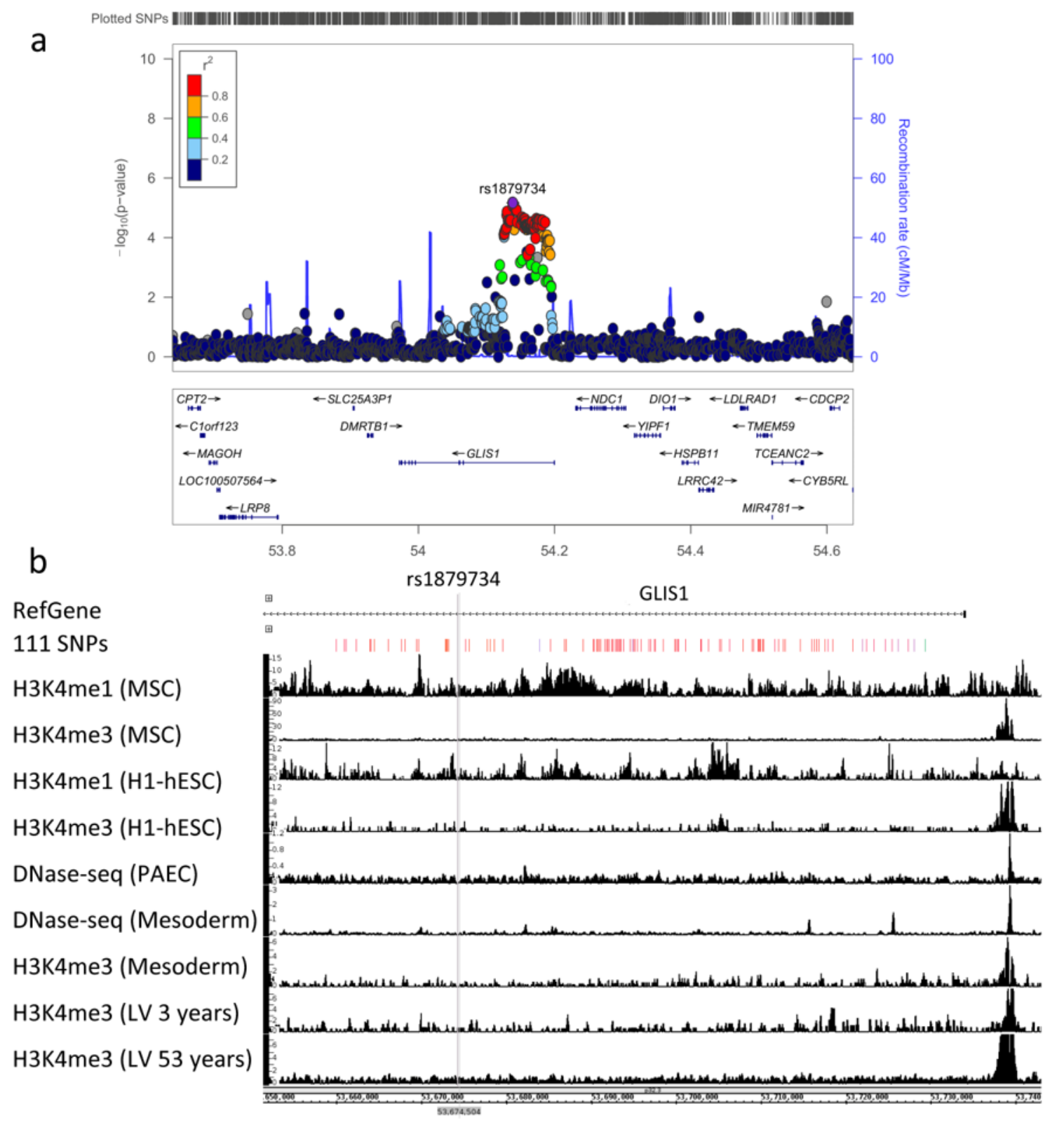

Figure 2. Genomic context and functional annotation of the association signal observed in the GWAS meta-

477 analysis. (a) The regional association plot was generated using LocusZoom and displays surrounding genes $( \pm 500$

$478 \mathrm{~Kb}$ ). The association signal is intronic to GLIS1. Round points represent SNPs in this region and purple point represent SNP rs1879734, the top associated SNP. (b) Visualization of histone marks and DNAse-seq density profiles in several tissues/cells based on ENCODE data. From top to bottom: reference gene; the selected 111 SNPs that is in high LD with rs1879734; H3K4me1 and H3K4me3 were from mesenchymal stem cell originated from H1-hESC; H3K4me1 and H3K4me3 from H1-hESC; DNase-seq from pulmonary artery endothelial cell; DNase-seq and H3K4me3 from cardiac mesoderm; H3K4me1 and $\mathrm{H} 3 \mathrm{~K} 4 \mathrm{me} 3$ from heart left ventricle. 
E13.5

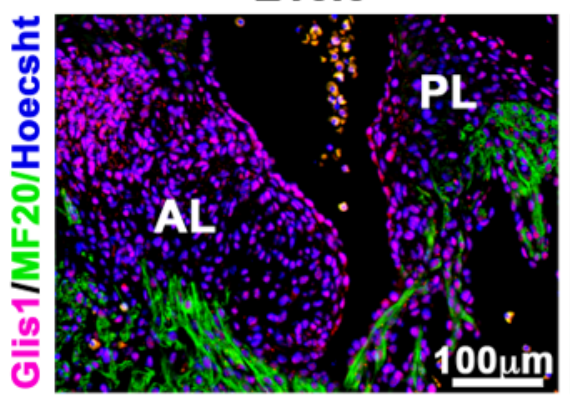

E17.5

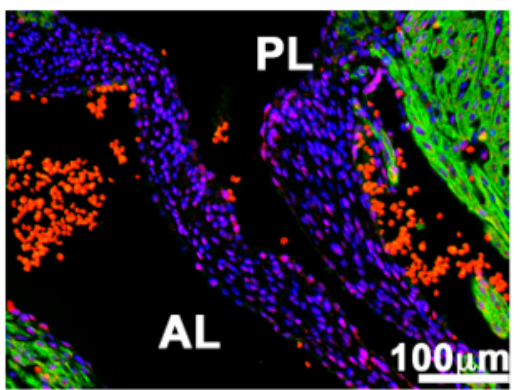

6-month

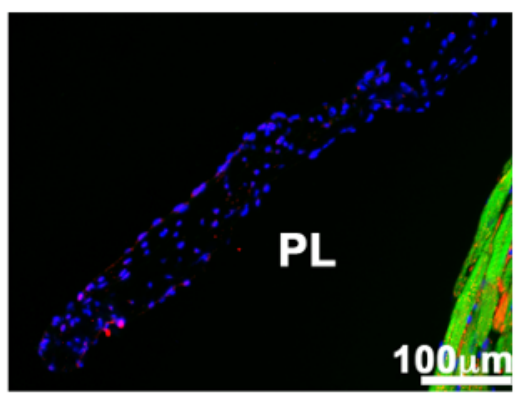

485 Figure 3. Glis1 expression in mouse developing and adult heart. Cardiac expression of Glis1 (red) was analysed at embryonic (E13.5), foetal (E17.5) and adult time points. Glis1 was detected during valve morphogenesis in mice (E.13 and E.17 stages), specifically during the completion of endothelial to mesenchymal transformation and valve sculpting and elongation and undetected in the adult valve (6 months). Glis1 is detected in nuclei from endothelial and valvular interstitial cells. Green tags are for MF20 marking sarcomeric myosin-myocytes, Blue is Hoescht coloration that indicates nuclei. 
a.

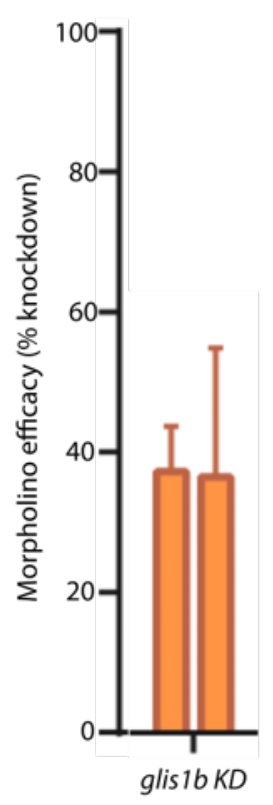

b.
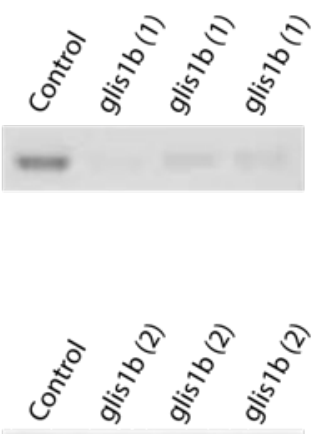

C.
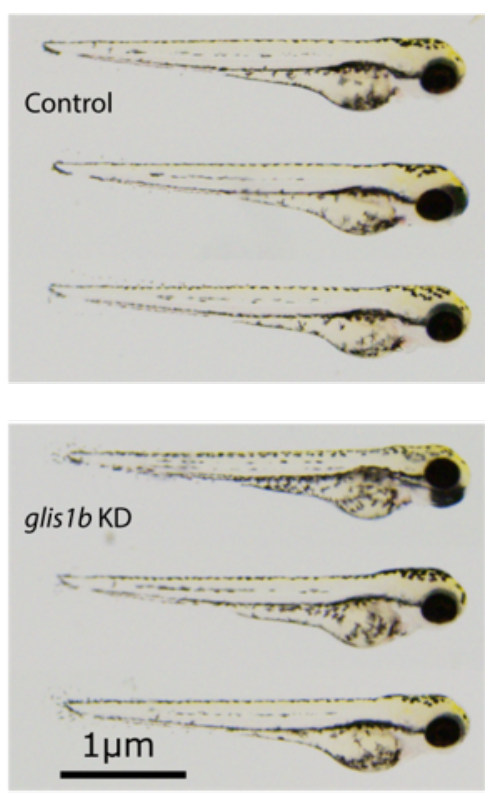

d.

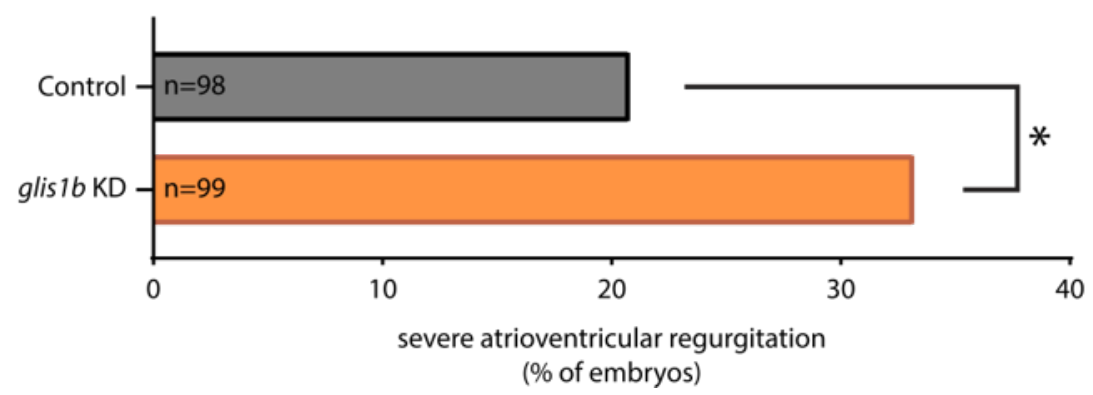

492 Figure 4. Assessment of cardiac regurgitation in zebrafish after morpholino knockdown of glis1b. (a)

493 Morpholino-mediated knockdown efficacy. Efficacy for glis1b in embryonic zebrafish was measured by RT-PCR. (b)

494 Representative gel images from analysis of morpholino efficacy. Control indicates samples amplified from control-

495 injected embryos. All samples were obtained from 72-hpf embryos. (c). Brightfield micrographs displaying gross

496 morphology of 72-hpf embryos following glis1 knockdown. Scale bar represents $1 \mu \mathrm{m}$. (d) Fold change in observed

497 atrioventricular regurgitation in 72-hpf zebrafish embryos after morpholino-mediated knockdown. All results are

498 relative to clutchmate controls. 
bioRxiv preprint doi: https://doi.org/10 1101/433268; this version posted October 2, 2018. The copyright holder for this preprint (which was not certified by peer review) is the author/funder, who has granted bioRxiv a license to display the preprint in perpetuity. It is made available under aCC-BY-NC-ND 4.0 International license.

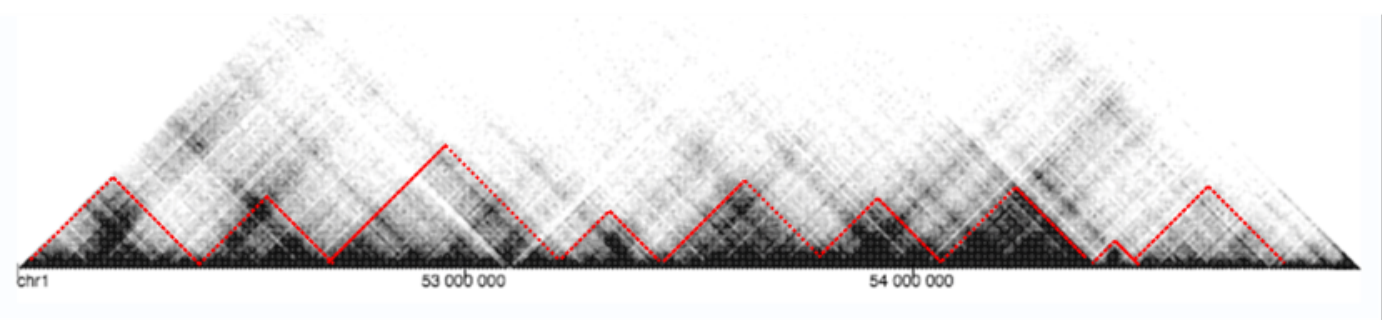

THP-1

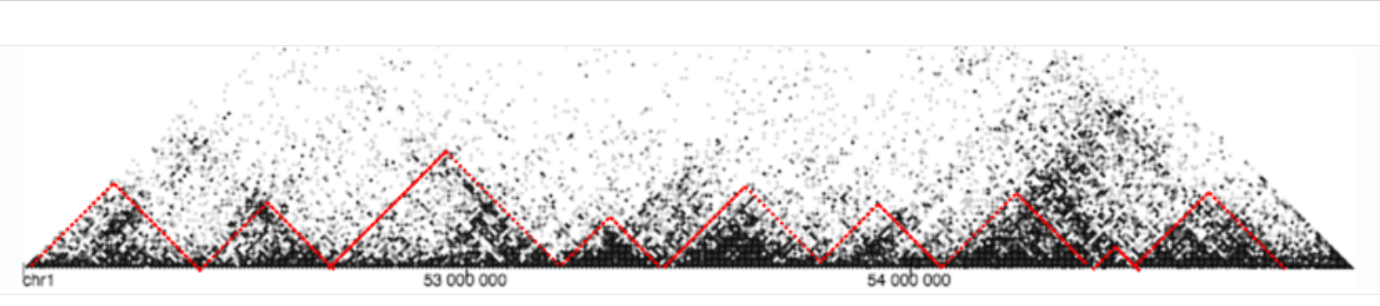

\section{HUVEC}

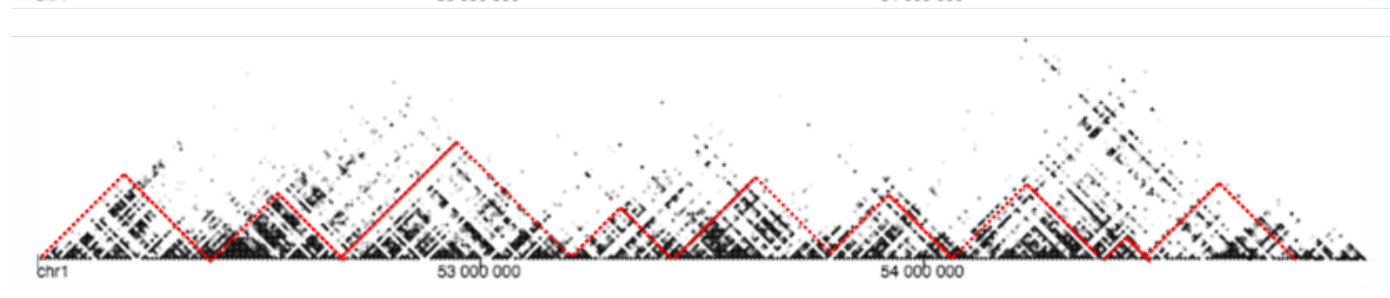

\section{H1-hESC}

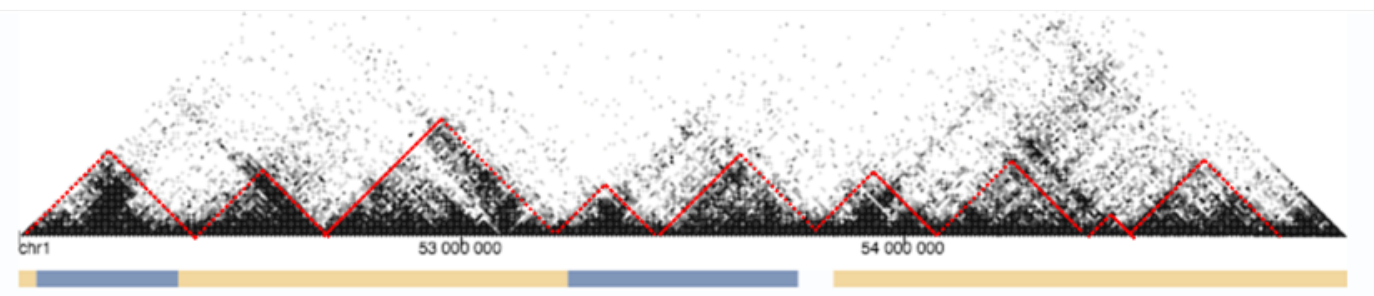

\section{NHEK}

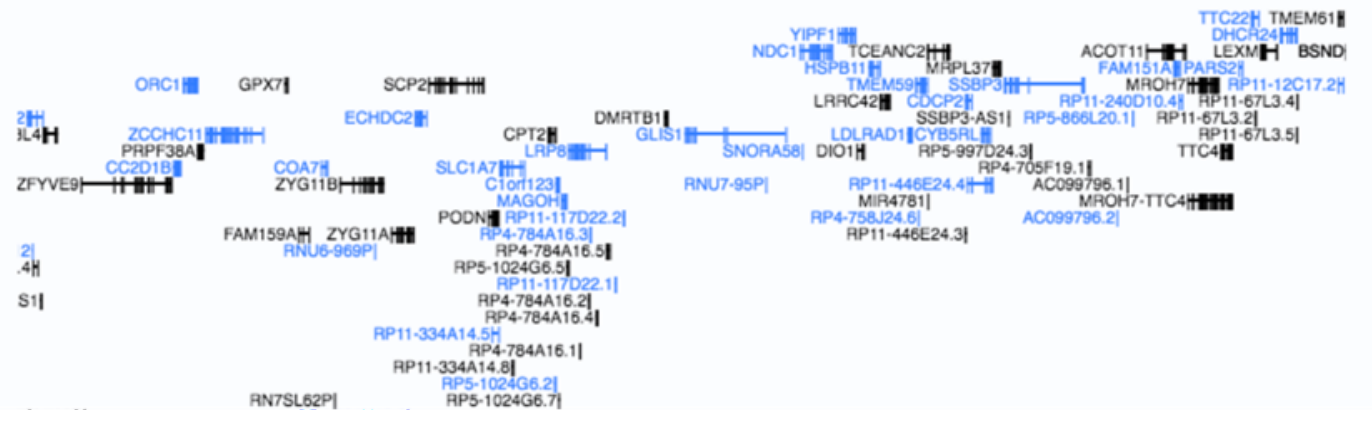

500 Supplementary Figure 1. Hi-C interaction of GLIS1 in several cell types. We selected Hi-C data from four cell

501 types includes THP-1, HUVEC, H1-hESC, NHEK from ENCODE, gene interaction visualized by Integrated Genome

502 Browser (IGB) was shown. By visualization of the topologically associating domains (TADs), the interaction in the

503 GLIS1 region was found to be mainly exists inside of GLIS1. 


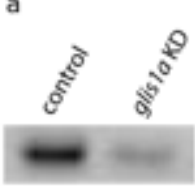

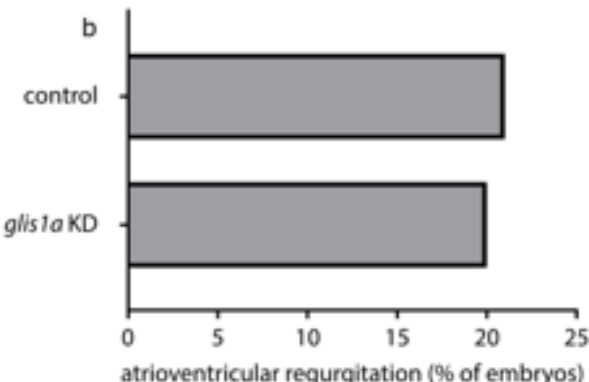

504

505 Supplementary Figure 2. Assessment of cardiac regurgitation in zebrafish after morpholino knockdown of

506 glis1a. (a) Representative gel images from analysis of morpholino efficacy. Control indicates samples amplified from

507 control-injected embryos. All samples were obtained from 72-hpf embryos. (b) Fold change in observed

508 atrioventricular regurgitation in 72-hpf zebrafish embryos after morpholino-mediated knockdown. 
bioRxiv preprint doi: https://doi.org/10.1101/433268; this version posted October 2, 2018. The copyright holder for this preprint (which was not

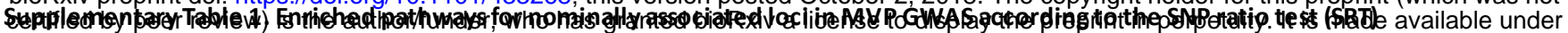

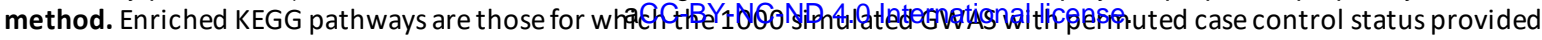
smaller counts of ratios of significant to non significant SNPs, when compared to GWAS with real phenotyes. We provide the count of ratios and empirical p-values (<0.05) for pathways. E.g Compared to the real GWAS, SNPs in genes in the phagosome pathway presented more significant associations with MVP only in 1 out of 1000 simulated GWAS. On the other hand, SNPs in genes from the Wnt signaling pathway presented more significant associations with MVP 50 simulated GWAS.

\begin{tabular}{|c|c|c|c|}
\hline Pathway ID in KEGG & Descriptive of the pathway & $\begin{array}{c}\text { Count of ratios of significant to non- } \\
\text { significant SNPs higher in simulated data }\end{array}$ & Empirical P value \\
\hline hsa04145 & Phagosome & 1 & 0.001 \\
\hline hsa05416 & Viral myocarditis & 1 & 0.001 \\
\hline hsa05410 & Hypertrophic cardiomyopathy (HCM) & 2 & 0.002 \\
\hline hsa05414 & Dilated cardiomyopathy & 2 & 0.002 \\
\hline hsa00190 & Oxidative phosphorylation & 3 & 0.003 \\
\hline hsa05340 & Primary immunodeficiency & 3 & 0.003 \\
\hline hsa00010 & Glycolysis / Gluconeogenesis & 4 & 0.004 \\
\hline hsa04612 & Antigen processing and presentation & 4 & 0.004 \\
\hline hsa00051 & Fructose and mannose metabolism & 5 & 0.005 \\
\hline hsa04260 & Cardiac muscle contraction & 5 & 0.005 \\
\hline hsa04672 & Intestinal immune network for IgA production & 5 & 0.005 \\
\hline hsa05140 & Leishmaniasis & 5 & 0.005 \\
\hline hsa05310 & Asthma & 5 & 0.005 \\
\hline hsa05330 & Allograft rejection & 5 & 0.005 \\
\hline hsa05332 & Graft-versus-host disease & 5 & 0.005 \\
\hline hsa01100 & Metabolic pathways & 6 & 0.006 \\
\hline hsa04070 & Phosphatidylinositol signaling system & 6 & 0.006 \\
\hline hsa00562 & Inositol phosphate metabolism & 7 & 0.007 \\
\hline hsa05320 & Autoimmune thyroid disease & 7 & 0.007 \\
\hline hsa04662 & B cell receptor signaling pathway & 8 & 0.008 \\
\hline hsa04940 & Type I diabetes mellitus & 8 & 0.008 \\
\hline hsa05210 & Colorectal cancer & 10 & 0.010 \\
\hline hsa05144 & Malaria & 11 & 0.011 \\
\hline hsa05322 & Systemic lupus erythematosus & 11 & 0.011 \\
\hline hsa04660 & T cell receptor signaling pathway & 12 & 0.012 \\
\hline hsa00740 & Riboflavin metabolism & 15 & 0.015 \\
\hline hsa00750 & Vitamin B6 metabolism & 15 & 0.015 \\
\hline hsa04370 & VEGF signaling pathway & 16 & 0.016 \\
\hline hsa04930 & Type II diabetes mellitus & 18 & 0.018 \\
\hline hsa04962 & Vasopressin-regulated water reabsorption & 18 & 0.018 \\
\hline hsa00524 & Butirosin and neomycin biosynthesis & 25 & 0.025 \\
\hline hsa04010 & MAPK signaling pathway & 30 & 0.030 \\
\hline hsa00920 & Sulfur metabolism & 31 & 0.031 \\
\hline hsa00603 & Glycosphingolipid biosynthesis - globo series & 36 & 0.036 \\
\hline hsa04270 & Vascular smooth muscle contraction & 36 & 0.036 \\
\hline hsa00350 & Tyrosine metabolism & 37 & 0.037 \\
\hline hsa04540 & Gap junction & 41 & 0.041 \\
\hline hsa04650 & Natural killer cell mediated cytotoxicity & 45 & 0.045 \\
\hline hsa05215 & Prostate cancer & 45 & 0.045 \\
\hline hsa00970 & Aminoacyl-tRNA biosynthesis & 48 & 0.048 \\
\hline hsa04966 & Collecting duct acid secretion & 48 & 0.048 \\
\hline hsa04310 & Wnt signaling pathway & 50 & 0.050 \\
\hline
\end{tabular}




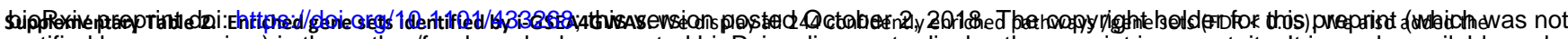

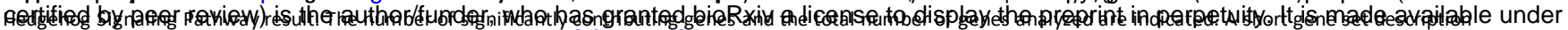

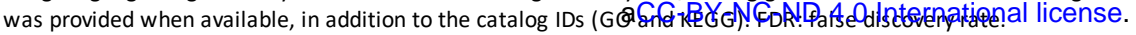

\begin{tabular}{|c|c|c|c|c|c|}
\hline Gene Set Name & $\begin{array}{l}\text { Significant } \\
\text { genes }\end{array}$ & $\begin{array}{c}\text { Total genes } \\
\text { analyzed }\end{array}$ & P Value & FDR & Gene Set Description \\
\hline Biocarta: EDG1 Pathway & 26 & 27 & 0.001 & $1.00 \mathrm{E}-03$ & Phospholipids as signalling intermediaries \\
\hline GO: Actin Binding & 58 & 76 & 0.001 & $1.00 \mathrm{E}-03$ & $\begin{array}{l}\text { GO:0003779. Interacting selectively with monomeric or multimeric forms of actin, including } \\
\text { actin filaments. }\end{array}$ \\
\hline GO: Adherens Junction & 18 & 23 & 0.001 & $1.00 \mathrm{E}-03$ & $\begin{array}{l}\text { GO:0005912. A cell junction at which the cytoplasmic face of the plasma membrane is } \\
\text { attached to actin filaments. }\end{array}$ \\
\hline GO: Anion Transport & 24 & 31 & 0.001 & $1.00 \mathrm{E}-03$ & $\begin{array}{l}\text { GO:0006820. The directed movement of anions, atoms or small molecules with a net } \\
\text { negative charge, into, out of, within or between cells. }\end{array}$ \\
\hline GO: Basolateral Plasma Membrane & 28 & 35 & 0.001 & $1.00 E-03$ & $\begin{array}{l}\text { GO:0016323. Part of the plasma membrane that includes the basal end and sides of the cell. } \\
\text { Often used in reference to animal polarized epithelial membranes, where the basal } \\
\text { membrane is the part attached to the extracellular matrix, or in plant cells, where the basal } \\
\text { membrane is defined with respect to the zygotic axis. }\end{array}$ \\
\hline GO: Transcription Repressor Activity & 94 & 148 & 0.001 & $1.00 \mathrm{E}-03$ & $\begin{array}{l}\text { GO:0016564. Any transcription regulator activity that prevents or downregulates } \\
\text { transcription. }\end{array}$ \\
\hline GO: Vasculature Development & 41 & 55 & 0.001 & $1.00 \mathrm{E}-03$ & $\begin{array}{l}\text { GO:0001944. The process whose specific outcome is the progression of the vasculature over } \\
\text { time, from its formation to the mature structure. }\end{array}$ \\
\hline GO: Cytoskeletal Protein Binding & 112 & 159 & 0.001 & $1.10 \mathrm{E}-03$ & $\begin{array}{l}\text { GO:0008092. Interacting selectively with any protein component of any cytoskeleton (actin, } \\
\text { microtubule, or intermediate filament cytoskeleton). }\end{array}$ \\
\hline KEGG: Intestinal Immune Network for IGA Production & 31 & 45 & 0.001 & $1.11 \mathrm{E}-03$ & hsa04672 \\
\hline GO: Ion Transport & 131 & 180 & 0.001 & $1.13 \mathrm{E}-03$ & $\begin{array}{l}\text { GO:0006811. The directed movement of charged atoms or small charged molecules into, } \\
\text { out of, within or between cells. }\end{array}$ \\
\hline Biocarta: Integrin Pathway & 30 & 38 & 0.001 & $1.18 \mathrm{E}-03$ & Integrin Signaling Pathway \\
\hline KEGG: Dilated Cardiomyopathy & 68 & 90 & 0.001 & $1.31 \mathrm{E}-03$ & hsa05414 \\
\hline GO: Structural Constituent of Cytoskeleton & 39 & 57 & 0.001 & $1.33 \mathrm{E}-03$ & $\begin{array}{l}\text { GO:0005200. The action of a molecule that contributes to the structural integrity of a } \\
\text { cytoskeletal structure. }\end{array}$ \\
\hline GO: Actin Filament Binding & 21 & 25 & 0.001 & $1.35 \mathrm{E}-03$ & $\begin{array}{l}\text { GO:0051015. Interacting selectively with an actin filament, also known as F-actin, a helical } \\
\text { filamentous polymer of globular G-actin subunits. }\end{array}$ \\
\hline GO: Sulfur Metabolic Process & 31 & 37 & 0.001 & $1.36 \mathrm{E}-03$ & $\begin{array}{l}\text { GO:0006790. The chemical reactions and pathways involving the nonmetallic element sulfur } \\
\text { or compounds that contain sulfur, such as the amino acids methionine and cysteine or the } \\
\text { tripeptide glutathione. }\end{array}$ \\
\hline GO: Angiogenesis & 36 & 48 & 0.001 & $1.37 \mathrm{E}-03$ & $\begin{array}{l}\text { GO: } 0001525 \text {. Blood vessel formation when new vessels emerge from the proliferation of pre } \\
\text { existing blood vessels. }\end{array}$ \\
\hline GO: Cell Cortex & 30 & 39 & 0.001 & $1.38 \mathrm{E}-03$ & $\begin{array}{l}\text { GO:0005938. The region of a cell that lies just beneath the plasma membrane and often, but } \\
\text { not always, contains a network of actin filaments and associated proteins. }\end{array}$ \\
\hline KEGG: Cell Adhesion Molecules Cams & 91 & 127 & 0.001 & $1.38 \mathrm{E}-03$ & hsa04514 \\
\hline GO: Positive Regulation of Cell Proliferation & 97 & 145 & 0.001 & $1.39 \mathrm{E}-03$ & GO:0008284. Any process that activates or increases the rate or extent of cell proliferation. \\
\hline GO: Anion Transmembrane Transporter Activity & 43 & 59 & 0.001 & $1.39 \mathrm{E}-03$ & $\begin{array}{l}\text { GO:0008509. Catalysis of the transfer of a negatively charged ion from one side of a } \\
\text { membrane to the other. }\end{array}$ \\
\hline GO: Anatomical Structure formation & 42 & 56 & 0.001 & $1.40 \mathrm{E}-03$ & $\begin{array}{l}\text { G0:0048646. The process pertaining to the initial formation of an anatomical structure from } \\
\text { unspecified parts. This process begins with the specific processes that contribute to the } \\
\text { appearance of the discrete structure and ends when the structural rudiment is recognizable. } \\
\text { An anatomical structure is any biological entity that occupies space and is distinguished from } \\
\text { its surroundings. Anatomical structures can be macroscopic such as a carpel, or microscopic } \\
\text { such as an acrosome. }\end{array}$ \\
\hline Biocarta: SPPA Pathway & 20 & 22 & 0.001 & $1.40 \mathrm{E}-03$ & Aspirin Blocks Signaling Pathway Involved in Platelet Activation \\
\hline KEGG: Focal Adhesion & 145 & 198 & 0.001 & $1.41 \mathrm{E}-03$ & hsa04510 \\
\hline GO: Transcription Corepressor Activity & 58 & 90 & 0.001 & $1.42 \mathrm{E}-03$ & $\begin{array}{l}\text { GO:0003714. The function of a transcription cofactor that represses transcription from a RNA } \\
\text { polymerase II promoter; does not bind DNA itself. }\end{array}$ \\
\hline $\begin{array}{l}\text { GO: DI TRI Valent Inorganic Cation Transmembrane } \\
\text { Transporter Activity }\end{array}$ & 18 & 22 & 0.001 & $1.43 \mathrm{E}-03$ & $\begin{array}{l}\text { GO:0015082. Catalysis of the transfer of inorganic cations with a valency of two or three } \\
\text { from one side of the membrane to the other. Inorganic cations are atoms or small molecules } \\
\text { with a positive charge that do not contain carbon in covalent linkage. }\end{array}$ \\
\hline $\begin{array}{l}\text { GO: Positive Regulation of Transcription DNA } \\
\text { Dependent }\end{array}$ & 82 & 118 & 0.001 & $1.44 \mathrm{E}-03$ & $\begin{array}{l}\text { GO:0045893. Any process that activates or increases the frequency, rate or extent of DNA- } \\
\text { dependent transcription. }\end{array}$ \\
\hline GO: Substrate Specific Channel Activity & 108 & 154 & 0.001 & $1.45 \mathrm{E}-03$ & $\begin{array}{l}\text { GO:0022838. Catalysis of energy-independent facilitated diffusion, mediated by passage of } \\
\text { a specific solute through a transmembrane aqueous pore or channel. Stereospecificity is not } \\
\text { exhibited but this transport may be specific for a particular molecular species or class of } \\
\text { molecules. }\end{array}$ \\
\hline GO: Ion Channel Activity & 104 & 147 & 0.001 & $1.46 \mathrm{E}-03$ & $\begin{array}{l}\text { GO:0005216. Catalysis of facilitated diffusion of an ion (by an energy-independent process) } \\
\text { by passage through a transmembrane aqueous pore or channel without evidence for a } \\
\text { carrier-mediated mechanism. }\end{array}$ \\
\hline KEGG: Pentose Phosphate Pathway & 20 & 25 & 0.001 & $1.55 \mathrm{E}-03$ & hsa00030 \\
\hline GO: Cell Cortex Part & 19 & 24 & 0.001 & $1.55 \mathrm{E}-03$ & $\begin{array}{l}\text { GO:0044448. Any constituent part of the cell cortex, the region of a cell that lies just beneath } \\
\text { the plasma membrane and often, but not always, contains a network of actin filaments and } \\
\text { associated proteins. }\end{array}$ \\
\hline GO: Transcription Activator Activity & 112 & 170 & 0.001 & $1.56 \mathrm{E}-03$ & $\begin{array}{l}\text { GO:0016563. Any transcription regulator activity required for initiation or upregulation of } \\
\text { transcription. }\end{array}$ \\
\hline GO: Transmembrane Receptor Protein Kinase Activity & 41 & 51 & 0.001 & $1.57 \mathrm{E}-03$ & GO:0019199. \\
\hline GO: Positive Regulation of RNA Metabolic Process & 83 & 120 & 0.001 & $1.57 \mathrm{E}-03$ & $\begin{array}{l}\text { GO:0051254. Any process that activates or increases the frequency, rate or extent of the } \\
\text { chemical reactions and pathways involving RNA. }\end{array}$ \\
\hline GO: Metal Ion Transmembrane Transporter Activity & 105 & 145 & 0.001 & $1.59 \mathrm{E}-03$ & $\begin{array}{l}\text { GO:0046873. Catalysis of the transfer of metal ions from one side of a membrane to the } \\
\text { other. }\end{array}$ \\
\hline GO: mRNA Metabolic Process & 43 & 82 & 0.001 & $1.59 \mathrm{E}-03$ & $\begin{array}{l}\text { GO:0016071. The chemical reactions and pathways involving mRNA, messenger RNA, which } \\
\text { is responsible for carrying the coded genetic 'message', transcribed from DNA, to sites of } \\
\text { protein assembly at the ribosomes. }\end{array}$ \\
\hline GO: Cytoskeleton Dependent Intracellular Transport & 20 & 26 & 0.001 & $1.62 \mathrm{E}-03$ & $\begin{array}{l}\text { GO:0030705. The directed movement of substances along cytoskeletal elements such as } \\
\text { microfilaments or microtubules within a cell. }\end{array}$ \\
\hline GO: Sulfotransferase Activity & 23 & 28 & 0.001 & $1.64 \mathrm{E}-03$ & $\begin{array}{l}\text { GO:0008146. Catalysis of the transfer of a sulfate group from 3'-phosphoadenosine 5'- } \\
\text { phosphosulfate to the hydroxyl group of an acceptor, producing the sulfated derivative and } \\
\text { 3'-phosphoadenosine 5'-phosphate. }\end{array}$ \\
\hline GO: mRNA Processing GO 0006397 & 37 & 72 & 0.001 & $1.68 \mathrm{E}-03$ & $\begin{array}{l}\text { GO:0006397. Any process involved in the conversion of a primary mRNA transcript into one } \\
\text { or more mature mRNA(s) prior to translation into polypeptide. }\end{array}$ \\
\hline $\begin{array}{l}\text { GO: Enzyme Linked Receptor Protein Signaling } \\
\text { Pathway }\end{array}$ & 108 & 140 & 0.001 & $1.74 \mathrm{E}-03$ & $\begin{array}{l}\text { GO:0007167. Any series of molecular signals initiated by the binding of an extracellular } \\
\text { ligand to a receptor on the surface of the target cell, where the receptor possesses catalytic } \\
\text { activity or is closely associated with an enzyme such as a protein kinase. }\end{array}$ \\
\hline
\end{tabular}




\begin{tabular}{|c|c|c|c|c|c|}
\hline \multicolumn{6}{|c|}{ 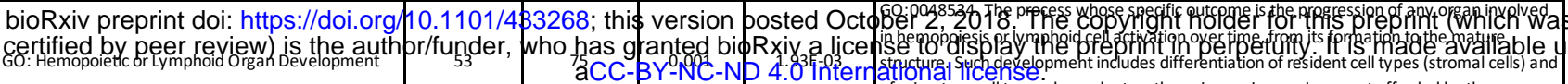 } \\
\hline GO: Lyase Activity & 46 & 68 & 0.001 & $1.95 \mathrm{E}-03$ & $\begin{array}{l}\text { GO:0016829. Catalysis of the cleavage of C-C, C-O, C-N and other bonds by other means } \\
\text { than by hydrolysis or oxidation, or conversely adding a group to a double bond. They differ } \\
\text { from other enzymes in that two substrates are involved in one reaction direction, but only } \\
\text { one in the other direction. When acting on the single substrate, a molecule is eliminated and } \\
\text { this generates either a new double bond or a new ring. }\end{array}$ \\
\hline KEGG: Hypertrophic Cardiomyopathy HCM & 60 & 83 & 0.001 & $1.98 \mathrm{E}-03$ & hsa05410 \\
\hline $\begin{array}{l}\text { GO: Transmembrane Receptor Protein Tyrosine } \\
\text { Kinase Activity }\end{array}$ & 36 & 43 & 0.001 & $1.98 \mathrm{E}-03$ & $\begin{array}{l}\text { GO:0004714. Catalysis of the reaction: ATP + a protein-L-tyrosine = ADP + a protein-L- } \\
\text { tyrosine phosphate, to initiate a change in cell activity. }\end{array}$ \\
\hline GO: Striated Muscle Development & 26 & 40 & 0.001 & $2.00 \mathrm{E}-03$ & $\begin{array}{l}\text { G0:0014706. The process whose specific outcome is the progression of a striated muscle } \\
\text { over time, from its formation to the mature structure. Striated muscle contain fibers that are } \\
\text { divided by transverse bands into striations, and cardiac and skeletal muscle are types of } \\
\text { striated muscle. Skeletal muscle myoblasts fuse to form myotubes and eventually } \\
\text { multinucleated muscle fibers. The fusion of cardiac cells is very rare and can only form } \\
\text { binucleate cells. }\end{array}$ \\
\hline GO: Cation Transport & 102 & 143 & 0.001 & $2.00 \mathrm{E}-03$ & $\begin{array}{l}\text { GO:0006812. The directed movement of cations, atoms or small molecules with a net } \\
\text { positive charge, into, out of, within or between cells. }\end{array}$ \\
\hline $\begin{array}{l}\begin{array}{l}\text { GO: Regulation of G Protein Coupled Receptor Protein } \\
\text { Signaling Pathway }\end{array} \\
\end{array}$ & 19 & 22 & 0.001 & $2.02 \mathrm{E}-03$ & $\begin{array}{l}\text { GO:0008277. Any process that modulates the frequency, rate or extent of G-protein coupled } \\
\text { receptor protein signaling pathway activity. }\end{array}$ \\
\hline KEGG: Oxidative Phosphorylation & 62 & 113 & 0.001 & $2.15 \mathrm{E}-03$ & hsa00190 \\
\hline GO: Regulation of Neurotransmitter Levels & 17 & 24 & 0.001 & $2.19 \mathrm{E}-03$ & GO:0001505. Any process that modulates levels of neurotransmitter. \\
\hline GO: Endosome Transport & 17 & 23 & 0.001 & $2.61 \mathrm{E}-03$ & $\begin{array}{l}\text { GO:0016197. The directed movement of substances into, out of or mediated by an } \\
\text { endosome, a membrane-bound organelle that carries materials newly ingested by } \\
\text { endocytosis. It passes many of the materials to lysosomes for degradation. }\end{array}$ \\
\hline GO: Organ Morphogenesis & 99 & 144 & 0.001 & $2.64 \mathrm{E}-03$ & $\begin{array}{l}\text { GO:0009887. Morphogenesis of an organ. An organ is defined as a tissue or set of tissues } \\
\text { that work together to perform a specific function or functions. Morphogenesis is the process } \\
\text { by which anatomical structures are generated and organized. Organs are commonly } \\
\text { observed as visibly distinct structures, but may also exist as loosely associated clusters of } \\
\text { cells that work together to perform a specific function or functions. }\end{array}$ \\
\hline GO: Regulation of Angiogenesis & 20 & 26 & 0.001 & $2.75 \mathrm{E}-03$ & GO:0045765. Any process that modulates the frequency, rate or extent of angiogenesis. \\
\hline GO: Deoxyribonuclease Activity & 14 & 22 & 0.001 & $2.76 \mathrm{E}-03$ & GO:0004536. Catalysis of the hy drolysis of ester linkages within deoxyribonucleic acid. \\
\hline GO: Immune System Development & 55 & 79 & 0.001 & $2.77 \mathrm{E}-03$ & $\begin{array}{l}\text { GO:0002520. The process whose specific outcome is the progression of an organismal } \\
\text { system whose objective is to provide calibrated responses by an organism to a potential } \\
\text { internal or invasive threat, over time, from its formation to the mature structure. A system is } \\
\text { a regularly interacting or interdependent group of organs or tissues that work together to } \\
\text { carrv out a given biological process. }\end{array}$ \\
\hline GO: DNA Catabolic Process & 18 & 23 & 0.001 & $2.78 \mathrm{E}-03$ & $\begin{array}{l}\text { GO:0006308. The chemical reactions and pathways resulting in the breakdown of DNA, } \\
\text { deoxyribonucleic acid, one of the two main types of nucleic acid, consisting of a long } \\
\text { unbranched macromolecule formed from one or two strands of linked deoxyribonucleotides, } \\
\text { the 3'-phosphate group of each constituent deoxyribonucleotide being joined in } 3 \text { ',5'- } \\
\text { phosphodiester linkage to the 5'-hydroxyl group of the deoxyribose moiety of the next one. }\end{array}$ \\
\hline GO: Hemopoiesis & 51 & 73 & 0.001 & $2.80 \mathrm{E}-03$ & $\begin{array}{l}\text { GO:0030097. The process whose specific outcome is the progression of the myeloid and } \\
\text { lymphoid derived organ/tissue systems of the blood and other parts of the body over time, } \\
\text { from formation to the mature structure. The site of hemopoiesis is variable during } \\
\text { development, but occurs primarily in bone marrow or kidney in many adult vertebrates. }\end{array}$ \\
\hline GO: Structural Constituent of Muscle & 22 & 33 & 0.002 & $2.84 \mathrm{E}-03$ & $\begin{array}{l}\text { GO:0008307. The action of a molecule that contributes to the structural integrity of a muscle } \\
\text { fiber. }\end{array}$ \\
\hline GO: Detection of Stimulus & 35 & 46 & 0.001 & $2.84 \mathrm{E}-03$ & $\begin{array}{l}\text { GO:0051606. The series of events in which a stimulus is received by a cell and converted } \\
\text { into a molecular signal. }\end{array}$ \\
\hline GO: Actin Cytoskeleton & 84 & 128 & 0.001 & $2.88 \mathrm{E}-03$ & $\begin{array}{l}\text { GO:0015629. The part of the cytoskeleton (the internal framework of a cell) composed of } \\
\text { actin and associated proteins. Includes actin cytoskeleton-associated complexes. }\end{array}$ \\
\hline KEGG: Tight Junction & 85 & 127 & 0.001 & $3.00 \mathrm{E}-03$ & hsa04530 \\
\hline Biocarta: MPR Pathway & 25 & 34 & 0.001 & $3.02 \mathrm{E}-03$ & How Progesterone Initiates Oocyte Membrane \\
\hline GO: Positive Regulation of Transcription & 97 & 143 & 0.001 & $3.24 \mathrm{E}-03$ & $\begin{array}{l}\text { GO:0045941. Any process that activates or increases the frequency, rate or extent of } \\
\text { transcription. }\end{array}$ \\
\hline GO: Di-, Tri-valent Inorganic Cation Transport & 26 & 32 & 0.001 & $3.25 \mathrm{E}-03$ & $\begin{array}{l}\text { GO:0015674. The directed movement of inorganic cations with a valency of two or three } \\
\text { into, out of, within or between cells. Inorganic cations are atoms or small molecules with a } \\
\text { positive charge which do not contain carbon in covalent linkage. }\end{array}$ \\
\hline KEGG: Cardiac Muscle Contraction & 48 & 72 & 0.001 & $3.33 \mathrm{E}-03$ & hsa04260 \\
\hline GO: RNA Processing & 88 & 166 & 0.001 & $3.45 \mathrm{E}-03$ & $\begin{array}{l}\text { GO:0006396. Any process involved in the conversion of one or more primary RNA transcripts } \\
\text { into one or more mature RNA molecules. }\end{array}$ \\
\hline GO: Sensory Perception & 123 & 185 & 0.001 & $3.80 \mathrm{E}-03$ & $\begin{array}{l}\text { GO:0007600. The series of events required for an organism to receive a sensory stimulus, } \\
\text { convert it to a molecular signal, and recognize and characterize the signal. }\end{array}$ \\
\hline Biocarta: METPathway & 29 & 37 & 0.001 & $3.81 \mathrm{E}-03$ & Signaling of Hepatocyte Growth Factor Receptor \\
\hline GO: Phosphoric Ester Hydrolase Activity & 103 & 149 & 0.001 & $3.85 \mathrm{E}-03$ & $\begin{array}{l}\mathrm{GO}: 0042578 \text {. Catalysis of the reaction: } \mathrm{RPO}-\mathrm{R}^{\prime}+\mathrm{H} 2 \mathrm{O}=\mathrm{RPOOH}+\mathrm{R}^{\prime} \mathrm{H} \text {. This reaction is the } \\
\text { hydrolysis of any phosphoric ester bond, any ester formed from orthophosphoric acid, } \\
\mathrm{O}=\mathrm{P}(\mathrm{OH}) 3 \text {. }\end{array}$ \\
\hline GO: Collagen & 21 & 23 & 0.001 & $3.85 \mathrm{E}-03$ & $\begin{array}{l}\text { GO:0005581. Any of the various assemblies in which collagen chains form a left-handed } \\
\text { triple helix; may assemble into higher order structures. }\end{array}$ \\
\hline GO: Calcium Ion Transport & 22 & 27 & 0.001 & $3.88 \mathrm{E}-03$ & $\begin{array}{l}\text { GO:0006816. The directed movement of calcium (Ca) ions into, out of, within or between } \\
\text { cells. }\end{array}$ \\
\hline Biocarta: PDINS Pathway & 17 & 23 & 0.002 & 3.89E-03 & Phosphoinositides and their downstream targets. \\
\hline $\begin{array}{l}\text { GO: Positive Regulation of } \\
\text { Nucleobasenucleosidenucleotide and Nucleic Acid } \\
\text { Metabolic Process }\end{array}$ & 103 & 153 & 0.001 & $4.08 \mathrm{E}-03$ & $\begin{array}{l}\text { GO:0045935. Any process that activates or increases the frequency, rate or extent of the } \\
\text { chemical reactions and pathways involving nucleobases, nucleosides, nucleotides and } \\
\text { nucleic acids. }\end{array}$ \\
\hline GO: Microtubule Based Process & 58 & 81 & 0.001 & 4.10E-03 & $\begin{array}{l}\text { GO:0007017. Any cellular process that depends upon or alters the microtubule cytoskeleton, } \\
\text { that part of the cytoskeleton comprising microtubules and their associated proteins. }\end{array}$ \\
\hline GO: Phosphoric Monoester Hydrolase Activity & 76 & 108 & 0.001 & 4.53E-03 & $\begin{array}{l}\text { GO:0016791. Catalysis of the hydrolysis of phosphoric monoesters, releasing inorganic } \\
\text { phosphate. }\end{array}$ \\
\hline GO: Actin Filament Based Process & 71 & 113 & 0.002 & 4.66E-03 & $\begin{array}{l}\text { GO:0030029. Any cellular process that depends upon or alters the actin cytoskeleton, that } \\
\text { part of the cytoskeleton comprising actin filaments and their associated proteins. }\end{array}$ \\
\hline GO: Regulation of Cell Differentiation & 44 & 60 & 0.001 & $4.68 \mathrm{E}-03$ & $\begin{array}{l}\text { GO:0045595. Any process that modulates the frequency, rate or extent of cell } \\
\text { differentiation, the process whereby relatively unspecialized cells acquire specialized } \\
\text { structural and functional features. }\end{array}$ \\
\hline GO: Regulation of Cytokine Production & 18 & 24 & 0.001 & 4.82E-03 & $\begin{array}{l}\text { GO:0001817. Any process that modulates the frequency, rate, or extent of production of a } \\
\text { cytokine. }\end{array}$ \\
\hline GO: Cell Migration & 69 & 94 & 0.001 & 4.83E-03 & $\begin{array}{l}\text { GO:0016477. The orderly movement of cells from one site to another, often during the } \\
\text { development of a multicellular organism. }\end{array}$ \\
\hline GO: Kinase Inhibitor Activity & 16 & 25 & 0.001 & 4.84E-03 & $\begin{array}{l}\text { GO:0019210. Stops, prevents or reduces the activity of a kinase, an enzyme which catalyzes } \\
\text { of the transfer of a phosphate group, usually from ATP, to a substrate molecule. }\end{array}$ \\
\hline
\end{tabular}




\begin{tabular}{|c|c|c|c|c|c|}
\hline \multicolumn{6}{|c|}{ 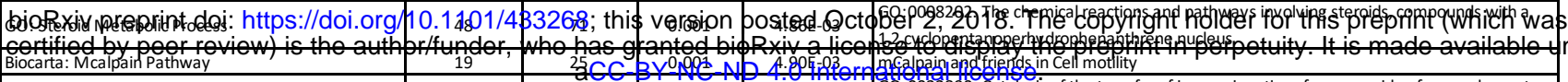 } \\
\hline $\begin{array}{l}\text { GO: Inorganic Cation Transmembrane Transporter } \\
\text { Activity }\end{array}$ & 39 & 55 & 0.001 & $4.90 \mathrm{E}-03$ & $\begin{array}{l}\mathrm{GO} 002280 \text {. Catalysis of the transfer of inorganic cations from one side of a membrane to } \\
\text { the other. Inorganic cations are atoms or small molecules with a positive charge that do not } \\
\text { contain carbon in covalent linkage. }\end{array}$ \\
\hline GO: DNA Damage Responsesignal Transduction & 23 & 33 & 0.001 & $4.91 \mathrm{E}-03$ & GO:0042770. A cascade of processes induced by the detection of DNA damage within a cell. \\
\hline KEGG: Leukocyte Transendothelial Migration & 73 & 113 & 0.002 & $5.13 \mathrm{E}-03$ & hsa04670 \\
\hline KEGG: Glycine Serine and Threonine Metabolism & 18 & 31 & 0.001 & $5.14 \mathrm{E}-03$ & hsa00260 \\
\hline $\begin{array}{l}\text { GO: Transferase Activity Transferring Sulfur } \\
\text { Containing Groups }\end{array}$ & 25 & 32 & 0.002 & $5.26 \mathrm{E}-03$ & $\begin{array}{l}\text { GO:0016782. Catalysis of the transfer of a sulfur-containing group from one compound } \\
\text { (donor) to another (acceptor). }\end{array}$ \\
\hline GO: Mitochondrial Part & 69 & 139 & 0.003 & $5.41 \mathrm{E}-03$ & $\begin{array}{l}\text { GO:0044429. Any constituent part of a mitochondrion, a semiautonomous, self replicating } \\
\text { organelle that occurs in varying numbers, shapes, and sizes in the cytoplasm of virtually all } \\
\text { eukaryotic cells. It is notably the site of tissue respiration. }\end{array}$ \\
\hline Biocarta: ECM Pathway & 19 & 24 & 0.001 & $5.44 \mathrm{E}-03$ & Erk and PI-3 Kinase Are Necessary for Collagen Binding in Corneal Epithelia \\
\hline KEGG: Phosphatidylinositol Signaling System & 50 & 76 & 0.001 & $5.58 \mathrm{E}-03$ & hsa04070 \\
\hline GO: Lipid Transporter Activity & 21 & 27 & 0.001 & $5.60 \mathrm{E}-03$ & GO:0005319. Enables the directed movement of lipids into, out of, within or between cells. \\
\hline GO: Sequence Specific DNA Binding & 41 & 58 & 0.001 & $5.63 \mathrm{E}-03$ & $\begin{array}{l}\text { GO:0043565. Interacting selectively with DNA of a specific nucleotide composition, e.g. GC- } \\
\text { rich DNA binding, or with a specific sequence motif or type of DNA e.g. promotor binding or } \\
\text { rDNA binding. }\end{array}$ \\
\hline GO: Heart Development & 26 & 37 & 0.001 & $5.66 \mathrm{E}-03$ & $\begin{array}{l}\text { GO:0007507. The process whose specific outcome is the progression of the heart over time, } \\
\text { from its formation to the mature structure. The heart is a hollow, muscular organ, which, by } \\
\text { contracting rhythmically, keeps up the circulation of the blood. }\end{array}$ \\
\hline KEGG: Glycerophospholipid Metabolism & 50 & 76 & 0.002 & $5.66 \mathrm{E}-03$ & hsa00564 \\
\hline GO: Secondary Metabolic Process & 16 & 26 & 0.001 & $5.67 \mathrm{E}-03$ & $\begin{array}{l}\text { GO:0019748. The chemical reactions and pathways resulting in many of the chemical } \\
\text { changes of compounds that are not necessarily required for growth and maintenance of } \\
\text { cells, and are often unique to a taxon. In multicellular organisms secondary metabolism is } \\
\text { generally carried out in specific cell types, and may be useful for the organism as a whole. In } \\
\text { unicellular organisms, secondary metabolism is often used for the production of antibiotics or } \\
\text { for the utilization and acauisition of unusual nutrients. }\end{array}$ \\
\hline GO: Positive Regulation of Cell Differentiation & 18 & 25 & 0.001 & $5.71 \mathrm{E}-03$ & $\begin{array}{l}\text { G0:0045597. Any process that activates or increases the frequency, rate or extent of cell } \\
\text { differentiation. }\end{array}$ \\
\hline GO: Alcohol Metabolic Process & 56 & 87 & 0.001 & $5.95 \mathrm{E}-03$ & $\begin{array}{l}\text { GO:0006066. The chemical reactions and pathways involving alcohols, any of a class of alkyl } \\
\text { compounds containing a hydroxyl group. }\end{array}$ \\
\hline GO: Response to UV & 17 & 25 & 0.001 & $6.00 \mathrm{E}-03$ & $\begin{array}{l}\text { GO:0009411. A change in state or activity of a cell or an organism (in terms of movement, } \\
\text { secretion, enzyme production, gene expression, etc.) as a result of an ultraviolet radiation } \\
\text { (UV light) stimulus. Ultraviolet radiation is electromagnetic radiation with a wavelength in } \\
\text { the range of } 10 \text { to } 380 \text { nanometers. }\end{array}$ \\
\hline GO: Gated Channel Activity & 87 & 121 & 0.001 & $6.01 \mathrm{E}-03$ & $\begin{array}{l}\text { GO:0022836. Catalysis of the transmembrane transfer of a solute by a channel that opens in } \\
\text { response to a specific stimulus. }\end{array}$ \\
\hline KEGG: Adherens Junction & 56 & 72 & 0.001 & $6.04 \mathrm{E}-03$ & hsa04520 \\
\hline KEGG: Mtor Signaling Pathway & 36 & 52 & 0.001 & $6.08 \mathrm{E}-03$ & hsa04150 \\
\hline GO: Metal Ion Transport & 81 & 115 & 0.001 & $6.10 \mathrm{E}-03$ & $\begin{array}{l}\text { GO:0030001. The directed movement of metal ions, any metal ion with an electric charge, } \\
\text { into, out of, within or between cells. }\end{array}$ \\
\hline Biocarta: Insulin Pathway & 15 & 22 & 0.001 & $6.15 \mathrm{E}-03$ & Insulin Signaling Pathway \\
\hline GO: Calcium Channel Activity & 26 & 33 & 0.001 & $6.19 \mathrm{E}-03$ & $\begin{array}{l}\text { GO:0005262. Catalysis of facilitated diffusion of an calcium (by an energy-independent } \\
\text { process) involving passage through a transmembrane aqueous pore or channel without } \\
\text { evidence for a carrier-mediated mechanism. }\end{array}$ \\
\hline GO: Fatty Acid Metabolic Process & 41 & 63 & 0.001 & $6.27 \mathrm{E}-03$ & $\begin{array}{l}\text { GO:0006631. The chemical reactions and pathways involving fatty acids, aliphatic } \\
\text { monocarboxylic acids liberated from naturally occurring fats and oils by hydrolysis. }\end{array}$ \\
\hline GO: G Protein Coupled Receptor Activity & 131 & 184 & 0.001 & $6.30 \mathrm{E}-03$ & $\begin{array}{l}\text { GO:0004930. A receptor that binds an extracellular ligand and transmits the signal to a } \\
\text { heterotrimeric G-protein complex. These receptors are characteristically seven- } \\
\text { transmembrane receptors and are made up of hetero- or homodimers. }\end{array}$ \\
\hline KEGG: TGF-Beta Signaling Pathway & 58 & 84 & 0.001 & $6.38 \mathrm{E}-03$ & hsa04350 \\
\hline GO: Protein C Terminus Binding & 48 & 73 & 0.001 & $6.40 \mathrm{E}-03$ & $\begin{array}{l}\text { GO:0008022. Interacting selectively with a protein C-terminus, the end of any peptide chain } \\
\text { at which the 1-carboxy function of a constituent amino acid is not attached in peptide linkage } \\
\text { to another amino-acid residue. }\end{array}$ \\
\hline $\begin{array}{l}\text { GO: Transmembrane Receptor Protein Tyrosine } \\
\text { Kinase Signaling Pathway }\end{array}$ & 65 & 83 & 0.001 & $7.21 \mathrm{E}-03$ & \begin{tabular}{|l|}
$\mathrm{GO}: 0007169$. The series of molecular signals generated as a consequence of a \\
transmembrane receptor tyrosine kinase binding to its physiological ligand.
\end{tabular} \\
\hline Biocarta: NOS1 Pathway & 15 & 21 & 0.001 & $7.24 \mathrm{E}-03$ & Nitric Oxide Signaling Pathway \\
\hline GO: Cell Cycle Checkpoint & 27 & 47 & 0.001 & $7.37 \mathrm{E}-03$ & $\begin{array}{l}\text { GO:0000075. A point in the eukaryotic cell cycle where progress through the cycle can be } \\
\text { halted until conditions are suitable for the cell to proceed to the next stage. }\end{array}$ \\
\hline Biocarta: Inflam Pathway & 17 & 29 & 0.002 & $7.44 \mathrm{E}-03$ & Cytokines and Inflammatory Response \\
\hline GO: G Protein Coupled Receptor Binding & 31 & 54 & 0.004 & $7.50 \mathrm{E}-03$ & GO:0001664. Interacting selectively with a G-protein-coupled receptor. \\
\hline KEGG: Glycerolipid Metabolism & 36 & 49 & 0.001 & $8.01 \mathrm{E}-03$ & hsa00561 \\
\hline GO: Activation of Protein Kinase Activity & 19 & 26 & 0.002 & $8.04 \mathrm{E}-03$ & GO:0032147. Any process that initiates the activity of an inactive protein kinase. \\
\hline GO: Glucose Metabolic Process & 17 & 28 & 0.002 & $8.28 \mathrm{E}-03$ & $\begin{array}{l}\text { GO:0006006. The chemical reactions and pathways involving glucose, the aldohexose gluco- } \\
\text { hexose. D-glucose is dextrorotatory and is sometimes known as dextrose; it is an important } \\
\text { source of energy for living organisms and is found free as well as combined in homo- and } \\
\text { hetero-oligosaccharides and polysaccharides. }\end{array}$ \\
\hline $\begin{array}{l}\text { KEGG: Glycosaminoglycan Biosynthesis Heparan } \\
\text { Sulfate }\end{array}$ & 21 & 26 & 0.001 & $8.33 \mathrm{E}-03$ & 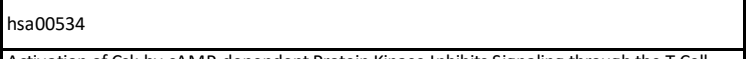 \\
\hline Biocarta: CSKPathway & 17 & 22 & 0.002 & $8.38 \mathrm{E}-03$ & $\begin{array}{l}\text { Activation of Csk by cAMP-dependent Protein Kinase Inhibits Signaling through the T Cell } \\
\text { Receptor }\end{array}$ \\
\hline KEGG: Ether Lipid Metabolism & 22 & 33 & 0.001 & $8.47 \mathrm{E}-03$ & hsa00565 \\
\hline GO: Regulation of Binding & 39 & 57 & 0.002 & $8.53 \mathrm{E}-03$ & $\begin{array}{l}\text { GO:0051098. Any process that modulates the frequency, rate or extent of binding, the } \\
\text { selective interaction of a molecule with one or more specific sites on another molecule. }\end{array}$ \\
\hline GO: Protein Kinase Inhibitor Activity & 15 & 24 & 0.001 & $8.87 \mathrm{E}-03$ & $\begin{array}{l}\text { GO:0004860. Stops, prevents or reduces the activity of a protein kinase, an enzyme which } \\
\text { phosphorylates a protein. }\end{array}$ \\
\hline KEGG: Valine Leucine and Isoleucine Degradation & 30 & 44 & 0.001 & $8.98 \mathrm{E}-03$ & hsa00280 \\
\hline GO: Muscle Development & 55 & 93 & 0.001 & $9.01 \mathrm{E}-03$ & $\begin{array}{l}\text { GO:0007517. The process whose specific outcome is the progression of the muscle over } \\
\text { time, from its formation to the mature structure. The muscle is an organ consisting of a tissue } \\
\text { made up of various elongated cells that are specialized to contract and thus to produce } \\
\text { movement and mechanical work. }\end{array}$ \\
\hline GO: Glycosaminoglycan Binding & 24 & 33 & 0.002 & $9.19 \mathrm{E}-03$ & $\begin{array}{l}\text { GO:0005539. Interacting selectively with any glycan (polysaccharide) containing a } \\
\text { substantial proportion of aminomonosaccharide residues. }\end{array}$ \\
\hline $\begin{array}{l}\text { GO: Positive Regulation of Transcription From RNA } \\
\text { Polymerase ii Promoter }\end{array}$ & 43 & 65 & 0.001 & $9.24 \mathrm{E}-03$ & $\begin{array}{l}\text { GO:0045944. Any process that activates or increases the frequency, rate or extent of } \\
\text { transcription from the RNA polymerase II promoter. }\end{array}$ \\
\hline GO: Envelope & 91 & 164 & 0.004 & $9.24 \mathrm{E}-03$ & $\begin{array}{l}\text { GO:0031975. A multilayered structure surrounding all or part of a cell; encompasses one or } \\
\text { more lipid bilayers, and may include a cell wall layer, also includes the space between layers. }\end{array}$ \\
\hline GO: Organelle Envelope & 91 & 164 & 0.004 & $9.24 \mathrm{E}-03$ & $\begin{array}{l}\text { GO:0031967. A double membrane structure enclosing an organelle, including two lipid } \\
\text { bilayers and the region between them. In some cases, an organelle envelope may have } \\
\text { more than two membranes. }\end{array}$ \\
\hline
\end{tabular}




\begin{tabular}{|c|c|c|c|c|c|}
\hline \multicolumn{6}{|c|}{ 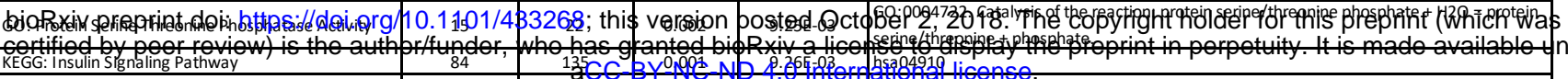 } \\
\hline Biocarta: PPATA Pathway & 41 & 57 & 0.002 & $9.28 \mathrm{E}-03$ & Mechanism of Gene Regulation by Peroxisome Proliferators via PPARa(alpha) \\
\hline GO: Negative Regulation of Cell Differentiation & 22 & 28 & 0.002 & 9.56E-03 & $\begin{array}{l}\text { GO:0045596. Any process that stops, prevents or reduces the frequency, rate or extent of } \\
\text { cell differentiation. }\end{array}$ \\
\hline Biocarta: NO1 Pathway & 22 & 30 & 0.002 & $9.81 \mathrm{E}-03$ & Actions of Nitric Oxide in the Heart \\
\hline GO: DNA Integrity Checkpoint & 14 & 23 & 0.001 & $9.92 \mathrm{E}-03$ & $\begin{array}{l}\text { GO:0031570. Any cell cycle checkpoint that delays or arrests cell cycle progression in } \\
\text { response to changes in DNA structure. }\end{array}$ \\
\hline GO: Response to Hormone Stimulus & 22 & 32 & 0.003 & $1.05 E-02$ & $\begin{array}{l}\text { GO:0009725. A change in state or activity of a cell or an organism (in terms of movement, } \\
\text { secretion, enzyme production, gene expression, etc.) as a result of a hormone stimulus. }\end{array}$ \\
\hline GO: Membrane Organization and Biogenesis & 90 & 133 & 0.003 & $1.10 \mathrm{E}-02$ & $\begin{array}{l}\text { GO:0016044. A process that is carried out at the cellular level which results in the formation, } \\
\text { arrangement of constituent parts, or disassembly of membranes inside and surrounding the } \\
\text { cell. }\end{array}$ \\
\hline GO: Negative Regulation of Transcription & 115 & 184 & 0.002 & $1.14 \mathrm{E}-02$ & $\begin{array}{l}\text { GO: } 0016481 . \text { Any process that stops, prevents or reduces the frequency, rate or extent of } \\
\text { transcription. }\end{array}$ \\
\hline GO: Contractile Fiber & 15 & 25 & 0.005 & $1.14 \mathrm{E}-02$ & $\begin{array}{l}\text { GO:0043292. Fibers, composed of actin, myosin, and associated proteins, found in cells of } \\
\text { smooth or striated muscle. }\end{array}$ \\
\hline GO: Polysaccharide Binding & 25 & 35 & 0.001 & $1.15 \mathrm{E}-02$ & GO:0030247. Interacting selectively with any polysaccharide. \\
\hline GO: Actin Filament Organization & 13 & 23 & 0.003 & $1.25 \mathrm{E}-02$ & $\begin{array}{l}\text { GO:0007015. Control of the spatial distribution of actin filaments; includes organizing } \\
\text { filaments into meshworks, bundles, or other structures, as by cross-linking. }\end{array}$ \\
\hline GO: Cellular Protein Complex Assembly & 22 & 32 & 0.004 & $1.26 \mathrm{E}-02$ & $\begin{array}{l}\text { GO:0043623. The aggregation, arrangement and bonding together of a set of components } \\
\text { to form a protein complex, occurring at the level of an individual cell. }\end{array}$ \\
\hline GO: Actin Cytoskeleton Organization and Biogenesis & 64 & 103 & 0.004 & $1.26 \mathrm{E}-02$ & $\begin{array}{l}\text { GO:0030036. A process that is carried out at the cellular level which results in the formation, } \\
\text { arrangement of constituent parts, or disassembly of cytoskeletal structures comprising actin } \\
\text { filaments and their associated proteins. }\end{array}$ \\
\hline $\begin{array}{l}\text { GO: Transforming Growth Factor Beta Receptor } \\
\text { Signaling Pathway }\end{array}$ & 27 & 36 & 0.002 & $1.27 \mathrm{E}-02$ & $\begin{array}{l}\text { GO:0007179. The series of molecular signals generated as a consequence of a transforming } \\
\text { growth factor beta receptor binding to one of its physiological ligands. }\end{array}$ \\
\hline GO: Response to Abiotic Stimulus & 52 & 83 & 0.004 & $1.27 \mathrm{E}-02$ & $\begin{array}{l}\text { GO:0009628. A change in state or activity of a cell or an organism (in terms of movement, } \\
\text { secretion, enzyme production, gene expression, etc.) as a result of an abiotic (non-living) } \\
\text { stimulus. }\end{array}$ \\
\hline GO: Regulation of Heart Contraction & 18 & 25 & 0.002 & $1.27 \mathrm{E}-02$ & $\begin{array}{l}\text { GO:0008016. Any process that modulates the frequency, rate or extent of heart contraction. } \\
\text { Heart contraction is the process by which the heart decreases in volume in a characteristic } \\
\text { way to propel blood through the body. }\end{array}$ \\
\hline GO: Transcription Coactivator Activity & 75 & 120 & 0.003 & $1.27 \mathrm{E}-02$ & $\begin{array}{l}\text { GO:0003713. The function of a transcription cofactor that activates transcription from a RNA } \\
\text { polymerase II promoter; does not bind DNA itself. }\end{array}$ \\
\hline GO: Regulation of Cell Migration & 22 & 28 & 0.003 & $1.28 \mathrm{E}-02$ & GO:0030334. Any process that modulates the frequency, rate or extent of cell migration. \\
\hline GO: Kinase Regulator Activity & 29 & 45 & 0.002 & $1.28 \mathrm{E}-02$ & $\begin{array}{l}\text { GO:0019207. Modulates the activity of a kinase, an enzyme which catalyzes of the transfer } \\
\text { of a phosphate group, usually from ATP, to a substrate molecule. }\end{array}$ \\
\hline GO: Response to Light Stimulus & 28 & 44 & 0.005 & $1.28 \mathrm{E}-02$ & $\begin{array}{l}\text { GO:0009416. A change in state or activity of a cell or an organism (in terms of movement, } \\
\text { secretion, enzyme production, gene expression, etc.) as a result of a light stimulus, } \\
\text { electromagnetic radiation of wavelengths classified as infrared, visible or ultraviolet light. }\end{array}$ \\
\hline GO: Small Protein Conjugating Enzyme Activity & 36 & 52 & 0.002 & $1.29 \mathrm{E}-02$ & $\begin{array}{l}\text { GO:0008639. Catalysis of the covalent attachment of small proteins, such as ubiquitin or } \\
\text { ubiquitin-like proteins, to lysine residues on a target protein. This function may be performed } \\
\text { alone or in conjunction with an E3, ubiquitin-like protein ligase. }\end{array}$ \\
\hline GO: Voltage Gated Channel Activity & 52 & 73 & 0.002 & $1.39 \mathrm{E}-02$ & $\begin{array}{l}\text { GO:0022832. Catalysis of the transmembrane transfer of a solute by a channel whose open } \\
\text { state is dependent on the voltage across the membrane in which it is embedded. }\end{array}$ \\
\hline GO: Mitosis & 48 & 80 & 0.004 & $1.39 \mathrm{E}-02$ & $\begin{array}{l}\text { GO:0007067. Progression through mitosis, the division of the eukaryotic cell nucleus to } \\
\text { produce two daughter nuclei that, usually, contain the identical chromosome complement to } \\
\text { their mother. }\end{array}$ \\
\hline GO: Electron Carrier Activity & 49 & 78 & 0.001 & $1.40 \mathrm{E}-02$ & $\begin{array}{l}\text { GO:0009055. Any molecular entity that serves as an electron acceptor and electron donor in } \\
\text { an electron transport system. }\end{array}$ \\
\hline KEGG: Purine Metabolism & 95 & 154 & 0.004 & $1.40 \mathrm{E}-02$ & hsa00230 \\
\hline KEGG: Fructose and Mannose Metabolism & 21 & 33 & 0.006 & $1.47 \mathrm{E}-02$ & hsa00051 \\
\hline GO: Rhodopsin Like Receptor Activity & 90 & 128 & 0.002 & $1.47 E-02$ & $\begin{array}{l}\text { GO:0001584. A G-protein coupled receptor that is structurally/functionally related to the } \\
\text { rhodopsin receptor. }\end{array}$ \\
\hline GO: Contractile Fiber Part & 14 & 23 & 0.006 & $1.52 \mathrm{E}-02$ & $\begin{array}{l}\text { GO:0044449. Any constituent part of a contractile fiber, a fiber composed of actin, myosin, } \\
\text { and associated proteins, found in cells of smooth or striated muscle. }\end{array}$ \\
\hline GO: Carbohydrate Biosynthetic Process & 39 & 49 & 0.002 & $1.53 E-02$ & $\begin{array}{l}\text { GO:0016051. The chemical reactions and pathways resulting in the formation of } \\
\text { carbohydrates, any of a group of organic compounds based of the general formula } \\
\mathrm{Cx}(\mathrm{H} 2 \mathrm{O}) \mathrm{y} \text {. }\end{array}$ \\
\hline GO: Cation Channel Activity & 83 & 118 & 0.002 & $1.55 \mathrm{E}-02$ & $\begin{array}{l}\text { GO:0005261. Catalysis of the energy-independent passage of cations across a lipid bilayer } \\
\text { down a concentration gradient. }\end{array}$ \\
\hline GO: Phosphoprotein Phosphatase Activity & 56 & 79 & 0.002 & $1.59 \mathrm{E}-02$ & $\begin{array}{l}\text { GO: } 0004721 \text {. Catalysis of the reaction: a phosphoprotein + } \mathrm{H} 2 \mathrm{O}=\text { a protein + phosphate. } \\
\text { Together with protein kinases, these enzymes control the state of phosphorylation of cell } \\
\text { proteins and thereby provide an important mechanism for regulating cellular activity. }\end{array}$ \\
\hline $\begin{array}{l}\text { KEGG: Arrhythmogenic Right Ventricular } \\
\text { Cardiomyopathy Arvc }\end{array}$ & 55 & 74 & 0.001 & $1.76 E-02$ & hsa05412 \\
\hline GO: Nuclease Activity & 30 & 55 & 0.004 & $1.77 \mathrm{E}-02$ & GO:0004518. Catalysis of the hydrolysis of ester linkages within nucleic acids. \\
\hline KEGG: Vascular Smooth Muscle Contraction & 76 & 115 & 0.003 & $1.78 \mathrm{E}-02$ & hsa04270 \\
\hline $\begin{array}{l}\text { GO: Regulation of Organelle Organization and } \\
\text { Biogenesis }\end{array}$ & 27 & 39 & 0.003 & $1.83 E-02$ & $\begin{array}{l}\text { GO:0033043. Any process that modulates the frequency, rate or extent of the processes } \\
\text { involved in the formation, arrangement of constituent parts, or disassembly of an organelle. }\end{array}$ \\
\hline Biocarta: Ceramide Pathway & 17 & 22 & 0.005 & $1.85 \mathrm{E}-02$ & Ceramide Signaling Pathway \\
\hline GO: Mitochondrial Envelope & 46 & 94 & 0.005 & $1.86 \mathrm{E}-02$ & $\begin{array}{l}\text { GO:0005740. The double lipid bilayer enclosing the mitochondrion and separating its } \\
\text { contents from the cell cytoplasm; includes the intermembrane space. }\end{array}$ \\
\hline GO: Mitochondrial Lumen & 24 & 46 & 0.006 & $1.89 \mathrm{E}-02$ & GO:0031980. The volume enclosed by the mitochondrial inner membrane. \\
\hline GO: Mitochondrial Matrix & 24 & 46 & 0.006 & $1.89 \mathrm{E}-02$ & $\begin{array}{l}\text { GO:0005759. The gel-like material, with considerable fine structure, that lies in the matrix } \\
\text { space, or lumen, of a mitochondrion. It contains the enzymes of the tricarboxylic acid cycle } \\
\text { and, in some organisms, the enzymes concerned with fatty-acid oxidation. }\end{array}$ \\
\hline KEGG: Sphingolipid Metabolism & 27 & 40 & 0.008 & $2.02 \mathrm{E}-02$ & hsa00600 \\
\hline GO: Excretion & 23 & 36 & 0.006 & 2.06E-02 & $\begin{array}{l}\text { GO:0007588. The elimination by an organism of the waste products that arise as a result of } \\
\text { metabolic activity. These products include water, carbon dioxide ( } \mathrm{CO} 2) \text {, and nitrogenous } \\
\text { compounds. }\end{array}$ \\
\hline $\begin{array}{l}\text { GO: Positive Regulation of Multicellular Organismal } \\
\text { Process }\end{array}$ & 43 & 64 & 0.003 & 2.06E-02 & $\begin{array}{l}\text { GO:0051240. Any process that activates or increases the frequency, rate or extent of an } \\
\text { organismal process, the processes pertinent to the function of an organism above the cellular } \\
\text { level; includes the integrated processes of tissues and organs. }\end{array}$ \\
\hline GO: Regulation of Mitosis & 25 & 40 & 0.006 & $2.08 \mathrm{E}-02$ & GO:0007088. Any process that modulates the frequency, rate or extent of mitosis. \\
\hline KEGG: Progesterone Mediated Oocyte Maturation & 53 & 84 & 0.004 & $2.11 \mathrm{E}-02$ & hsa04914 \\
\hline KEGG: Long Term Depression & 52 & 70 & 0.002 & $2.21 \mathrm{E}-02$ & hsa04730 \\
\hline GO: Monovalent Inorganic Cation Transport & 62 & 90 & 0.004 & $2.21 \mathrm{E}-02$ & $\begin{array}{l}\text { GO:0015672. The directed movement of inorganic cations with a valency of one into, out of, } \\
\text { within or between cells. Inorganic cations are atoms or small molecules with a positive } \\
\text { charge which do not contain carbon in covalent linkage. }\end{array}$ \\
\hline KEGG: Dorso Ventral Axis formation & 20 & 24 & 0.003 & $2.22 \mathrm{E}-02$ & hsa04320 \\
\hline GO: Growth & 50 & 76 & 0.004 & $2.22 \mathrm{E}-02$ & $\begin{array}{l}\text { GO:0040007. The increase in size or mass of an entire organism, a part of an organism or a } \\
\text { cell. }\end{array}$ \\
\hline
\end{tabular}




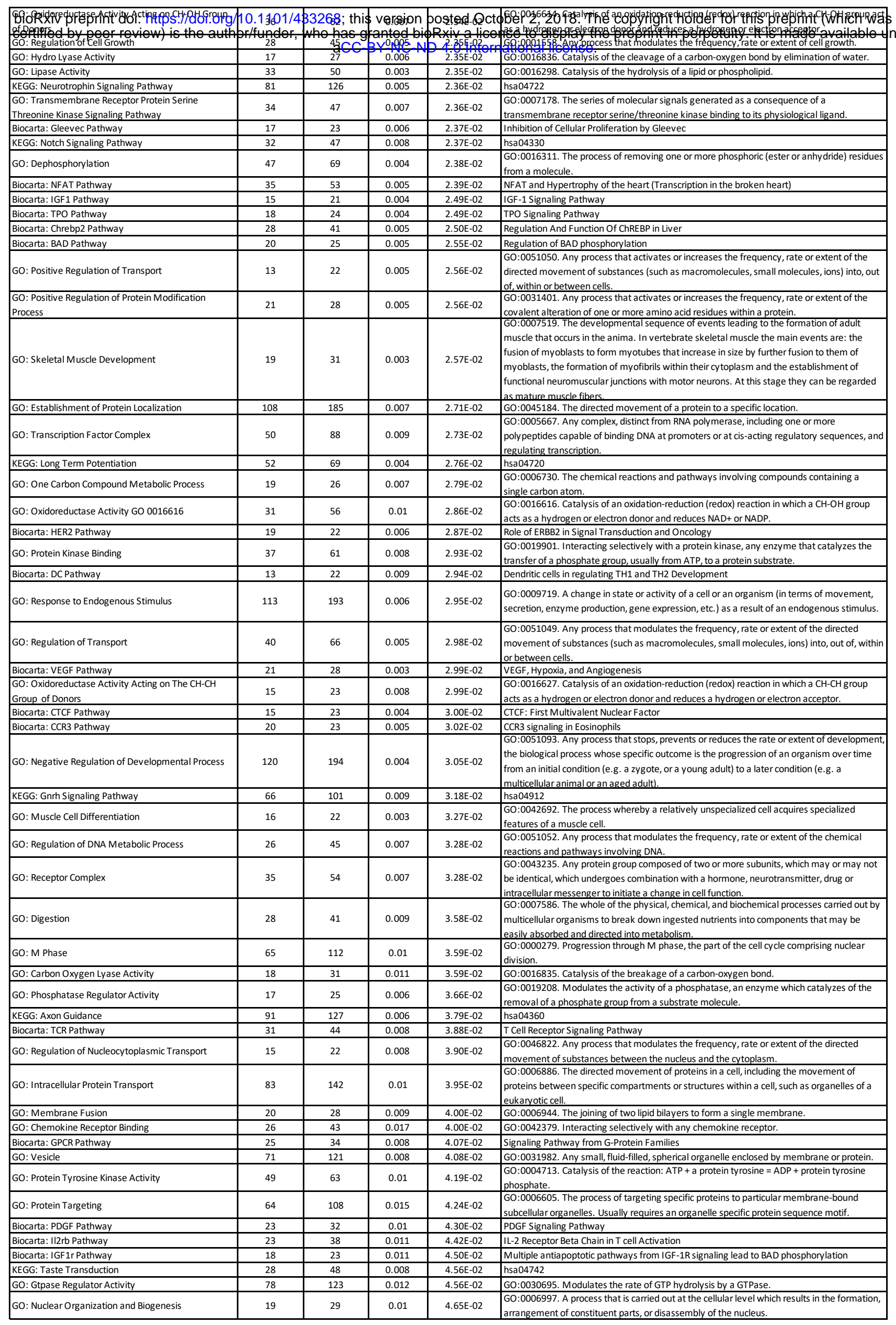




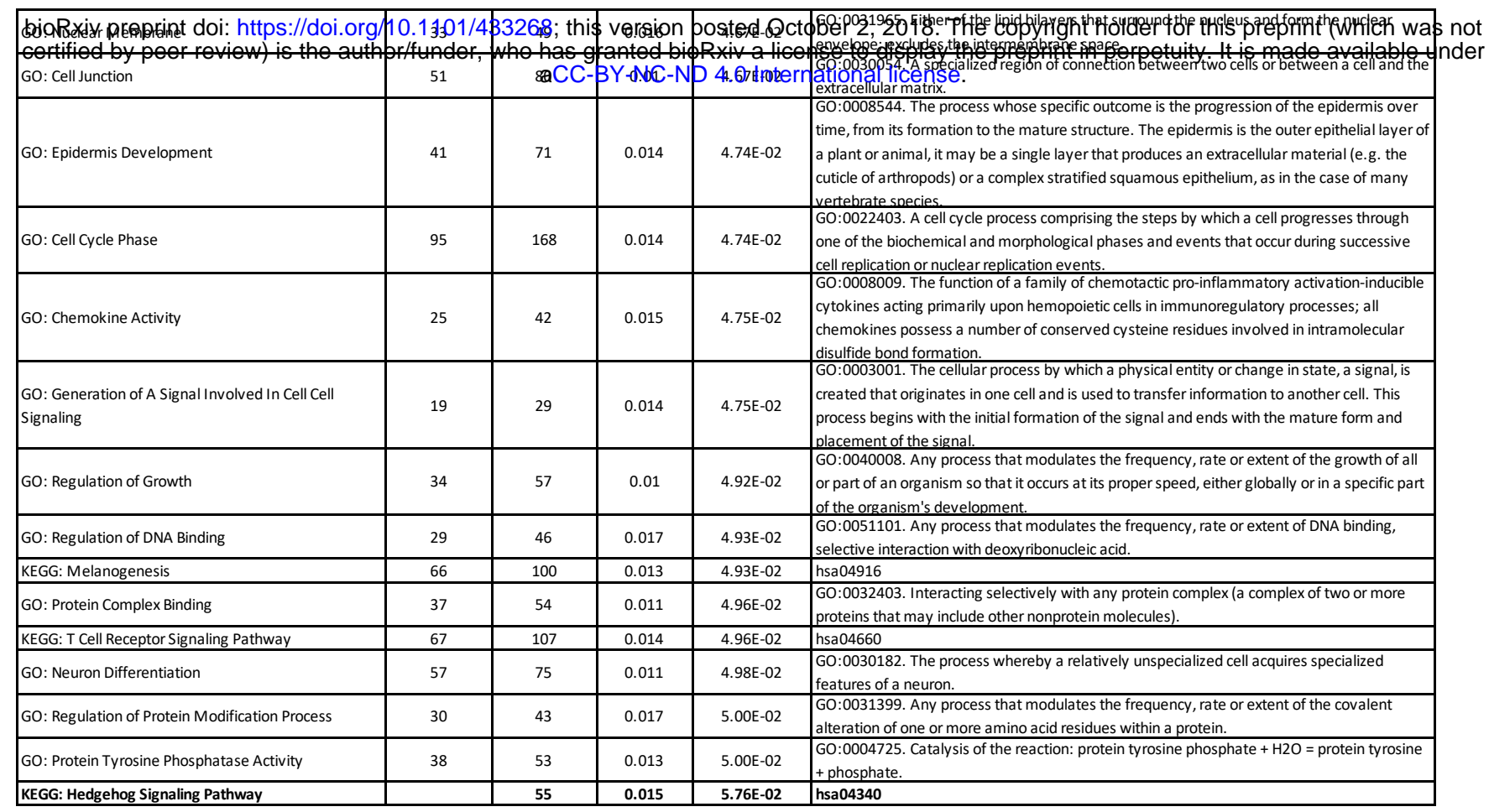


bioRxiv preprint doi: https://doi.org/10.1101/433268; this version posted October 2, 2018. The copyright holder for this preprint (which was not

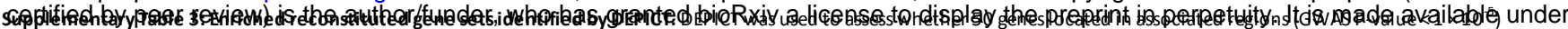
were enriched for any of the reconstituted gene sets defined by DEPACG.W

0.01 ). For each cluster we provide all gene sets that contribute to this cluster and were nominally enriched ( $P$-value $<0.05)$. Associated regions were constructed by mapping genes to a given region if the genes resided within, or overlapped with linkage disequilibrium $(r 2>0.5)$ flanks of a given lead SNP. Ex: Cluster ID and cluster center was defined by Affinity Propagation method which was used to cluster gene sets that were highly correlated and automatically defines independent clusters based on calculated Pearson's correlation matrix (See methods for dertails). The central gene set of a given cluster is the most significant gene set in that cluster (bold). We provide the list of genes near associated loci allocated to each gene set and their respective likelihood to be part of each gene set. We only provide genes with significant likelihood |z-score| $>1.96$ corresponding to P-value $<0.05$. NA: not available, is indicated for gene sets for which no gene presented a significant z-score.

\begin{tabular}{|c|c|c|c|c|c|c|}
\hline $\begin{array}{l}\text { Cluster } \\
\text { ID }\end{array}$ & Gene set ID & Gene set Name & $\begin{array}{l}\text { Central gene set of the } \\
\text { cluster }\end{array}$ & $\begin{array}{l}\text { Most significant } \\
\text { gene set }\end{array}$ & P value & Genes at associated loci contributing to gene sets \\
\hline 1 & MP:0010300 & $\begin{array}{l}\text { Increased skin tumor } \\
\text { incidence }\end{array}$ & \multirow{4}{*}{ Intestinal adenocarcinoma } & \multirow{4}{*}{$\begin{array}{l}\text { Increased skin tumor } \\
\text { incidence }\end{array}$} & 0.0001 & 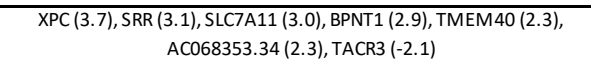 \\
\hline 1 & MP:0002957 & Intestinal adenocarcinoma & & & 0.001 & FOXL1 (2.5), SLFN11 (2.5), AC068353.34 (2.2), UFL1 (-2.6) \\
\hline 1 & ENSG00000138180 & CEP55 PPI subnetwork & & & 0.02 & AL450226.1(2.2) \\
\hline 1 & MP:0002404 & $\begin{array}{l}\text { Increased intestinal } \\
\text { adenoma incidence }\end{array}$ & & & 0.02 & $\begin{array}{l}\operatorname{SRR}(3.2), \operatorname{CAND2}(2.8), \operatorname{XPC}(2.7), \operatorname{RASSF} 3(2.2), \operatorname{AC068353.34}(2.1), \\
\quad \text { FOXL1 (2.0), LINC00973 (2.0), AL450226.1 (2.0), AKR1C3 (-2.4) }\end{array}$ \\
\hline 2 & GO:0030684 & Preribosome & \multirow{5}{*}{ FLG2 PPI subnetwork } & \multirow{5}{*}{ Preribosome } & 0.0004 & $\operatorname{TSR} 1(3.6), \operatorname{SETD} 4(3.2), \operatorname{ERCC} 4(2.2), \operatorname{SRR}(-2.3)$ \\
\hline \multirow[t]{2}{*}{2} & ENSG00000065268 & WDR18 PPI subnetwork & & & 0.004 & SMG6 (3.1), TSR1 (2.9), SLFN11 (2.4), RUNX1 (-2.3) \\
\hline & & & & & & \\
\hline 2 & ENSG00000143520 & FLG2 PPI subnetwork & & & 0.03 & TSR1 (3.0), SMG6 (3.0) \\
\hline 2 & ENSG00000136021 & SCYL2 PPI subnetwork & & & 0.04 & LINC02064 (2.6), RP1L1 (2.2), PEAK1 (-2.4) \\
\hline 3 & MP:0001689 & $\begin{array}{l}\text { Incomplete somite } \\
\text { formation }\end{array}$ & & & 0.0004 & PTPRM (3.3), LINC00312 (-2.6) \\
\hline 3 & GO:0045766 & $\begin{array}{l}\text { Positive regulation of } \\
\text { angiogenesis }\end{array}$ & & & 0.0006 & $\operatorname{LMCD1}(2.3), \operatorname{LINC00312~(2.2)~}$ \\
\hline 3 & MP:0001614 & $\begin{array}{l}\text { Abnormal blood vessel } \\
\text { morphology }\end{array}$ & & & 0.0009 & LMCD1 (2.5), PEAK1 (2.5), PTPRM (2.4), FHL5 (2.0) \\
\hline 3 & MP:0004787 & $\begin{array}{l}\text { Abnormal dorsal aorta } \\
\text { morphology }\end{array}$ & & & 0.007 & $\operatorname{PTPRM}(2.9), \operatorname{RASSF} 3(2.8), \operatorname{LMCD} 1(2.0), \operatorname{SEZ6L}(-2.3)$ \\
\hline 3 & ENSG00000087303 & NID2 PPI subnetwork & & & 0.009 & PEAK1 (2.7), PTPRM (2.3), LMCD1 (2.1) \\
\hline 3 & MP:0006126 & $\begin{array}{l}\text { Abnormal outflow tract } \\
\text { development }\end{array}$ & & & 0.01 & $\operatorname{LINC01013}(2.0), \operatorname{ERCC} 4(-2.1)$ \\
\hline 3 & GO:0001570 & Vasculogenesis & & & 0.01 & $\begin{array}{l}\text { FOXL1 (4.0), PTPRM (2.9), RASSF3 (2.9), UBTD1 (2.4), FHL5 (2.4), } \\
\text { LINC01648 (2.0), AC004944.1 (2.0) }\end{array}$ \\
\hline 3 & MP:0008803 & $\begin{array}{l}\text { Abnormal placental } \\
\text { labyrinth vasculature }\end{array}$ & & & 0.01 & RASSF3 (2.2), FOXL1 (2.1), PTPRM (2.0), LINC00299 (2.0) \\
\hline 3 & MP:0004251 & Failure of heart looping & & & 0.02 & $\begin{array}{l}\text { SMG6 (2.8), PBX1 (2.7), RASSF3 (2.5), CAND2 (2.3), PIEZO1 (2.3), } \\
\text { PEAK1 (2.1), RAB3GAP2 (2.1), FHL5 (-2.0), LINC00312 (-2.7) }\end{array}$ \\
\hline 3 & ENSG00000142798 & HSPG2 PPI subnetwork & & & 0.02 & PTPRM (2.8), PEAK1 (2.6), LMCD1 (2.5), MN1 (2.5), TACR3 (2.2) \\
\hline 3 & MP:0010392 & $\begin{array}{l}\text { Prolonged qrs complex } \\
\text { duration }\end{array}$ & & & 0.02 & PEAK1 (2.6) \\
\hline 3 & MP:0000272 & $\begin{array}{l}\text { Abnormal aorta } \\
\text { morphology }\end{array}$ & & & 0.02 & $\begin{array}{l}\text { LMCD1 (3.9), LINC01013 (2.6), PEAK1 (2.5), LINC00312 (2.5), } \\
\text { LINC00299 (2.2), SETD4 (2.1), HMG2OA (2.0), UBTD1 (-2.1), TMEM40 }\end{array}$ \\
\hline 3 & ENSG00000109072 & SEBOX PPI subnetwork & & & 0.02 & $\operatorname{LMCD} 1$ (2.6), FOXL1 (2.3), LINC00973 (2.2), TACR3 (2.0) \\
\hline 3 & MP:0005592 & $\begin{array}{l}\text { Abnormal vascular smooth } \\
\text { muscle morphology }\end{array}$ & Vasculature development & Incomplete somite & 0.02 & $\begin{array}{l}\text { LMCD1 (4.1), RASSF3 (3.9), FHL5 (3.4), PTPRM (3.2), UBTD1 (2.0), } \\
\text { FOXL1 (2.0) }\end{array}$ \\
\hline 3 & MP:0010856 & $\begin{array}{l}\text { Dilated respiratory } \\
\text { conducting tubes }\end{array}$ & & & 0.03 & $\operatorname{RUNX1}(2.3), \operatorname{FOXL1}(2.3), \operatorname{PEAK1}(2.0)$ \\
\hline 3 & GO:0045785 & $\begin{array}{l}\text { Positive regulation of cell } \\
\text { adhesion }\end{array}$ & & & 0.03 & $\begin{array}{l}\text { AC004944.1 (3.1), PEAK1 (3.0), LMCD1 (2.6), LINC01648 (2.5), } \\
\text { AL450226.1 (2.3), LINC00973 (2.0), CAND2 (-2.0) }\end{array}$ \\
\hline 3 & ENSG00000128052 & KDR PPI subnetwork & & & 0.03 & $\begin{array}{l}\text { PTPRM (3.1), RAB3GAP2 (2.9), FHL5 (2.6), UBTD1 (2.3), LINC00973 } \\
\text { (2.1) }\end{array}$ \\
\hline 3 & ENSG00000182492 & BGN PPI subnetwork & & & 0.03 & LMCD1 (2.8), AL450226.1 (2.4) \\
\hline 3 & GO:0048514 & $\begin{array}{l}\text { Blood vessel } \\
\text { morphogenesis }\end{array}$ & & & 0.03 & $\begin{array}{l}\text { LMCD1 (3.6), UBTD1 (3.2), PTPRM (3.0), LINC00312 (2.8), PEAK1 (2.8), } \\
\text { FHL5 (2.7) }\end{array}$ \\
\hline 3 & MP:0003071 & $\begin{array}{l}\text { Decreased vascular } \\
\text { permeability }\end{array}$ & & & 0.04 & PTPRM (3.6), FHL5 (3.4), LINC01013 (2.8), SLFN11 (2.2) \\
\hline 3 & GO:0001525 & Angiogenesis & & & 0.04 & $\begin{array}{l}\text { LMCD1 (3.5), UBTD1 (3.2), PEAK1 (2.8), FHL5 (2.7), LINC00312 (2.6), } \\
\text { PTPRM (2.4), AC004944.1 (-2.1) }\end{array}$ \\
\hline 3 & $\begin{array}{l}\text { KEGG DORSO VENTRAL } \\
\text { AXIS FORMATION }\end{array}$ & $\begin{array}{l}\text { Kegg dorso ventral axis } \\
\text { formation }\end{array}$ & & & 0.04 & $\begin{array}{l}\text { PEAK1 (3.3), FOXL1 (3.1), PTPRM (2.4), MN1 (2.3), RASSF3 (2.1), FHL5 } \\
\text { (2.0) }\end{array}$ \\
\hline 3 & GO:0044319 & $\begin{array}{l}\text { Wound healing, spreading } \\
\text { of cells }\end{array}$ & & & 0.04 & LINC02064 (2.4), LINC01013 (2.3), UBTD1 (2.1) \\
\hline 3 & GO:0001944 & Vasculature development & & & 0.04 & $\begin{array}{l}\operatorname{LMCD} 1 \text { (3.6), PEAK1 (3.2), UBTD1 (2.9), PTPRM (2.8), LINC00312 (2.6), } \\
\text { FHL5 (2.3), FOXL1 (2.0) }\end{array}$ \\
\hline 3 & GO:0001945 & Lymph vessel development & & & 0.04 & $\begin{array}{l}\text { LINC01921 (3.1), FHL5 (3.0), UBTD1 (2.5), FOXL1 (2.5), AC004944.1 } \\
(2.2)\end{array}$ \\
\hline 3 & GO:0032403 & Protein complex binding & & & 0.04 & RUNX1 (2.9), PTPRM (2.8) \\
\hline 3 & GO:0001568 & Blood vessel development & & & 0.04 & $\begin{array}{l}\operatorname{LMCD} 1 \text { (3.5), PEAK1 (3.2), PTPRM (2.9), UBTD1 (2.9), LINC00312 (2.8), } \\
\operatorname{FHL5~(2.2),~FOXL1~(2.0)~}\end{array}$ \\
\hline 3 & MP:0004921 & Decreased placenta weight & & & 0.04 & PIEZO1 (3.0), TMEM40 (2.4), TRIB1 (2.1) \\
\hline 4 & GO:0048661 & $\begin{array}{l}\text { Positive regulation of } \\
\text { smooth muscle cell }\end{array}$ & & & 0.0006 & $\begin{array}{l}\text { LINC00312 (3.7), FHL5 (3.6), LINC01648 (2.6), LMCD1 (2.2), PTPRM } \\
\text { (2.1), ANKRD20A11P (2.1), TRIB1 (2.0) }\end{array}$ \\
\hline 4 & GO:0033002 & Muscle cell proliferation & & & 0.004 & $\begin{array}{l}\text { FHL5 (3.1), LMCD1 (2.8), LINC00312 (2.7), FOXL1 (2.6), PTPRM (2.3), } \\
\operatorname{AC068353.34~(2.0),~ANKRD20A11P~(2.0),~CBR1~(-2.2)~}\end{array}$ \\
\hline 4 & GO:0048660 & $\begin{array}{l}\text { Regulation of smooth } \\
\text { muscle cell proliferation }\end{array}$ & Regulation of smooth & Positive regulation of & 0.01 & $\begin{array}{l}\text { FHL5 (3.8), LINCO0312 (3.5), PTPRM (2.4), LMCD1 (2.3), } \\
\text { ANKRD20A11P (2.2) }\end{array}$ \\
\hline 4 & GO:0048659 & $\begin{array}{l}\text { Smooth muscle cell } \\
\text { proliferation }\end{array}$ & muscle cell proliferation & $\begin{array}{l}\text { smootn muscie cell } \\
\text { proliferation }\end{array}$ & 0.01 & $\begin{array}{l}\text { FHL5 (4.0), LINC00312 (3.1), ANKRD20A11P (2.3), PTPRM (2.3), } \\
\text { LMCD1 (2.0) }\end{array}$ \\
\hline
\end{tabular}




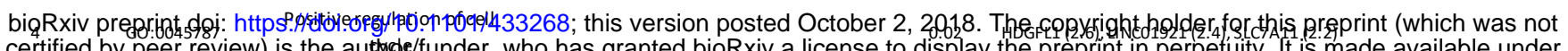
certified by peer review) is the authde/funder, who has granted bioRxiv a license to display the preprint in perpetuity. It is made available under

\begin{tabular}{|c|c|c|c|c|c|c|}
\hline 4 & ENSG00000071539 & TRIP13 PPI subnetwork & 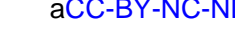 & - & 6.62 & AKR1C3 (3.3), LINC00312 (2.0), SIPA1L1 (-2.0) \\
\hline 5 & MP:0002747 & $\begin{array}{l}\text { Abnormal aortic valve } \\
\text { morphology }\end{array}$ & & & 0.0006 & $\begin{array}{l}\text { LINC00299 (2.2), SLFN11 (2.1), TRIB1 (2.1), LINC00312 (2.1), } \\
\text { AC068353.34 (2.0), RUNX1 (2.0), CBR1 (-2.1) }\end{array}$ \\
\hline 5 & MP:0002746 & $\begin{array}{l}\text { Abnormal semilunar valve } \\
\text { morphology }\end{array}$ & Abnormal semilunar valve & Abnormal aortic valve & 0.007 & LMCD1 (3.5), PTPRM (3.0), RUNX1 (2.6), LINC00312 (2.3), GLIS1 (2.0) \\
\hline 5 & MP:0005269 & $\begin{array}{l}\text { Abnormal occipital bone } \\
\text { morphology }\end{array}$ & morphology & morphology & 0.02 & GLIS1 (2.9), SIPA1L1 (2.8), FOXL1 (2.0), RAB3GAP2 (-2.2) \\
\hline 5 & MP:0002754 & $\begin{array}{c}\text { Dilated heart right } \\
\text { ventricle }\end{array}$ & & & 0.02 & LMCD1 (5.9), LINC00312 (4.1), FHL5 (2.5), PTPRM (2.4), PEAK1 (2.0) \\
\hline 6 & MP:0008840 & $\begin{array}{l}\text { Abnormal spike wave } \\
\text { discharge }\end{array}$ & & & 0.0006 & ANKRD20A11P (2.6), SEZ6L (2.3) \\
\hline 6 & MP:0003990 & $\begin{array}{l}\text { Decreased } \\
\text { neurotransmitter release }\end{array}$ & & & 0.005 & $\begin{array}{l}\text { NRXN3 (3.0), ABLIM2 (2.7), SEZ6L (2.6), PTPRM (2.1), MN1 (2.1), FHL5 } \\
\text { (2.0) }\end{array}$ \\
\hline 6 & MP:0003063 & Increased coping response & Voltage-gated calcium & Abnormal spike wave & 0.02 & $\begin{array}{l}\text { ANKRD20A11P (3.1), GLIS1 (2.8), CAND2 (2.5), NRXN3 (2.5), SIPA1L1 } \\
(2.1), \text { MN1 (2.1), LINC00312 (-2.0) }\end{array}$ \\
\hline 6 & GO:0005245 & $\begin{array}{l}\text { Voltage-gated calcium } \\
\text { channel activity }\end{array}$ & channel activity & discharge & 0.03 & $\begin{array}{l}\text { ABLIM2 (3.2), SEZ6L (2.8), MN1 (2.3), ANKRD20A11P (2.2), NRXN3 } \\
(2.2), \text { XPC (-2.0) }\end{array}$ \\
\hline 6 & GO:0007628 & Adult walking behavior & & & 0.04 & $\operatorname{NRXN3}(2.7), \operatorname{TACR3}(2.4), \operatorname{LINC01648}(2.2), \operatorname{AC004944.1}(2.0)$ \\
\hline 6 & GO:0051924 & $\begin{array}{c}\text { Regulation of calcium ion } \\
\text { transport }\end{array}$ & & & 0.04 & LINC00299 (2.3), ANKRD20A11P (2.2), ABLIM2 (2.1) \\
\hline 7 & MP:0009409 & $\begin{array}{l}\text { Abnormal skeletal muscle } \\
\text { fiber type ratio }\end{array}$ & & & 0.0006 & CAND2 (3.5), ABLIM2 (2.6), LINC01648 (2.3) \\
\hline 7 & MP:0000005 & Increased brown adipose & & & 0.01 & FOXL1 (3.1), FHL5 (2.7) \\
\hline 7 & MP:0009404 & $\begin{array}{l}\text { Centrally nucleated } \\
\text { skeletal muscle fibers }\end{array}$ & & & 0.01 & CAND2 (4.1), LMCD1 (2.5), UBTD1 (2.0) \\
\hline 7 & MP:0002841 & $\begin{array}{l}\text { Impaired skeletal muscle } \\
\text { contractility }\end{array}$ & & & 0.01 & CAND2 (4.8), ABLIM2 (4.4), LMCD1 (2.1), RP1L1 (2.0) \\
\hline 7 & MP:0004091 & Abnormal zlines & & & 0.01 & CAND2 (3.2), UBTD1 (2.2), ABLIM2 (2.1), LMCD1 (2.0) \\
\hline 7 & MP:0000747 & Muscle weakness & Abnormal skeletal muscle & Abnormal skeletal & 0.01 & ABLIM2 (2.7), CAND2 (2.4) \\
\hline 7 & MP:0004087 & $\begin{array}{l}\text { Abnormal muscle fiber } \\
\text { morphology }\end{array}$ & fiber morphology & muscle fiber type ratio & 0.02 & $\begin{array}{l}\text { RUNX1 (3.7), MN1 (3.4), LMCD1 (3.2), LINC00312 (2.7), CAND2 (2.4), } \\
\operatorname{AKR1C3~(2.0),~SRR~(-2.0),~SETD4~(-2.2)~}\end{array}$ \\
\hline 7 & MP:0002279 & $\begin{array}{l}\text { Abnormal diaphragm } \\
\text { morphology }\end{array}$ & & & 0.02 & $\begin{array}{l}\text { LMCD1 (4.5), CAND2 (3.2), MN1 (2.4), RUNX1 (2.3), PIEZO1 (2.2), } \\
\text { UBTD1 (2.1) }\end{array}$ \\
\hline 7 & MP:0000748 & $\begin{array}{l}\text { Progressive muscle } \\
\text { weakness }\end{array}$ & & & 0.02 & LMCD1 (2.8), PEAK1 (2.3), IARS2 (2.2), UBTD1 (2.0) \\
\hline 7 & MP:0003084 & $\begin{array}{l}\text { Abnormal skeletal muscle } \\
\text { fiber morphology }\end{array}$ & & & 0.03 & $\begin{array}{l}\text { CAND2 (3.7), LMCD1 (3.5), UBTD1 (2.9), PIEZO1 (2.5), ABLIM2 (2.4), } \\
\text { LINC00312 (2.0) }\end{array}$ \\
\hline 7 & MP:0009400 & $\begin{array}{l}\text { Decreased skeletal muscle } \\
\text { fiber size }\end{array}$ & & & 0.04 & TRIB1 (3.0), LMCD1 (2.8), ABLIM2 (2.6), CAND2 (2.6), LINC00312 (2.0) \\
\hline 7 & MP:0002332 & $\begin{array}{c}\text { Abnormal exercise } \\
\text { endurance }\end{array}$ & & & 0.04 & $\begin{array}{l}\text { LMCD1 (3.8), LINC00312 (3.5), TRIB1 (2.8), ABLIM2 (2.2), CAND2 (2.1), } \\
\text { CBR1 (2.0), SRR (-2.2) }\end{array}$ \\
\hline 8 & ENSG00000093167 & LRRFIP2 PPI subnetwork & & & 0.0009 & SMG6 (3.5), AC068353.34 (2.7), LINC00973 (2.4), TMEM40 (2.3) \\
\hline 8 & ENSG00000166033 & HTRA1 PPI subnetwork & & & 0.007 & $\begin{array}{l}\text { LMCD1 (4.5), AC068353.34 (3.1), PEAK1 (2.2), GLIS1 (2.0), FOXL1 } \\
(2.0)\end{array}$ \\
\hline 8 & ENSG00000171992 & SYNPO PPI subnetwork & & & 0.01 & AC068353.34 (2.8), SMG6 (2.6), LMCD1 (2.1), ANKRD20A11P (2.1) \\
\hline 8 & ENSG00000197321 & SVIL PPI subnetwork & & & 0.01 & AC068353.34 (3.4), AKR1C3 (2.2), ANKRD20A11P (2.1), TMEM40 (2.1) \\
\hline 8 & ENSG00000106028 & SSBP1 PPI subnetwork & & & 0.01 & SMG6 (3.5), LMCD1 (3.1), AC068353.34 (2.4), PEAK1 (2.3) \\
\hline 8 & ENSG00000167657 & DAPK3 PPI subnetwork & & & 0.02 & LMCD1 (3.0) \\
\hline 8 & ENSG00000196586 & MYO6 PPI subnetwork & & & 0.02 & PEAK1 (2.7), SMG6 (2.6), LMCD1 (2.4), SEZ6L (2.3), TMEM40 (2.1) \\
\hline 8 & ENSG00000134184 & GSTM1 PPI subnetwork & & & 0.02 & $\begin{array}{l}\text { AC068353.34 (2.9), ANKRD20A11P (2.5), SMG6 (2.3), LMCD1 (2.2), } \\
\text { AKR1C3 (2.2) }\end{array}$ \\
\hline 8 & ENSG00000071909 & MYO3B PPI subnetwork & & & 0.02 & AC068353.34 (2.8), LMCD1 (2.4), ANKRD20A11P (2.2), AKR1C3 (2.0) \\
\hline 8 & ENSG00000105357 & MYH14 PPI subnetwork & GSTM1 PPI subnetwork & $\begin{array}{l}\text { LRRFIP2 PPI } \\
\text { subnetwork }\end{array}$ & 0.02 & LMCD1 (3.0), ANKRD20A11P (2.7), AC068353.34 (2.6), SMG6 (2.0) \\
\hline 8 & ENSG00000198467 & TPM2 PPI subnetwork & & & 0.02 & LMCD1 (4.4), AC068353.34 (2.5), SMG6 (2.2), LINC01013 (-2.2) \\
\hline 8 & ENSG00000134202 & GSTM3 PPI subnetwork & & & 0.02 & $\begin{array}{l}\text { SMG6 (3.1), AC068353.34 (3.0), FOXL1 (2.6), LMCD1 (2.6), RASSF3 } \\
\text { (2.6), PEAK1 (2.4), ABLIM2 (2.1), LINC01013 (-2.5) }\end{array}$ \\
\hline 8 & ENSG00000100014 & SPECC1L PPI subnetwork & & & 0.02 & ANKRD20A11P (2.7), AKR1C3 (2.6), AC068353.34 (2.1), SMG6 (2.1) \\
\hline 8 & ENSG00000110880 & CORO1C PPI subnetwork & & & 0.03 & $\begin{array}{l}\text { SMG6 (2.4), AC068353.34 (2.1), LMCD1 (2.0), AKR1C3 (2.0), } \\
\text { ANKRD20A11P (2.0) }\end{array}$ \\
\hline 8 & ENSG00000101331 & $\begin{array}{l}\text { C20ORF160 PPI } \\
\text { subnetwork }\end{array}$ & & & 0.03 & $\operatorname{LMCD1}(2.3), \operatorname{AC068353.34~(2.2),~SMG6~(2.2),~RASSF3~(2.0)~}$ \\
\hline 8 & ENSG00000120265 & PCMT1 PPI subnetwork & & & 0.03 & GLIS1 (2.5), PEAK1 (2.0) \\
\hline 8 & ENSG00000006747 & SCIN PPI subnetwork & & & 0.04 & SLC7A11 (2.3), LMCD1 (2.3), SMG6 (2.3), AC068353.34 (2.1) \\
\hline 8 & ENSG00000128487 & SPECC1 PPI subnetwork & & & 0.04 & $\begin{array}{l}\text { LMCD1 (2.5), RASSF3 (2.2), SMG6 (2.1), AC068353.34 (2.1), PTPRM } \\
(2.0)\end{array}$ \\
\hline 8 & ENSG00000204361 & FAM55B PPI subnetwork & & & 0.04 & AC068353.34 (2.1), LMCD1 (2.1), LINC01648 (-2.0) \\
\hline 9 & GO:0034405 & $\begin{array}{l}\text { Response to fluid shear } \\
\text { stress }\end{array}$ & & & 0.001 & $\begin{array}{l}\text { PIEZO1 (3.1), ERCC4 (2.6), AL450226.1 (2.5), LINC02064 (2.5), } \\
\text { LINC01921 (2.1), LMCD1 (2.1), RASSF3 (2.0), LINC01648 (2.0) }\end{array}$ \\
\hline 9 & ENSG00000139567 & ACVRL1 PPI subnetwork & & & 0.003 & RASSF3 (2.1), RUNX1 (2.0) \\
\hline 9 & ENSG00000198742 & SMURF1 PPI subnetwork & & & 0.008 & HMG2OA (3.7), PBX1 (2.7), LINC00312 (2.2) \\
\hline 9 & GO:0060389 & $\begin{array}{l}\text { Pathway-restricted smad } \\
\text { protein phosphorylation }\end{array}$ & & & 0.009 & LINC02064 (3.2), LMCD1 (2.3), GLIS1 (2.0), SRR (-2.0), TMEM40 (-2.2) \\
\hline
\end{tabular}




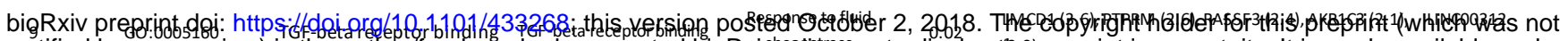
certified by peer review) is the author/funder, who has granted bioRxishatifteresse to display the) preprint in perpetuity. It is made available under

9 ENSG00000120693 SMAD9 PPI subnetwork aCC-BY-NC-ND 4.0 International bịgęnse ${ }_{\text {GFLL }}(2.3)$, TRIB1 (2.1)

\begin{tabular}{|c|c|c|c|c|}
\hline 9 & ENSG00000163513 & TGFBR2 PPI subnetwork & & \\
\hline 9 & ENSG00000123612 & ACVR1C PPI subnetwork & & \\
\hline 9 & GO:0017015 & $\begin{array}{l}\text { Regulation of transforming } \\
\text { growth factor beta }\end{array}$ & & \\
\hline 10 & MP:0000223 & $\begin{array}{c}\text { Decreased monocyte cell } \\
\text { number }\end{array}$ & \multirow{11}{*}{$\begin{array}{l}\text { Impaired neutrophil } \\
\text { chemotaxis }\end{array}$} & \multirow{11}{*}{$\begin{array}{l}\text { Decreased monocyte } \\
\text { cell number }\end{array}$} \\
\hline 10 & MP:0002465 & $\begin{array}{l}\text { Abnormal eosinophil } \\
\text { physiology } \\
\text { Calcium-dependent }\end{array}$ & & \\
\hline 10 & GO:0005544 & phospholipid binding & & \\
\hline 10 & $\begin{array}{l}\text { REACTOME } \\
\text { PROSTANOID }\end{array}$ & $\begin{array}{l}\text { Reactome prostanoid } \\
\text { metabolism }\end{array}$ & & \\
\hline 10 & ENSG00000196415 & PRTN3 PPI subnetwork & & \\
\hline 10 & ENSG00000101336 & HCK PPI subnetwork & & \\
\hline 10 & MP:0000219 & $\begin{array}{l}\text { Increased neutrophil cell } \\
\text { number }\end{array}$ & & \\
\hline 10 & ENSG00000138032 & PPM1B PPI subnetwork & & \\
\hline 10 & MP:0008720 & $\begin{array}{l}\text { Impaired neutrophil } \\
\text { chemotaxis }\end{array}$ & & \\
\hline 10 & MP:0008657 & $\begin{array}{l}\text { beta secretion } \\
\text { Abnormal intestinal }\end{array}$ & & \\
\hline 10 & MP:0000511 & mucosa morphology & & \\
\hline
\end{tabular}

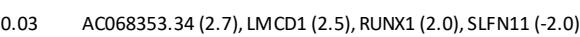

$0.03 \quad \operatorname{LINC00973(3.5),~RUNX1~(3.2),~LMCD1~(3.0),~BPNT1~(-2.1)~}$

$04 \operatorname{RASSF3}(2.5)$, LINC00299 (-2.0)

$0.001 \quad$ BPNT1 (2.0)

$0.002 \quad \operatorname{LINC01013(3.3)}$

$.005 \operatorname{PIEZO1}(2.5), \operatorname{AKR} 1 C 3(2.3)$

AKR1C3 (3.1), SLFN11 (2.4), RUNX1 (2.2), PBX1 (2.2), $\quad$ LINC01013 (2.1)

0.02 NA

RUNX1 (2.6), RAB3GAP2 (2.3), UBTD1 (2.1), HMG2OA (2.0)

$0.03 \quad \operatorname{SLFN11}(2.2)$, PEAK1 (2.0)

$0.03 \quad \operatorname{PIEZO1}(2.6), \operatorname{RP} 1 \mathrm{L1}(2.3)$

$0.04 \operatorname{SLFN11}(2.1)$

$0.04 \quad$ LINC00299 (2.2), TRIB1 (2.0)

$0.04 \quad \operatorname{LINC01013(2.6)}$

11 MP:0000761 Thin diaphragm muscle

$0.001 \quad \operatorname{LINC00973}(2.5)$, ABLIM2 (2.1)

11 MP:0004835 Abnormal miniature

0.01

ABLIM2 (4.7), UBTD1 (3.4), LINC00973 (2.4), TACR3 (2.4), PEAK1 (2.3), RUNX1 (2.2), CAND2 (2.0)

11 MP:0002826 Tonic seizures

0.01

11 ENSG00000125968 ID1 PPI subnetwork

11 MP:0001053 Abnormal neuromuscular

ENSG00000030304 MUSK PPI subnetwork $\quad$ synapse morphology $\quad$ muscle $\quad 0.02$

Abnormal neuromuscular Thin diaphragm $\quad 0.02$

$\begin{array}{llll}\text { ENSG00000030304 MUSK PPI subnetwork synapse morphology } & 0.02\end{array}$

0.02

$\operatorname{NRXN3}(3.2), \operatorname{LINCO0312}(2.2), \operatorname{SRR}(-2.0)$

ABLIM2 (2.2)

ABLIM2 (5.2), UBTD1 (3.6), PTPRM (3.0), TACR3 (2.6), NRXN3 (2.5),

RUNX1 (2.3)

11 MP:0000753 Paralysis 0.03

, RUNX1 (2.9), ABLIM2 (2.7), LMCD1 (2.2), TACR3 (2.1)

RAB3GAP2 (3.8), CBR1 (3.6), NRXN3 (2.7), SLC7A11 (2.4), CAND2 (2.2), SLFN11 (2.1), RASSF3 (-2.7)

11 ENSG00000174469 CNTNAP2 PPI subnetwork

0.03

NRXN3 (2.1)

11 GO:0031594 Neuromuscular junction $\quad 0.04$

11 MP:0002914 Abnormal endplate $\quad 0.04$

12 ENSG00000165702 GFI1B PPI subnetwork 0.04

$12 \quad$ GO:0051015 Actin filament binding

0.001

0.002

GO:0032432

Actin filament bundle

GO:0001725

Stress fiber

0.009

ABLIM2 (3.6), CAND2 (3.0), RUNX1 (2.4)

ABLIM2 (3.9), LINC01013 (3.4), RUNX1 (2.9), UBTD1 (2.9), LINC00973 (2.6), CAND2 (2.2)

SMG6 (2.2)

2 ENSG00000163466 ARPC2 PPI subnetwork

0.009

AC068353.34 (2.3), ANKRD20A11P (2.3), PIEZO1 (2.0)

LMCD1 (4.0), CAND2 (3.2), LINC00312 (2.9), PIEZO1 (2.6),

AC068353.34 (2.5), RASSF3 (2.1), SIPA1L1 (2.1)

LMCD1 (3.7), CAND2 (3.2), LINC00312 (2.9), AC068353.34 (2.3), RASSF3 (2.3), PIEZO1 (2.1), FHL5 (2.0)

$0.01 \quad \operatorname{AC068353.34~(2.7),~SMG6~(2.5),~PEAK1~(2.1),~SRR~(2.1)~}$

LMCD1 (3.6), CAND2 (3.2), LINC00312 (2.6), RASSF3 (2.5), SIPA1L1

(2.1), PIEZO1 (2.1), SMG6 (2.1), AC068353.34 (2.0)

RASSF3 (2.9), SIPA1L1 (2.1), CAND2 (2.0), LMCD1 (2.0), PBX1 (2.0) LINC00973 $(-2.5)$

$12 \quad$ ENSG00000135269

TES PPI subnetwork

$12 \quad$ ENSG00000145349

CAMK2D PPI subnetwork

Actomyosin

GFI1B PPI subnetwork

RAB3GAP2 (2.6), CAND2 (2.4), SIPA1L1 (2.2), RASSF3 (2.0)

REACTOME SMOOTH Reactome smooth muscle

contraction

0.03

HL5 (4.7), RASSF3 (3 UINC01648 (-2.1)

0.03

ENSG00000150867 PIP4K2A PPI subnetwork

SIPA1L1 (2.7), AC068353.34 (2.7), PEAK1 (2.3), ABLIM2 (2.2),

RAB3GAP2 (2.1), ERCC4 (2.1), CAND2 (2.0), SEZ6L (-2.1)

0.03

ENSG00000154556 SORBS2 PPI subnetwork

PEAK1 (2.2)

AC068353.34 (2.6), LMCD1 (2.6), PIEZO1 (2.6), RASSF3 (2.5), XPC (2.4), LINC00312 (2.0), LINC01648 (-3.0)

0.04

0.04

12 GO:0015629 Actin cytoskeleton

0.002

13 MP:0006354 $\begin{gathered}\text { Abnormal fourth branchial } \\ \text { arch artery morphology }\end{gathered}$

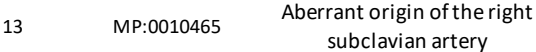

13 MP:0004157 Interrupted aortic arch

13 GO:0031490

13 GO:0048844

Chromatin DNA binding

Abnormal fourth

OXL1 (3.0), ERCC4 (2.6), PIEZO1 (2.3), TACR3 (2.2), RUNX1 (2.2)

FOXL1 (5.4), MN1 (3.2), LINCO0973 (2.7), RUNX1 (2.5), FHL5 (2.3),

UBTD1 (2.0), SEZ6L (2.0), IARS2 (-2.0) 


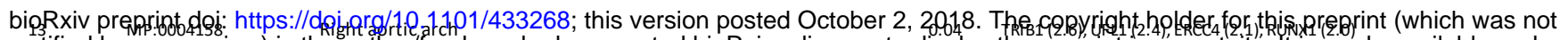
certified by peer review) is the author/funder, who has granted bioRxiv a license to display the preprint in perpetuity. It is made available under

\begin{tabular}{|c|c|c|c|c|c|c|}
\hline 14 & GO:0043073 & Germ cell nucleus & \multirow{2}{*}{$\begin{array}{l}\text { aCC-BY-NC-N } \\
\text { Germ cell nucleus }\end{array}$} & \multirow{2}{*}{$\begin{array}{l}4.0 \text { Internatıo } \\
\text { Germ cell nucleus }\end{array}$} & \multirow[b]{2}{*}{0.00313} & \multirow[b]{2}{*}{$\begin{array}{l}\operatorname{LINC01921~(4.9),~FHL5~(3.3),~SRR~(2.6),~LINC02064~(2.1),~LINC01013~} \\
(2.1)\end{array}$} \\
\hline 14 & GO:0001673 & Male germ cell nucleus & & & & \\
\hline 15 & MP:0009230 & $\begin{array}{l}\text { Abnormal sperm head } \\
\text { morphology }\end{array}$ & \multirow{8}{*}{ Teratozoospermia } & \multirow{8}{*}{$\begin{array}{l}\text { Abnormal sperm head } \\
\text { morphology }\end{array}$} & 0.00244 & LINC01921 (3.4), FHL5 (3.3), LINC00312 (2.6), HDGFL1 (2.4) \\
\hline 15 & MP:0009238 & Coiled sperm flagellum & & & 0.01 & LINC01921 (6.0), FHL5 (2.3), AL450226.1 (2.0) \\
\hline 15 & MP:0004542 & $\begin{array}{l}\text { Impaired acrosome } \\
\text { reaction }\end{array}$ & & & 0.01 & LINC01921 (3.8), FHL5 (3.7), UBTD1 (3.4), AC004944.1 (2.7) \\
\hline 15 & MP:0005578 & Teratozoospermia & & & 0.02 & LINC01921 (5.7), FHL5 (3.7), HDGFL1 (3.6), UBTD1 (2.0) \\
\hline 15 & MP:0000242 & Impaired fertilization & & & 0.03 & $\begin{array}{l}\text { LINC01921 (4.5), HDGFL1 (2.7), FHL5 (2.6), AC004944.1 (2.4), } \\
\text { 2.7) }\end{array}$ \\
\hline 15 & MP:0009232 & $\begin{array}{l}\text { Abnormal sperm nucleus } \\
\text { morphology }\end{array}$ & & & 0.03 & LINC01921 (5.6), FHL5 (2.7), HDGFL1 (2.0), AL450226.1 (2.0) \\
\hline 15 & GO:0007281 & Germ cell development & & & 0.04 & HDGFL1 (5.3), LINC01921 (5.2), FHL5 (2.7) \\
\hline 15 & MP:0010769 & Abnormal survival & & & 0.04 & TACR3 (2.4), RASSF3 (2.4) \\
\hline 16 & ENSG00000125503 & PPP1R12C PPI subnetwork & \multirow{11}{*}{ MYO1G PPI subnetwork } & \multirow{11}{*}{$\begin{array}{l}\text { PPP1R12C PPI } \\
\text { subnetwork }\end{array}$} & 0.003 & PIEZO1 (2.2), AC068353.34 (2.2), ANKRD20A11P (2.1) \\
\hline 16 & ENSG00000106992 & AK1 PPI subnetwork & & & 0.004 & RASSF3 (2.1) \\
\hline 16 & ENSG00000136286 & MYO1G PPI subnetwork & & & 0.005 & RASSF3 (2.2), ANKRD20A11P (2.0) \\
\hline 16 & ENSG00000013297 & CLDN11 PPI subnetwork & & & 0.005 & RASSF3 (2.4), ANKRD20A11P (2.4), PIEZO1 (2.0) \\
\hline 16 & ENSG00000166866 & MYO1A PPI subnetwork & & & 0.01 & $\begin{array}{l}\text { AC068353.34 (3.8), RASSF3 (2.7), LMCD1 (2.4), PEAK1 (2.3), } \\
\text { LINC01648 (-2.2) }\end{array}$ \\
\hline 16 & ENSG00000118260 & CREB1 PPI subnetwork & & & 0.02 & UBTD1 (3.2), SMG6 (2.2), LINC01921 (2.1) \\
\hline 16 & ENSG00000169220 & RGS14 PPI subnetwork & & & 0.02 & $\operatorname{RASSF} 3(2.7)$ \\
\hline 16 & ENSG00000136156 & ITM2B PPI subnetwork & & & 0.02 & RASSF3 (2.4), AC068353.34 (2.2), ANKRD20A11P (2.0) \\
\hline 16 & ENSG00000136068 & FLNB PPI subnetwork & & & 0.02 & $\begin{array}{l}\text { SRR (3.2), AC068353.34 (2.6), SMG6 (2.4), PIEZO1 (2.1), } \\
\text { (2.0), UBTD1 (2.0) }\end{array}$ \\
\hline 16 & ENSG00000105376 & ICAM5 PPI subnetwork & & & 0.03 & RASSF3 (2.1), ANKRD20A11P (2.0) \\
\hline 16 & ENSG00000139514 & SLC7A1 PPI subnetwork & & & 0.03 & $\operatorname{ANKRD20A11P}(2.3), \operatorname{RASSF} 3(2.2), \operatorname{GLIS1}(-2.0)$ \\
\hline 17 & GO:0043500 & Muscle adaptation & \multirow{16}{*}{ Muscle system process } & \multirow{16}{*}{ Muscle adaptation } & 0.003 & LINC00312 (3.9), RASSF3 (2.5), CAND2 (2.2), AL450226.1 (-2.5) \\
\hline 17 & GO:0090257 & $\begin{array}{l}\text { Regulation of muscle } \\
\text { system process }\end{array}$ & & & 0.01 & CAND2 (3.6), TACR3 (2.1) \\
\hline 17 & GO:0031143 & Pseudopodium & & & 0.01 & CAND2 (4.2), LMCD1 (3.7), ABLIM2 (2.1) \\
\hline 17 & GO:0003012 & Muscle system process & & & 0.02 & $\begin{array}{l}\text { CAND2 (4.7), ABLIM2 (2.7), RASSF3 (2.5), LMCD1 (2.1), } \\
\text { ANKRD20A11P (2.0) }\end{array}$ \\
\hline 17 & GO:0006937 & $\begin{array}{l}\text { Regulation of muscle } \\
\text { contraction }\end{array}$ & & & 0.03 & CAND2 (3.7) \\
\hline 17 & ENSG00000109846 & CRYAB PPI subnetwork & & & 0.03 & CAND2 (2.8), SLC7A11 (2.5), FHL5 (-2.6) \\
\hline 17 & ENSG00000135424 & ITGA7 PPI subnetwork & & & 0.03 & FHL5 (2.9), ABLIM2 (2.5), TACR3 (2.4), UBTD1 (2.4) \\
\hline 17 & GO:0055117 & $\begin{array}{l}\text { Regulation of cardiac } \\
\text { muscle contraction }\end{array}$ & & & 0.04 & LINC01013 (3.9), RASSF3 (2.1), AC004944.1 (2.0), LINC00312 (-2.4) \\
\hline 17 & GO:0048747 & Muscle fiber development & & & 0.04 & $\begin{array}{l}\text { AL450226.1 (3.2), CAND2 (3.2), ABLIM2 (3.0), RASSF3 (2.2), TACR3 } \\
(2.0) \text {, LINC01921 (2.0), SLFN11 (-2.4) }\end{array}$ \\
\hline 17 & ENSG00000177791 & MYOZ1 PPI subnetwork & & & 0.04 & CAND2 (3.8), LMCD1 (2.2) \\
\hline 17 & GO:0016460 & Myosin ii complex & & & 0.04 & CAND2 (4.2), LMCD1 (3.0) \\
\hline 17 & MP:0005140 & $\begin{array}{l}\text { Decreased cardiac muscle } \\
\text { contractility }\end{array}$ & & & 0.04 & $\operatorname{LMCD1}(3.4)$, CAND2 (3.2) \\
\hline 17 & GO:0000146 & $\begin{array}{l}\text { Microfilament motor } \\
\text { activity }\end{array}$ & & & 0.04 & CAND2 (2.8), LMCD1 (2.5) \\
\hline 17 & MP:0005620 & $\begin{array}{l}\text { Abnormal muscle } \\
\text { contractility }\end{array}$ & & & 0.04 & $\begin{array}{l}\text { FHL5 (3.0), CAND2 (3.0), NRXN3 (2.5), ABLIM2 (2.2), LINC00312 (2.1), } \\
\text { LMCD1 (2.0) }\end{array}$ \\
\hline 17 & GO:0006936 & Muscle contraction & & & 0.04 & CAND2 (4.8), ABLIM2 (2.7), RASSF3 (2.5), LMCD1 (2.0) \\
\hline 17 & GO:0005516 & Calmodulin binding & & & 0.04 & SIPA1L1 (3.1), ABLIM2 (3.1), LMCD1 (2.2), CAND2 (2.1) \\
\hline 18 & ENSG00000122641 & INHBA PPI subnetwork & \multirow{6}{*}{ INHBA PPI subnetwork } & \multirow{6}{*}{$\begin{array}{l}\text { INHBA PPI } \\
\text { subnetwork }\end{array}$} & 0.004 & RUNX1 (4.5), LMCD1 (4.0) \\
\hline 18 & ENSG00000106991 & ENG PPI subnetwork & & & 0.02 & $\operatorname{LMCD1}(4.2), \operatorname{RUNX1}(2.6), \operatorname{LINC01013~(2.1),~SRR~(-2.2)~}$ \\
\hline 18 & MP:0003645 & $\begin{array}{l}\text { Increased pancreatic beta } \\
\text { cell number }\end{array}$ & & & 0.03 & AC068353.34 (2.5), LINC00312 (2.0) \\
\hline 18 & ENSG00000175189 & INHBC PPI subnetwork & & & 0.03 & RUNX1 (5.3), LMCD1 (3.7), LINC00973 (2.6), MN1 (2.2) \\
\hline 18 & GO:0001558 & Regulation of cell growth & & & 0.04 & LMCD1 (3.0), ANKRD20A11P (2.7), AC004944.1 (2.4), GLIS1 (2.2) \\
\hline 18 & ENSG00000163083 & INHBB PPI subnetwork & & & 0.04 & RUNX1 (4.6), LMCD1 (2.8), MN1 (2.6) \\
\hline 19 & GO:0034504 & $\begin{array}{l}\text { Protein localization to } \\
\text { nucleus }\end{array}$ & \multirow{3}{*}{$\begin{array}{l}\text { Protein localization to } \\
\text { nucleus }\end{array}$} & \multirow{3}{*}{$\begin{array}{l}\text { Protein localization to } \\
\text { nucleus }\end{array}$} & 0.004 & $\operatorname{MN1}(2.9), X P C(2.0), \operatorname{PBX1}(2.0)$ \\
\hline 19 & GO:0006606 & $\begin{array}{l}\text { Protein import into } \\
\text { nucleus }\end{array}$ & & & 0.03 & MN1 (2.8), PBX1 (2.1), ANKRD20A11P (-2.0) \\
\hline 19 & GO:0051170 & Nuclear import & & & 0.04 & MN1 (2.8), PBX1 (2.0), RUNX1 (2.0) \\
\hline
\end{tabular}




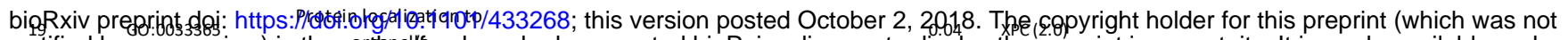
certified by peer review) is the artapollitunder, who has granted bioRxiv a license to display the preprint in perpetuity it is made available under

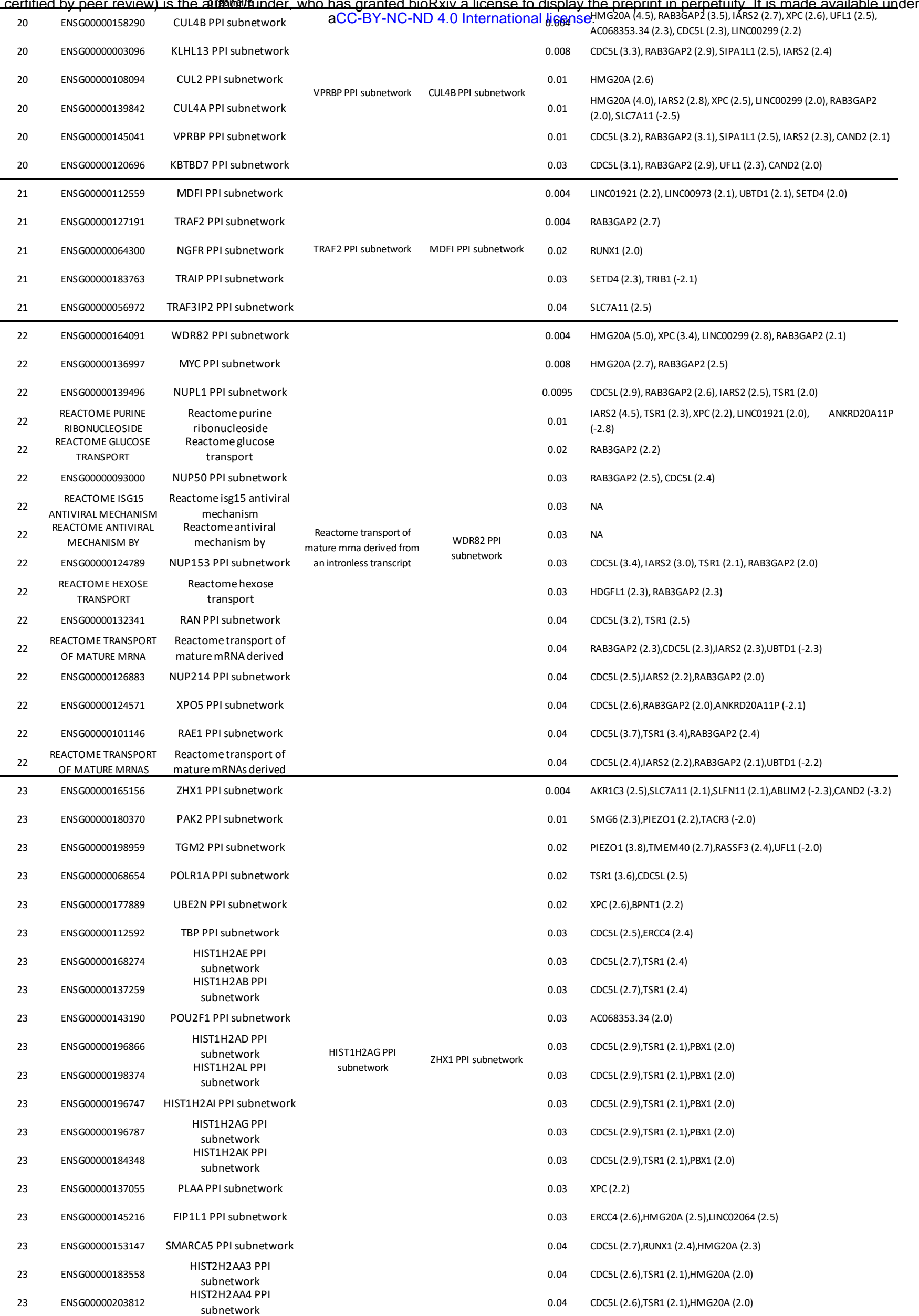




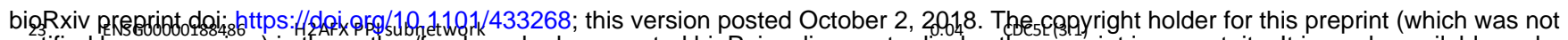
certified by peer review) is the authorffunder, who has granted bioRxiv a license to display the preprint in perpetuity. It is made available under

\begin{tabular}{|c|c|c|c|c|c|c|}
\hline 24 & GO:0045624 & $\begin{array}{l}\text { Positive regulation of t- } \\
\text { helper cell differentiation }\end{array}$ & \multirow{5}{*}{$\begin{array}{l}\text { Positive regulation of cd4- } \\
\text { positive, alpha-beta t cell } \\
\text { activation }\end{array}$} & \multirow{5}{*}{$\begin{array}{l}\text { Positive regulation of t- } \\
\text { helper cell } \\
\text { differentiation }\end{array}$} & \multirow[b]{2}{*}{0.007} & \multirow[t]{2}{*}{$e_{\text {RUNX1 (2.0) }}$} \\
\hline 24 & GO:2000516 & $\begin{array}{l}\text { Positive regulation of cd4- } \\
\text { positive, al pha-beta t cell }\end{array}$ & & & & \\
\hline 24 & GO:0043372 & $\begin{array}{l}\text { Positive regulation of cd4- } \\
\text { positive, al pha-beta t cell }\end{array}$ & & & 0.007 & NA \\
\hline 24 & GO:0046637 & $\begin{array}{l}\text { Regulation of alpha-beta } t \\
\text { cell differentiation }\end{array}$ & & & 0.04 & RUNX1 (2.2),LINC00299 (2.1) \\
\hline 24 & GO:0045086 & $\begin{array}{c}\text { Positive regulation of } \\
\text { interleukin-2 biosynthetic }\end{array}$ & & & 0.04 & AC004944.1 (3.7),ERCC4 (2.3) \\
\hline 25 & GO:0042744 & $\begin{array}{l}\text { Hydrogen peroxide } \\
\text { catabolic process }\end{array}$ & \multirow{5}{*}{ Reticulocytosis } & \multirow{5}{*}{$\begin{array}{l}\text { Hydrogen peroxide } \\
\text { catabolic process }\end{array}$} & 0.005 & $\begin{array}{l}\text { LINC01921 (3.5),LINC02064 (3.4),AKR1C3 (3.0),ANKRD20A11P } \\
\text { (2.3),BPNT1 (2.2) }\end{array}$ \\
\hline 25 & MP:0002640 & Reticulocytosis & & & 0.009 & AKR1C3 (2.7),BPNT1 (-2.3) \\
\hline 25 & GO:0015923 & Mannosidase activity & & & 0.01 & UFL1 (4.7),PIEZO1 (2.3) \\
\hline 25 & GO:0048872 & $\begin{array}{l}\text { Homeostasis of number of } \\
\text { cells }\end{array}$ & & & 0.03 & AKR1C3 (3.2),ERCC4 (2.9) \\
\hline 25 & MP:0001585 & Hemolytic anemia & & & 0.04 & AKR1C3 (3.1) \\
\hline 26 & ENSG00000088832 & FKBP1A PPI subnetwork & \multirow{13}{*}{ ARF6 PPI subnetwork } & \multirow{13}{*}{$\begin{array}{l}\text { FKBP1A PPI } \\
\text { subnetwork }\end{array}$} & 0.006 & SLC7A11 (2.6) \\
\hline 26 & ENSG00000165527 & ARF6 PPI subnetwork & & & 0.008 & IARS2 (3.9),SLC7A11 (2.8),HDGFL1 (2.8),UFL1 (2.5) \\
\hline 26 & ENSG00000184489 & PTP4A3 PPI subnetwork & & & 0.01 & $\begin{array}{l}\text { IARS2 (3.8),UFL1 (3.8),RAB3GAP2 (2.3),TSR1 (2.2),HDGFL1 } \\
\text { (2.2),BPNT1 (2.0) }\end{array}$ \\
\hline 26 & $\begin{array}{l}\text { REACTOME } \\
\text { ASSOCIATION OF }\end{array}$ & $\begin{array}{l}\text { Reactome association of } \\
\text { triccct with target proteins }\end{array}$ & & & 0.02 & IARS2 (2.8),HDGFL1 (2.5),UFL1 (2.4) \\
\hline 26 & ENSG00000198824 & CHAMP1 PPI subnetwork & & & 0.02 & UFL1 (2.8),TSR1 (2.5),RUNX1 (2.4),CDC5L (2.2),FOXL1 (-2.4) \\
\hline 26 & ENSG00000139637 & C12ORF10 PPI subnetwork & & & 0.02 & SLC7A11 (2.4),BPNT1 (2.4),FHL5 (-2.6) \\
\hline 26 & ENSG00000028137 & TNFRSF1B PPI subnetwork & & & 0.03 & IARS2 (2.9),SLC7A11 (2.4),UFL1 (2.3),TSR1 (2.1) \\
\hline 26 & ENSG00000180104 & EXOC3 PPI subnetwork & & & 0.03 & RAB3GAP2 (3.6),UFL1 (2.5),CDC5L (2.5),SEZ6L (2.0) \\
\hline 26 & ENSG00000129465 & RIPK3 PPI subnetwork & & & 0.03 & IARS2 (2.9) \\
\hline 26 & ENSG00000132432 & SEC61G PPI subnetwork & & & 0.03 & UFL1 (5.5) \\
\hline 26 & ENSG00000173530 & $\begin{array}{l}\text { TNFRSF10D PPI } \\
\text { subnetwork }\end{array}$ & & & 0.03 & IARS2 (3.3),XPC (2.5),SLC7A11 (2.5),TSR1 (2.2),CDC5L (2.1) \\
\hline 26 & ENSG00000141480 & ARRB2 PPI subnetwork & & & 0.04 & RASSF3 (2.3),SMG6 (2.3),UBTD1 (2.3),AC004944.1 (-2.1) \\
\hline 26 & ENSG00000068323 & TFE3 PPI subnetwork & & & 0.04 & IARS2 (3.7),SLC7A11 (2.8),CDC5L (2.0) \\
\hline 27 & GO:0045933 & $\begin{array}{l}\text { Positive regulation of } \\
\text { muscle contraction }\end{array}$ & \multirow{2}{*}{$\begin{array}{l}\text { Positive regulation of } \\
\text { smooth muscle contraction }\end{array}$} & \multirow{2}{*}{$\begin{array}{l}\text { Positive regulation of } \\
\text { muscle contraction }\end{array}$} & 0.007 & TACR3 (2.7),LINC01013 (2.6),LINC00312 (2.1),AC004944.1 (2.0) \\
\hline 27 & GO:0045987 & $\begin{array}{l}\text { Positive regulation of } \\
\text { smooth muscle }\end{array}$ & & & 0.03 & TACR3 (3.2),LINC00299 (3.0),LINC00312 (2.4),LINC01013 (2.0) \\
\hline 28 & ENSG00000078061 & ARAF PPI subnetwork & \multirow{17}{*}{ SHCBP1 PPI subnetwork } & \multirow{17}{*}{ ARAF PPI subnetwork } & 0.007 & CAND2 (2.4),SIPA1L1 (2.1),AL450226.1 (-2.3) \\
\hline 28 & ENSG00000120509 & PDZD11 PPI subnetwork & & & 0.008 & UBTD1 (2.0),AL450226.1 (-2.7) \\
\hline 28 & ENSG00000136153 & LMO7 PPI subnetwork & & & 0.01 & SIPA1L1 (2.9),TMEM40 (2.9),CAND2 (2.7),RASSF3 (2.6),GLIS1 (2.0) \\
\hline 28 & ENSG00000131941 & RHPN2 PPI subnetwork & & & 0.02 & AC068353.34 (3.0),TMEM40 (2.5),LINC01648 (2.1),PTPRM (2.0) \\
\hline 28 & ENSG00000161800 & RACGAP1 PPI subnetwork & & & 0.02 & AC068353.34 (3.4),LINC00312 (2.2) \\
\hline 28 & ENSG00000143375 & CGN PPI subnetwork & & & 0.02 & TMEM40 (2.3),AC068353.34 (2.3) \\
\hline 28 & ENSG00000171241 & SHCBP1 PPI subnetwork & & & 0.02 & AC068353.34 (2.8),TMEM40 (2.6) \\
\hline 28 & ENSG00000168476 & REEP4 PPI subnetwork & & & 0.03 & AC068353.34 (2.4),TMEM40 (2.4),LINC01648 (2.0),PTPRM (2.0) \\
\hline 28 & ENSG00000125731 & SH2D3A PPI subnetwork & & & 0.03 & $\operatorname{TMEM} 40(2.7), \operatorname{AC068353.34}(2.6), \operatorname{SETD} 4(-2.0)$ \\
\hline 28 & ENSG00000115963 & RND3 PPI subnetwork & & & 0.04 & TMEM40 (2.8),AC068353.34 (2.7),PTPRM (2.0),SRR (-2.7) \\
\hline 28 & ENSG00000189319 & FAM53B PPI subnetwork & & & 0.04 & TMEM40 (2.5),AC068353.34 (2.5) \\
\hline 28 & ENSG00000163362 & C1ORF106 PPI subnetwork & & & 0.04 & TMEM40 (2.5),AC068353.34 (2.3),PTPRM (2.0) \\
\hline 28 & ENSG00000138771 & SHROOM3 PPI subnetwork & & & 0.04 & AC068353.34 (2.5),TMEM40 (2.5),LINC01648 (2.0),SETD4 (-2.0) \\
\hline 28 & ENSG00000197555 & SIPA1L1 PPI subnetwork & & & 0.04 & AC068353.34 (2.5),TMEM40 (2.4),LINC01648 (2.0) \\
\hline 28 & GO:0030216 & $\begin{array}{l}\text { Keratinocyte } \\
\text { differentiation }\end{array}$ & & & 0.04 & TMEM40 (4.9) \\
\hline 28 & ENSG00000075413 & MARK3 PPI subnetwork & & & 0.04 & FHL5 (3.1),AC068353.34 (2.2) \\
\hline 28 & ENSG00000171219 & $\begin{array}{l}\text { CDC42BPG PPI } \\
\text { subnetwork }\end{array}$ & & & 0.04 & AC068353.34 (2.8),TMEM40 (2.3),LINC01648 (2.3) \\
\hline 29 & GO:0017119 & Golgi transport complex & \multirow{4}{*}{ Golgi transport complex } & \multirow{4}{*}{$\begin{array}{l}\text { Golgi transport } \\
\text { complex }\end{array}$} & 0.008 & UFL1 (4.4),RAB3GAP2 (4.2),IARS2 (2.8),BPNT1 (2.3) \\
\hline 29 & ENSG00000135775 & COG2 PPI subnetwork & & & 0.02 & RAB3GAP2 (2.2), LINC01013 (2.1),XPC (2.0) \\
\hline 29 & ENSG00000164597 & COG5 PPI subnetwork & & & 0.02 & RAB3GAP2 (2.6) \\
\hline 29 & GO:0007030 & Golgi organization & & & 0.04 & UFL1 (4.7),RAB3G \\
\hline
\end{tabular}




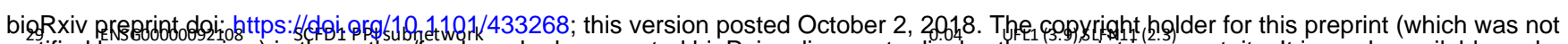
certified by peer review) is the author/funder, who has granted bioRxiv a license to display the preprint in perpetuity. It is made available under

\begin{tabular}{|c|c|c|c|c|c|c|}
\hline 30 & ENSG00000184575 & XPOT PPI subnetwork & \multirow{3}{*}{ SPTLC1 PPI subnetwork } & \multirow{3}{*}{ XPOT PPI subnetwork } & 0.008 & CDC5L (2.8),PTPRM (2.0) \\
\hline 30 & ENSG00000090054 & SPTLC1 PPI subnetwork & & & 0.03 & IARS2 (3.0),CDC5L (2.7),TSR1 (2.4) \\
\hline 30 & ENSG00000137767 & SQRDL PPI subnetwork & & & 0.04 & PIEZO1 (2.6),UFL1 (2.0) \\
\hline 31 & MP:0001147 & Small testis & \multirow{3}{*}{ Azoospermia } & \multirow{3}{*}{ Small testis } & 0.008 & HDGFL1 (5.1),LINC01921 (2.6),ANKRD20A11P (2.3) \\
\hline 31 & MP:0008261 & Arrest of male meiosis & & & 0.04 & HDGFL1 (5.0) \\
\hline 31 & MP:0005159 & Azoospermia & & & 0.04 & HDGFL1 (5.9),LINC01921 (2.0) \\
\hline 32 & ENSG00000082781 & ITGB5 PPI subnetwork & \multirow{5}{*}{ ITGB6 PPI subnetwork } & \multirow{5}{*}{ ITGB5 PPI subnetwork } & 0.009 & $\begin{array}{l}\text { PIEZO1 (2.9),LMCD1 (2.9),LINC00973 (2.6),UBTD1 (2.3),PEAK1 } \\
(2.1), \text { PTPRM (2.0),LINC01648 (-2.4),BPNT1 (-2.6) }\end{array}$ \\
\hline 32 & ENSG00000115221 & ITGB6 PPI subnetwork & & & 0.01 & PIEZO1 (2.9),LINC01648 (-2.1) \\
\hline 32 & ENSG00000105855 & ITGB8 PPI subnetwork & & & 0.02 & PIEZO1 (2.8),FOXL1 (2.3) \\
\hline 32 & GO:0008305 & Integrin complex & & & 0.04 & TMEM40 (3.4),PIEZO1 (2.8),RASSF3 (2.0),LINC01013 (-2.7) \\
\hline 32 & MP:0000069 & Kyphoscoliosis & & & 0.04 & PIEZO1 (2.6),PTPRM (2.0) \\
\hline 33 & GO:0050708 & $\begin{array}{l}\text { Regulation of protein } \\
\text { secretion }\end{array}$ & \multirow{5}{*}{$\begin{array}{l}\text { Regulation of protein } \\
\text { secretion }\end{array}$} & \multirow{5}{*}{$\begin{array}{l}\text { Regulation of protein } \\
\text { secretion }\end{array}$} & 0.009 & NA \\
\hline 33 & GO:0050707 & $\begin{array}{l}\text { Regulation of cytokine } \\
\text { secretion }\end{array}$ & & & 0.02 & LINC00299 (3.8),LINC01013 (2.8),SLFN11 (2.3) \\
\hline 33 & GO:0051048 & $\begin{array}{l}\text { Negative regulation of } \\
\text { secretion }\end{array}$ & & & 0.04 & LINC01648 (2.7),SEZ6L (2.1),HMG2OA (-2.3) \\
\hline 33 & GO:0009306 & Protein secretion & & & 0.04 & NA \\
\hline 33 & GO:0070201 & $\begin{array}{c}\text { Regulation of } \\
\text { establishment of protein }\end{array}$ & & & 0.04 & NA \\
\hline 34 & ENSG00000197905 & TEAD4 PPI subnetwork & \multirow{5}{*}{$\begin{array}{l}\text { Abnormal eye anterior } \\
\text { chamber morphology }\end{array}$} & \multirow{5}{*}{$\begin{array}{l}\text { TEAD4 PPI } \\
\text { subnetwork }\end{array}$} & 0.01 & $\begin{array}{l}\text { FOXL1 (3.2),SLFN11 (2.9),PTPRM (2.2),GLIS1 (2.1),UBTD1 } \\
(2.0), \operatorname{TMEM} 40(2.0), A B L I M 2(-2.0), A N K R D 20 A 11 \text { P (-2.2) }\end{array}$ \\
\hline 34 & MP:0005205 & $\begin{array}{l}\text { Abnormal eye anterior } \\
\text { chamber morphology }\end{array}$ & & & 0.01 & MN1 (3.4),LINC00973 (3.0),LMCD1 (2.1),LINC02064 (2.0) \\
\hline 34 & MP:0001322 & Abnormal iris morphology & & & 0.02 & NA \\
\hline 34 & MP:0005542 & Corneal vascularization & & & 0.02 & FASLG (2.3),HMG2OA (-2.1) \\
\hline 34 & MP:0004624 & $\begin{array}{c}\text { Abnormal thoracic cage } \\
\text { morphology }\end{array}$ & & & 0.03 & MN1 (2.3),PBX1 (2.2) \\
\hline 35 & MP:0004876 & $\begin{array}{l}\text { Decreased mean systemic } \\
\text { arterial blood pressure }\end{array}$ & \multirow{6}{*}{ Regulation of tube size } & \multirow{6}{*}{$\begin{array}{c}\text { Decreased mean } \\
\text { systemic arterial blood } \\
\text { pressure }\end{array}$} & 0.01 & FHL5 (3.8),FOXL1 (2.8),PTPRM (2.4),TACR3 (2.3),LINC00299 (2.3) \\
\hline 35 & MP:0008874 & $\begin{array}{l}\text { Decreased physiological } \\
\text { sensitivity to xenobiotic }\end{array}$ & & & 0.02 & $\operatorname{SLC7A11~(3.2),FOXL1~(2.6),ABLIM2~(2.0)~}$ \\
\hline 35 & GO:0035150 & Regulation of tube size & & & 0.03 & FHL5 (3.5),FOXL1 (3.0) \\
\hline 35 & GO:0050880 & $\begin{array}{l}\text { Regulation of blood vessel } \\
\text { size }\end{array}$ & & & 0.03 & FHL5 (3.6),FOXL1 (3.0) \\
\hline 35 & GO:0042310 & Vasoconstriction & & & 0.03 & FHL5 (4.0),FOXL1 (3.2) \\
\hline 35 & MP:0001613 & Abnormal vasodilation & & & 0.04 & FHL5 (2.7),PIEZO1 (2.2),PTPRM (2.1),CBR1 (2.0),HMG20A (-2.0) \\
\hline 36 & ENSG00000166930 & MS4A5 PPI subnetwork & \multirow{4}{*}{ MS4A5 PPI subnetwork } & \multirow{4}{*}{$\begin{array}{l}\text { MS4A5 PPI } \\
\text { subnetwork }\end{array}$} & 0.01 & NA \\
\hline 36 & ENSG00000173702 & MUC13 PPI subnetwork & & & 0.01 & NA \\
\hline 36 & ENSG00000169306 & IL1RAPL1 PPI subnetwork & & & 0.01 & ANKRD20A11P (2.3) \\
\hline 36 & ENSG00000198478 & SH3BGRL2 PPI subnetwork & & & 0.03 & NA \\
\hline
\end{tabular}


Supplementary Table 4. Enrichment of tissue and cell types from DEPICT. Suggestive enrichment (FDR $<0.20)$ was observed for 21 categories of tissues and/or cell types. Two categories where

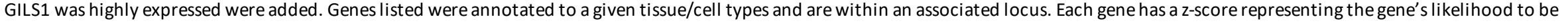

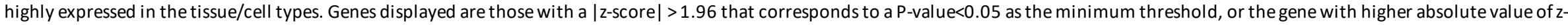
score $\left.{ }^{*}\right)$. MeSH: Medical Subject Headings, FDR: false discovery rate.

\begin{tabular}{|c|c|c|c|c|c|c|}
\hline MeSH term & Name & MeSH first level term & MeSH second level term & P value & FDR & Contributing genes \\
\hline A15.145.846 & Serum & Hemic and Immune Systems & Blood & $2.61 \mathrm{E}-03$ & $<0.20$ & LINC01013 (2.9),UBTD1 (2.6),ERCC4 (2.0),UFL1 (-2.1) \\
\hline A10.690.467 & Muscle Smooth & Tissues & Muscles & $3.94 \mathrm{E}-03$ & $<0.20$ & FOXL1 (3.2) \\
\hline A07.231 & Blood Vessels & Cardiovascular System & Blood Vessels & $4.25 \mathrm{E}-03$ & $<0.20$ & LINC01013 (4.1),UBTD1 (2.3) \\
\hline A11.620.520 & Myocytes Smooth Muscle & Cells & Muscle Cells & $5.36 \mathrm{E}-03$ & $<0.20$ & FOXL1 (4.8),TACR3 (2.6),LINC00973 (2.4),LINC01648 (2.1),SRR (2.0) \\
\hline A11.620 & Muscle Cells & Cells & Muscle Cells & $5.36 \mathrm{E}-03$ & $<0.20$ & FOXL1 (4.8),TACR3 (2.6),LINC00973 (2.4),LINC01648 (2.1),SRR (2.0) \\
\hline A11.872.190.260 & Embryoid Bodies & Cells & Stem Cells & $5.92 \mathrm{E}-03$ & $<0.20$ & TACR3 (2.6) \\
\hline A11.329.228 & Fibroblasts & Cells & Connective Tissue Cells & $6.72 \mathrm{E}-03$ & $<0.20$ & FOXL1 (2.2),SRR (2.1) \\
\hline A11.329 & Connective Tissue Cells & Cells & Connective Tissue Cells & $8.20 \mathrm{E}-03$ & $<0.20$ & *SLC7A11 (1.3) \\
\hline A07.231.908 & Veins & Cardiovascular System & Blood Vessels & $9.70 \mathrm{E}-03$ & $<0.20$ & LINC01013 (5.8),UBTD1 (2.6),SLC7A11 (2.0) \\
\hline A10.165.450.300.425 & Keloid & Tissues & Connective Tissue & $1.00 \mathrm{E}-02$ & $<0.20$ & $\begin{array}{l}\text { MN1 (3.4),PEAK1 (3.1),XPC (2.7),HDGFL1 (2.5),LINC02064 (2.3),GLIS1 } \\
\text { (2.3).LINC01648 (2.3).SLC7A11 (2.0).TRIB1 (-2.5) }\end{array}$ \\
\hline A05.360.444.492 & Penis & Urogenital System & Genitalia & $1.00 \mathrm{E}-02$ & $<0.20$ & *LINC01921 (1.9) \\
\hline A05.360.444.492.362 & Foreskin & Urogenital System & Genitalia & $1.00 \mathrm{E}-02$ & $<0.20$ & LINC01921 (2.0) \\
\hline A07.231.908.670.874 & Umbilical Veins & Cardiovascular System & Blood Vessels & $1.00 \mathrm{E}-02$ & $<0.20$ & LINC01013 (6.3),UBTD1 (2.8),SLC7A11 (2.2) \\
\hline A07.231.908.670 & Portal System & Cardiovascular System & Blood Vessels & $1.00 \mathrm{E}-02$ & $<0.20$ & LINC01013 (6.3),UBTD1 (2.8),SLC7A11 (2.2) \\
\hline A10.165.450.300 & Cicatrix & Tissues & Connective Tissue & $1.00 \mathrm{E}-02$ & $<0.20$ & $\begin{array}{l}\text { MN1 (3.1),PEAK1 (2.9),HDGFL1 (2.4),XPC (2.3),LINC02064 (2.2),LINC01648 } \\
\text { (2.0).TRIB1 (-2.3) }\end{array}$ \\
\hline A10.165.450 & Granulation Tissue & Tissues & Connective Tissue & $1.00 \mathrm{E}-02$ & $<0.20$ & $\begin{array}{l}\text { MN1 (3.1),PEAK1 (2.9),HDGFL1 (2.4),XPC (2.3),LINC02064 (2.2),LINC01648 } \\
\text { (2.0).TRIB1 (-2.3) }\end{array}$ \\
\hline A11.436.275 & Endothelial Cells & Cells & Epithelial Cells & $1.00 \mathrm{E}-02$ & $<0.20$ & LINC01013 (3.8),UBTD1 (2.4) \\
\hline A10.690 & Muscles & Tissues & Muscles & $2.00 \mathrm{E}-02$ & $<0.20$ & $\begin{array}{l}\text { LINC00312 (3.3),MN1 (2.7),CAND2 (2.4),LMCD1 (2.4),ABLIM2 (2.4),LINC02064 } \\
\text { (2.3) }\end{array}$ \\
\hline A07.231.114 & Arteries & Cardiovascular System & Blood Vessels & $2.00 \mathrm{E}-02$ & $<0.20$ & FOXL1 (2.7),FHL5 (2.4),LINC01013 (2.0) \\
\hline A11.329.629 & Osteoblasts & Cells & Connective Tissue Cells & $2.00 \mathrm{E}-02$ & $<0.20$ & $\begin{array}{l}\text { LINC01013 (4.1),ERCC4 (2.9),GLIS1 (2.8),PEAK1 (2.7),SLC7A11 (2.5),LMCD1 } \\
\text { (2.3).SIPA1L1 (2.1).PTPRM (2.1).SRR (2.0) }\end{array}$ \\
\hline A11.872.580 & Mesenchymal Stem Cells & Cells & Stem Cells & $3.00 \mathrm{E}-02$ & $<0.20$ & SRR (2.3),GLIS1 (2.3),PEAK1 (2.2) \\
\hline A07.541.510.110 & Aortic Valve & Cardiovascular System & Heart & $1.30 \mathrm{E}-01$ & $>=0.20$ & GLIS1 (6.2),LINC00312 (2.2),PTPRM (1.9) \\
\hline A07.541.510 & Heart Valves & Cardiovascular System & Heart & $1.30 \mathrm{E}-01$ & $>=0.20$ & GLIS1 (6.2),LINC00312 (2.2),PTPRM (1.9) \\
\hline
\end{tabular}


Supplementary Table 5 . The 6 enriched gene sets (FDR $<0.05$ ) where GLIS1 was found to be the best-ranked gene by i-GSEA4GWAS. Enrichment significance ( $p$-value and FDR) of pathways / gene sets are displayed. Genes where SNPs are associated with MVP (P-value < 0.01 from the GWAS metaanalysis) are listed from the most to the less significant.

\begin{tabular}{|c|c|c|c|}
\hline Gene Set Name & P-value & FDR & Significant genes in the pathway/gene set \\
\hline GO: Positive Regulation of Transcription DNA Dependent & 0.001 & 0.001 & $\begin{array}{l}\text { GLIS1; RUNX1; SMAD3; MKL2; SQSTM1; NUFIP1; NRIP1; PAX8; GLIS3; TBX5; CREB5; } \\
\text { ESRRG; MDFIC; RXRA; MYO6; ARNTL }\end{array}$ \\
\hline GO: Positive Regulation of RNA Metabolic Process & 0.001 & 0.002 & $\begin{array}{l}\text { GLIS1; RUNX1; SMAD3; MKL2; SQSTM1; NUFIP1; NRIP1; PAX8; GLIS3; TBX5; CREB5; } \\
\text { ESRRG; MDFIC; RXRA; MYO6; ARNTL }\end{array}$ \\
\hline GO: Positive Regulation of Transcription & 0.001 & 0.003 & $\begin{array}{l}\text { GLIS1; RUNX1; SMAD3; HIVEP3; MKL2; IRF4; SQSTM1; NUFIP1; NRIP1; PAX8; GLIS3; } \\
\text { TBX5; CREB5; ESRRG; MDFIC; RXRA; NFATC2; MYO6; ARNTL; GLIS2 }\end{array}$ \\
\hline $\begin{array}{l}\text { GO: Positive Regulation of Nucleobasenucleosidenucleotide and } \\
\text { Nucleic Acid Metabolic Process }\end{array}$ & 0.001 & 0.004 & $\begin{array}{l}\text { GLIS1; RUNX1; SMAD3; HIVEP3; MKL2; IRF4; SQSTM1; NUFIP1; NRIP1; PAX8; GLIS3; } \\
\text { TBX5; CREB5; ESRRG; MDFIC; ABCA1; RXRA; NFATC2; MYO6; ARNTL; GLIS2 }\end{array}$ \\
\hline $\begin{array}{l}\text { GO: Positive Regulation of Transcription From RNA Polymerase li } \\
\text { Promoter }\end{array}$ & 0.001 & 0.009 & GLIS1; RUNX1; SMAD3; MKL2; SQSTM1; NUFIP1; NRIP1; GLIS3; RXRA; MYO6; ARNTL \\
\hline GO: Negative Regulation of Transcription & 0.002 & 0.011 & $\begin{array}{l}\text { GLIS1; SMAD3; NFX1; MECP2; NRIP1; TGIF1; GLIS3; BCOR; VDR; TIMELESS; RFX3; } \\
\text { ARHGAP35; SUDS3; GLIS2 }\end{array}$ \\
\hline GO: Negative Regulation of RNA Metabolic Process & 0.023 & 0.089 & GLIS1; SMAD3; NFX1; MECP2; NRIP1; TGIF1; GLIS3; BCOR \\
\hline GO: Specific RNA Polymerase li Transcription Factor Activity & 0.044 & 0.119 & GLIS1; GLIS3; SOX9; RXRA \\
\hline
\end{tabular}




\begin{tabular}{|c|c|c|c|c|c|c|}
\hline \multicolumn{7}{|c|}{ 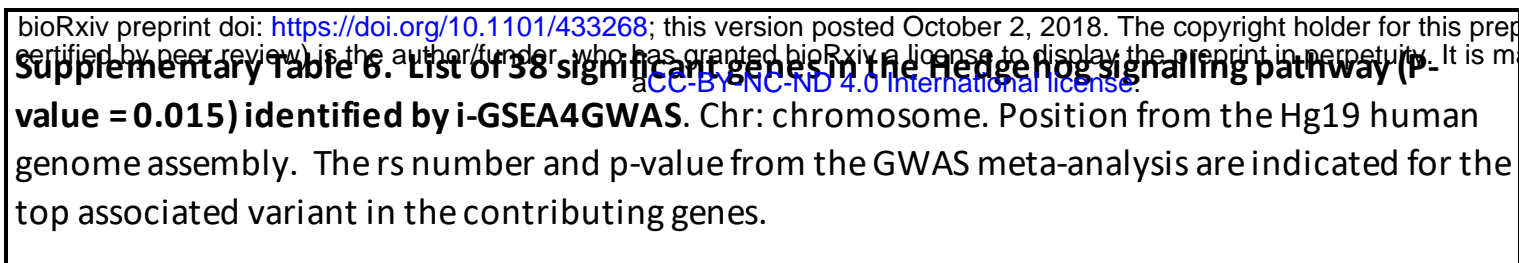 } \\
\hline Gene Name & Chr & Gene Start & Gene End & $\begin{array}{l}\text { Variant } \\
\text { Position }\end{array}$ & $\begin{array}{c}\text { Associated } \\
\text { variant }\end{array}$ & $\begin{array}{l}\text { Association P- } \\
\text { value in GWAS }\end{array}$ \\
\hline WNT5B & 12 & 1639057 & 1756409 & 1749905 & rs2270038 & 2.07E-03 \\
\hline WNT9B & 17 & 44910567 & 44964096 & 44929325 & rs56344308 & $2.43 \mathrm{E}-03$ \\
\hline BMP6 & 6 & 7727030 & 7881655 & 7759886 & rs270402 & $2.78 \mathrm{E}-03$ \\
\hline WNT4 & 1 & 22446461 & 22470462 & 22495261 & rs2807352 & 2.79E-03 \\
\hline HHIP & 4 & 145567173 & 145666423 & 145668076 & rs7699504 & $3.18 \mathrm{E}-03$ \\
\hline WNT11 & 11 & 75897369 & 75921780 & 75882890 & rs60995418 & $3.58 \mathrm{E}-03$ \\
\hline WNT7B & 22 & 46316242 & 46373009 & 46279265 & rs28371399 & 4.03E-03 \\
\hline BMP5 & 6 & 55618443 & 55740362 & 55601702 & rs2093373 & $4.22 \mathrm{E}-03$ \\
\hline WNT8A & 5 & 137419581 & 137428054 & 137405781 & rs7721939 & 4.49E-03 \\
\hline CSNK1E & 22 & 38686697 & 38794527 & 38741793 & rs5750597 & 4.75E-03 \\
\hline WNT16 & 7 & 120965421 & 120981158 & 120963965 & rs3757552 & $5.08 \mathrm{E}-03$ \\
\hline PTCH1 & 9 & 98205262 & 98279339 & 98336854 & rs111896098 & $5.22 \mathrm{E}-03$ \\
\hline CSNK1G2 & 19 & 1941188 & 1981337 & 1941121 & rs112624009 & $6.95 \mathrm{E}-03$ \\
\hline RAB23 & 6 & 57053607 & 57087078 & 57117624 & rs2064245 & 7.47E-03 \\
\hline GSK3B & 3 & 119540170 & 119813264 & 119598409 & rs62264713 & $8.19 \mathrm{E}-03$ \\
\hline SUFU & 10 & 104263744 & 104393292 & 104397323 & rs186502091 & $8.40 \mathrm{E}-03$ \\
\hline GLI2 & 2 & 121493199 & 121750229 & 121567079 & rs55922034 & 8.59E-03 \\
\hline WNT5A & 3 & 55499743 & 55523973 & 55450917 & rs35262007 & $9.14 \mathrm{E}-03$ \\
\hline WNT7A & 3 & 13857755 & 13921618 & 13892543 & rs17038710 & 1.07E-02 \\
\hline PRKACB & 1 & 84543745 & 84704181 & 84513318 & rs76776503 & $1.10 \mathrm{E}-02$ \\
\hline WNT9A & 1 & 228106357 & 228135631 & 228084158 & rs883583 & $1.12 \mathrm{E}-02$ \\
\hline $\mathrm{SHH}$ & 7 & 155592680 & 155604967 & 155642784 & rs74319244 & $1.29 \mathrm{E}-02$ \\
\hline LRP2 & 2 & 169983619 & 170219195 & 170184814 & rs9710881 & $1.31 \mathrm{E}-02$ \\
\hline PRKX & $x$ & 3522411 & 3631649 & 3609554 & rs56390349 & $1.39 \mathrm{E}-02$ \\
\hline GAS1 & 9 & 89559279 & 89562104 & 89575055 & rs1927083 & $1.52 \mathrm{E}-02$ \\
\hline BMP2 & 20 & 6748311 & 6760927 & 6676723 & rs6054474 & $1.53 \mathrm{E}-02$ \\
\hline BTRC & 10 & 103113820 & 103317078 & 103126789 & rs11593144 & $1.55 \mathrm{E}-02$ \\
\hline WNT3A & 1 & 228194752 & 228248961 & 228226602 & rs76082193 & $1.56 \mathrm{E}-02$ \\
\hline BMP7 & 20 & 55743804 & 55841685 & 55765481 & rs138980309 & 1.57E-02 \\
\hline
\end{tabular}




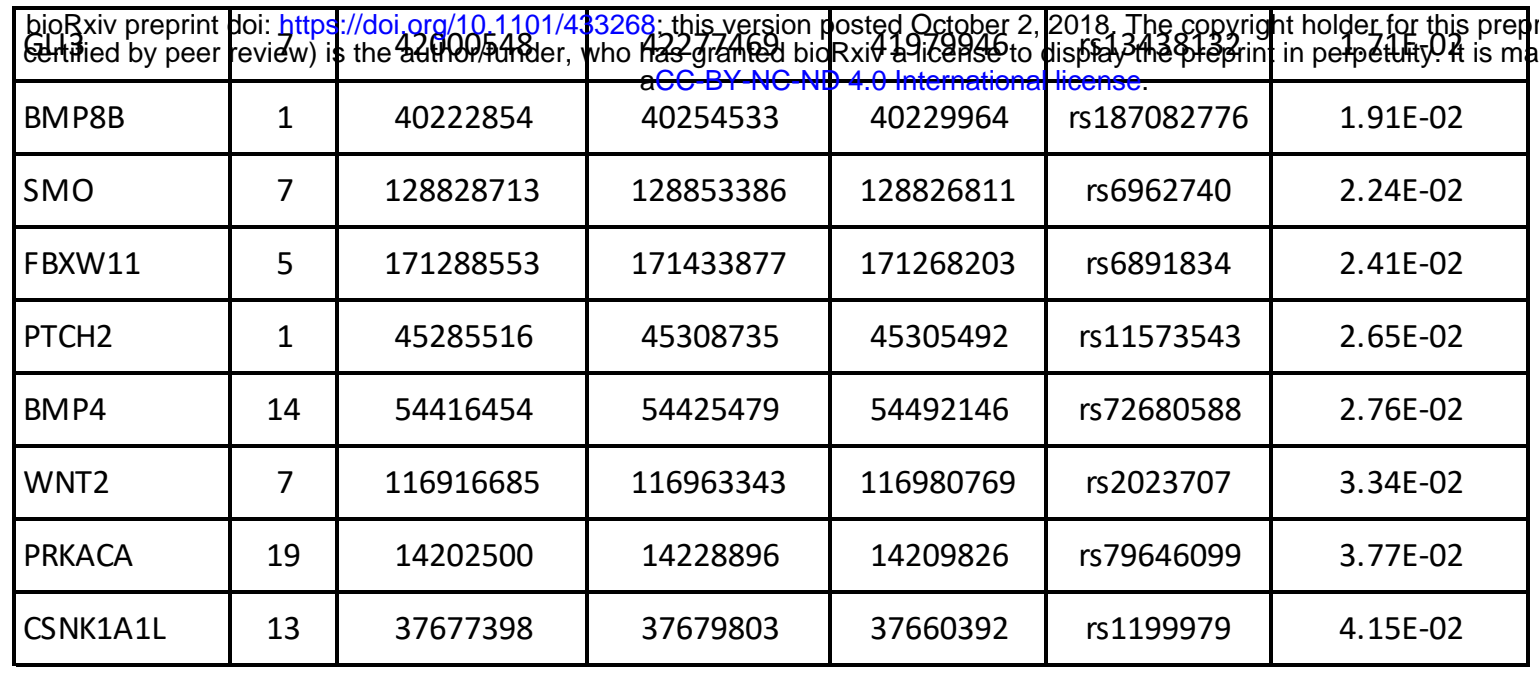


bioRxiv preprint doi: https://doi.org/10.1101/433268; this version posted October 2, 2018. The copyright holder for this preprint (which was not

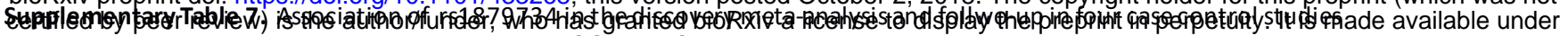
aCC-BY-NC-ND 4.0 International license.

\begin{tabular}{|c|c|c|c|c|}
\hline & MVP Cases & Controls & OR $[95 \% \mathrm{Cl}]$ & P-value \\
\hline MVP-Nantes & 489 & 873 & $1.44[1.18-1.76]$ & $3.20 \times 10^{-4}$ \\
\hline MVP-France & 953 & 1566 & $1.23[1.07-1.41]$ & $3.32 \times 10^{-3}$ \\
\hline Discovery meta-analysis & & & & $6.80 \times 10^{-6}$ \\
\hline $\mathrm{MGH} / \mathrm{FHS}$ & 699 & 5575 & $1.21[1.05-1.40]$ & $1.40 \times 10^{-4}$ \\
\hline HEGP-Surgery & 450 & 820 & $1.22[1.01-1.48]$ & 0.037 \\
\hline PROMESA & 171 & 282 & $1.06[0.77-1.46]$ & 0.88 \\
\hline IUPCQ & 102 & 102 & $0.89[0.56-1.44]$ & 0.64 \\
\hline Global meta-analysis & 2864 & 9218 & $1.23[1.14-1.33]$ & $1.29 \times 10^{-7}$ \\
\hline Heterogeneity & & & & 0.41 \\
\hline
\end{tabular}

\footnotetext{
* N: Numbers; OR: odds ratio; $95 \% \mathrm{Cl}$ : 95\% confidence interval

+ Alleles are indexed to the forward strand of NCBI Build 37

‡ P-values reported are two-sided and based on an inverse-variance weighted meta-analysis model (fixed effects)

$\S$ The P-value for heterogeneity corresponds to Cochran's Q statistic.
} 


\begin{tabular}{|c|c|c|c|c|c|c|c|c|c|}
\hline SNP & $\begin{array}{l}\text { Position } \\
\text { (bp on Chr1) }\end{array}$ & $\begin{array}{c}\text { DNASEV in } \\
\text { cell types }\end{array}$ & $\begin{array}{l}\text { Cell types name } \\
\text { for DNASEV }\end{array}$ & $\begin{array}{l}\text { Detail of cell types for } \\
\text { DNASEV }\end{array}$ & $\begin{array}{c}\text { Karyotype of } \\
\text { DNASEV }\end{array}$ & TFBS & $\begin{array}{c}\text { LD with } \\
\text { rs1879734 }\left(r^{2}\right)\end{array}$ & $\begin{array}{l}\text { eQTLP- } \\
\text { value }\end{array}$ & $\begin{array}{c}\text { MVP GWAS } \\
\text { P-value }\end{array}$ \\
\hline rs28743002 & 54125615 & 1 & Epithelium & $\begin{array}{c}\text { Epithelium cell from a } \\
\text { lung carcinoma }\end{array}$ & Cancer & & 0.69 & - & $7.85 \mathrm{E}-05$ \\
\hline rs17383325 & 54126552 & 2 & Skin & Fetal buttock fibroblast & Normal & & 0.73 & - & $6.50 \mathrm{E}-05$ \\
\hline rs12026298 & 54126754 & & & & & & 0.73 & - & 7.47E-05 \\
\hline rs11206187 & 54127969 & 3 & Lung & Fetal lung fibroblast & Normal & CTCF & 0.73 & - & $5.24 \mathrm{E}-05$ \\
\hline rs 2950241 & 54129591 & 20 & Blood & Lymphoblastoid & Normal & NR3C1 & 0.95 & 0.009 & $1.79 \mathrm{E}-05$ \\
\hline rs12405835 & 54129732 & & & & & & 0.73 & 0.039 & 4.65E-05 \\
\hline rs3006905 & 54130119 & & & & & & 0.95 & 0.033 & $1.38 \mathrm{E}-05$ \\
\hline rs4927025 & 54131753 & 4 & Skin & Toe fibroblast & Normal & & 0.77 & 0.024 & $2.72 \mathrm{E}-05$ \\
\hline rs6658469 & 54133345 & & & & & & 0.77 & 0.046 & $3.00 \mathrm{E}-05$ \\
\hline rs67319173 & 54133723 & & & & & & 0.77 & 0.024 & $2.69 \mathrm{E}-05$ \\
\hline rs1465037 & 54135078 & & & & & & 0.77 & 0.025 & 2.67E-05 \\
\hline rs1554750 & 54135334 & 30 & Brain & Gliblastoma & Cancer & TCF7L2, BHLHE40, USF1 & 0.77 & 0.024 & $2.66 \mathrm{E}-05$ \\
\hline rs2141080 & 54138489 & & & & & & 1.00 & - & $6.83 \mathrm{E}-06$ \\
\hline rs2141081 & 54138552 & 1 & Epithelium & $\begin{array}{l}\text { Epithelium cell from a } \\
\text { lung carcinoma }\end{array}$ & Cancer & & 0.91 & - & $6.84 \mathrm{E}-06$ \\
\hline rs2141082 & 54138698 & & & & & & 1.00 & - & 8.79E-06 \\
\hline rs1879734 & 54138854 & & & & & GATA2 & 1.00 & 0.048 & $6.80 \mathrm{E}-06$ \\
\hline rs4927026 & 54140843 & 2 & Skin & Fetal buttock fibroblast & Normal & & 0.73 & - & $5.35 \mathrm{E}-05$ \\
\hline rs4927027 & 54141274 & 3 & Lung & Fetal lung fibroblast & Normal & & 1.00 & - & $9.52 \mathrm{E}-06$ \\
\hline rs7543166 & 54143423 & & & & & & 1.00 & - & $1.24 \mathrm{E}-05$ \\
\hline rs2950244 & 54143759 & & & & & & 0.95 & - & $1.16 \mathrm{E}-05$ \\
\hline rs55888542 & 54144297 & 10 & Brain & Neuroblastoma & Cancer & & 1.00 & - & $1.21 \mathrm{E}-05$ \\
\hline rs7549345 & 54145288 & 15 & Blood & $\begin{array}{c}\text { Acute megakaryocytic } \\
\text { leukemia cell }\end{array}$ & Cancer & & 0.65 & 0.046 & $3.10 \mathrm{E}-05$ \\
\hline rs2948044 & 54149577 & & & & & & 0.50 & 0.022 & $6.73 \mathrm{E}-04$ \\
\hline rs7518284 & 54150890 & 68 & Epithelium & Renal epithelial cell & Normal & EZH2, SUZ12, ZNF263, TCF7L2, KAP1 & 0.77 & 0.045 & $3.64 \mathrm{E}-05$ \\
\hline rs3006882 & 54152487 & & & & & & 0.95 & - & $2.53 \mathrm{E}-05$ \\
\hline rs2948042 & 54152703 & & & & & & 0.95 & - & $2.11 \mathrm{E}-05$ \\
\hline rs882879 & 54154726 & & & & & CTCF & 0.95 & - & $2.39 \mathrm{E}-05$ \\
\hline rs3013771 & 54155902 & 14 & Blood & $\begin{array}{l}\text { Chronic lymphocytic } \\
\text { leukemia cell }\end{array}$ & Cancer & $\begin{array}{c}\text { JUND, NR2F2, GATA2, MYC, POLR2A, } \\
\text { TEAD4, CCNT2, RCOR1, TAL1 }\end{array}$ & 1.00 & - & $2.60 \mathrm{E}-05$ \\
\hline rs3013770 & 54155959 & & & & & JUND, MYC, POLR2A, TEAD4, CCNT2 & 0.86 & - & 4.66E-05 \\
\hline rs3013769 & 54156323 & 10 & Brain & Neuroblastoma & Cancer & REST & 0.95 & - & 2.64E-05 \\
\hline rs3013768 & 54156434 & 10 & Brain & Neuroblastoma & Cancer & & 0.95 & - & $2.65 \mathrm{E}-05$ \\
\hline rs2948043 & 54156443 & 10 & Brain & Neuroblastoma & Cancer & & 0.95 & - & $2.65 \mathrm{E}-05$ \\
\hline rs12082358 & 54156624 & & & & & & 0.73 & - & $3.40 \mathrm{E}-05$ \\
\hline rs3013767 & 54156757 & & & & & & 0.95 & - & $2.44 \mathrm{E}-05$ \\
\hline rs72660653 & 54157283 & 9 & Blood vessel & $\begin{array}{l}\text { Aortic smooth muscle } \\
\text { cells }\end{array}$ & Normal & & 0.73 & - & $3.94 \mathrm{E}-05$ \\
\hline rs72660654 & 54157287 & 9 & Blood vessel & $\begin{array}{l}\text { Aortic smooth muscle } \\
\text { cells }\end{array}$ & Normal & & 0.73 & - & $3.94 \mathrm{E}-05$ \\
\hline rs3013766 & 54157498 & 2 & Skin & Fetal buttock fibroblast & Normal & & 0.82 & - & 2.97E-05 \\
\hline
\end{tabular}




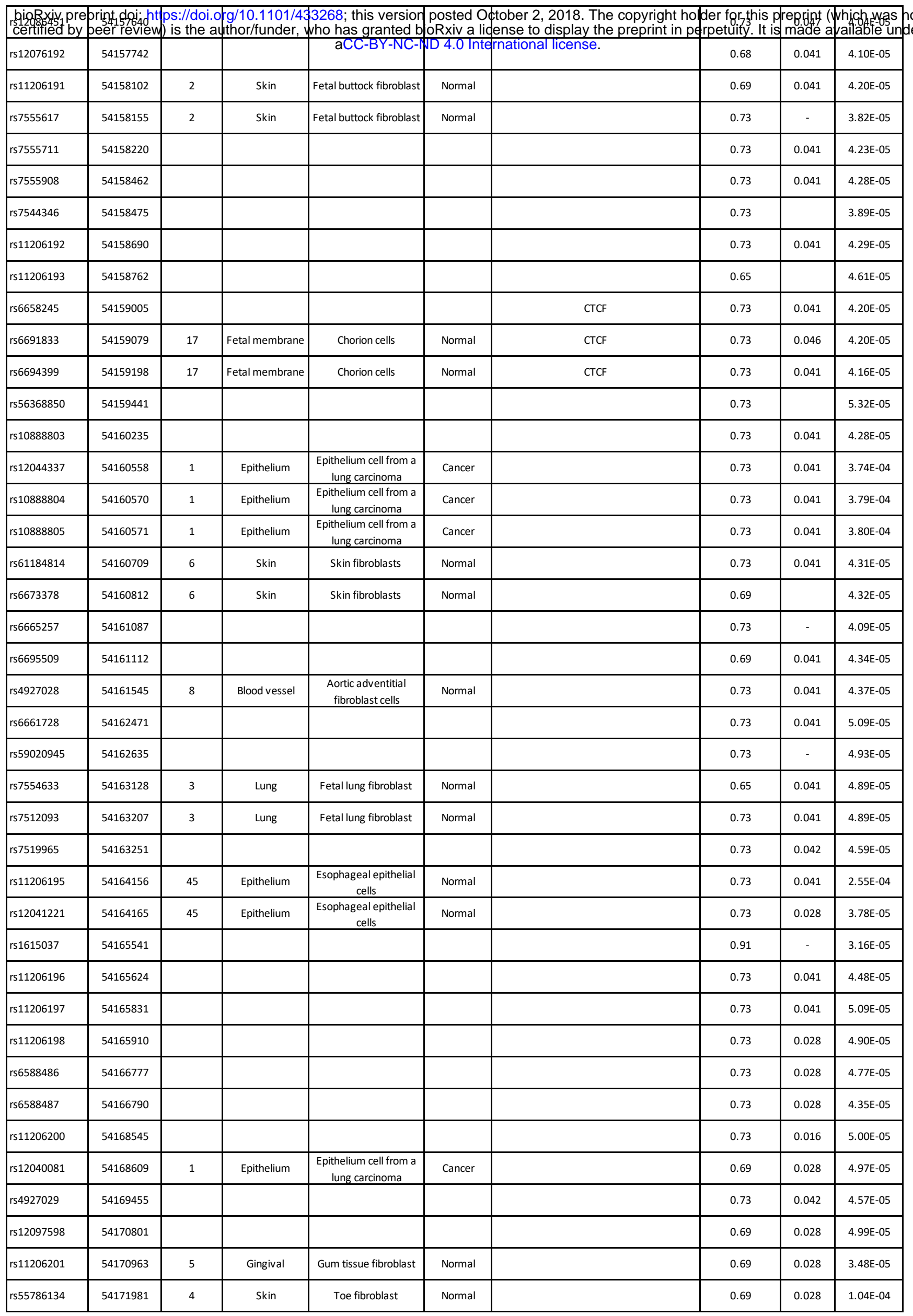




\begin{tabular}{|c|c|c|c|c|c|c|c|c|c|}
\hline rs11206202 & 54174607 & & & aCC-BY-NC- & ND 4.0 Inte & rnational license. & 0.64 & 0.034 & 2.79E-05 \\
\hline rs2694594 & 54174846 & 1 & Epithelium & $\begin{array}{l}\text { Epithelium cell from a } \\
\text { lung carcinoma tissue }\end{array}$ & Cancer & & 0.74 & - & $3.58 \mathrm{E}-05$ \\
\hline rs1780392 & 54175302 & & & & & & 0.82 & - & $3.56 \mathrm{E}-05$ \\
\hline rs12025857 & 54175360 & & & & & & 0.64 & 0.034 & $2.78 \mathrm{E}-05$ \\
\hline rs17109200 & 54175548 & 3 & Lung & Fetal lung fibroblast & Normal & & 0.64 & 0.050 & $2.54 \mathrm{E}-05$ \\
\hline rs12043690 & 54175629 & 3 & Lung & Fetal lung fibroblast & Normal & & 0.64 & 0.034 & $2.78 \mathrm{E}-05$ \\
\hline rs1879731 & 54175861 & & & & & & 0.52 & 0.034 & $2.78 \mathrm{E}-05$ \\
\hline rs1879732 & 54175909 & & & & & & 0.64 & 0.034 & $2.78 \mathrm{E}-05$ \\
\hline rs1879733 & 54175971 & & & & & & 0.64 & 0.034 & $2.78 \mathrm{E}-05$ \\
\hline rs7539908 & 54177279 & & & & & & 0.73 & - & $7.54 \mathrm{E}-05$ \\
\hline rs1780391 & 54177708 & 1 & Epithelium & $\begin{array}{l}\text { Epithelium cell from a } \\
\text { lung carcinoma }\end{array}$ & Cancer & & 0.82 & - & 3.57E-05 \\
\hline rs12080903 & 54178270 & 9 & Blood vessel & $\begin{array}{c}\begin{array}{c}\text { Aortic smooth muscle } \\
\text { cells }\end{array} \\
\end{array}$ & Normal & & 0.64 & 0.050 & $2.59 \mathrm{E}-05$ \\
\hline rs12080993 & 54178501 & & & & & & 0.64 & 0.050 & $2.59 \mathrm{E}-05$ \\
\hline rs2186041 & 54180287 & & & & & & 0.64 & 0.042 & $2.76 \mathrm{E}-05$ \\
\hline rs1614395 & 54181668 & 3 & Lung & Fetal lung fibroblast & Normal & & 0.78 & - & 3.87E-05 \\
\hline rs1526911 & 54181942 & & & & & & 0.64 & - & $2.65 \mathrm{E}-05$ \\
\hline rs1526910 & 54182174 & & & & & & 0.64 & - & $2.86 \mathrm{E}-05$ \\
\hline rs56087009 & 54182502 & & & & & & 0.59 & - & 2.69E-05 \\
\hline rs4927031 & 54183191 & & & & & & 0.64 & - & 2.95E-05 \\
\hline rs72660679 & 54183531 & & & & & GATA2 & 0.73 & - & $9.36 \mathrm{E}-05$ \\
\hline rs12043520 & 54184097 & & & & & CTCF & 0.64 & - & 3.03E-05 \\
\hline rs4927032 & 54186489 & & & & & & 0.73 & - & 3.07E-05 \\
\hline rs17388507 & 54187575 & & & & & & 0.73 & - & $2.88 \mathrm{E}-04$ \\
\hline rs11206211 & 54188096 & 18 & Skin & $\begin{array}{c}\text { Fibroblast from } \\
\text { parkinson's disease }\end{array}$ & Normal & & 0.64 & - & $1.03 \mathrm{E}-04$ \\
\hline rs6658137 & 54188994 & & & & & & 0.64 & - & $1.11 \mathrm{E}-04$ \\
\hline rs12059719 & 54190333 & & & & & & 0.73 & - & $1.22 \mathrm{E}-04$ \\
\hline rs12091931 & 54191103 & 61 & Epithelium & $\begin{array}{c}\text { Non-pigmentn ciliary } \\
\text { epithelial cells }\end{array}$ & Normal & $\begin{array}{c}\text { JUND, MAFF, MAFK, UBTF, MAZ, CTCF, } \\
\text { ZBTB7A, TBP }\end{array}$ & 0.64 & 0.036 & $1.32 \mathrm{E}-04$ \\
\hline rs72660683 & 54191811 & & & & & & 0.73 & - & $3.11 \mathrm{E}-04$ \\
\hline rs7554636 & 54193023 & & & & & & 0.60 & - & $1.29 \mathrm{E}-04$ \\
\hline rs910298 & 54193701 & 6 & Skin & Skin fibroblasts & Normal & & 0.73 & - & $3.76 \mathrm{E}-04$ \\
\hline rs702491 & 54194992 & 4 & Skin & Toe fibroblast & Normal & CTCF & 0.51 & - & 4.27E-03 \\
\hline rs12406120 & 54195034 & 4 & Skin & Toe fibroblast & Normal & & 0.61 & 0.032 & 4.60E-03 \\
\hline
\end{tabular}

